UNITED STATES DEPARTMENT OF THE INTERIOR

Ray Lyman Wilbur, Secretary

GEOLOGICAL SURVEY

George Otis Smith, Director

Water-Supply Paper 620

GEOLOGY AND GROUND-WATER RESOURCES

OF

WESTERN SANDOVAL COUNTY

NEW MEXIC0

BY

B. COLEMAN RENICK

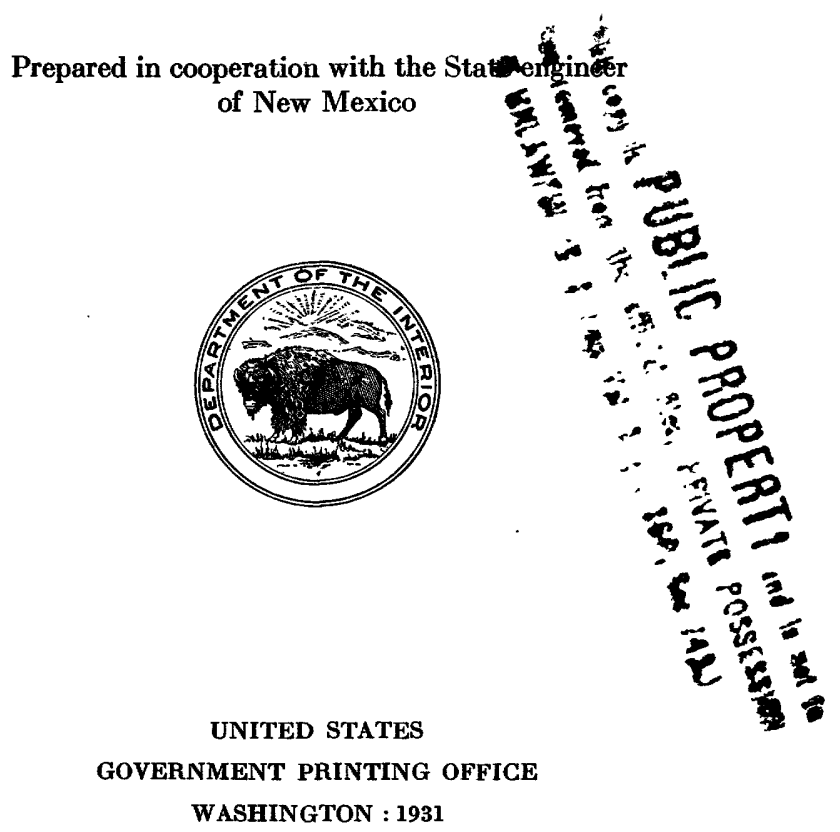

For sale by the Superintendent of Documents, Washington, D. C. - - - - Price 35 cents 



\section{CONTENTS}

Introduction

History and scope of the investigation

Acknowledgments.................... 3

Geography _...

Location and general configuration .......... 3

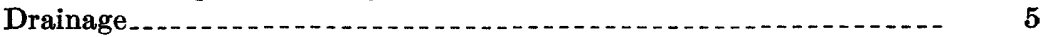

Climate................ 6

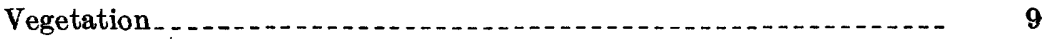

Railroads and roads

Agriculture............... 11

Inhabitants and villages.

Rock formations and their water-bearing properties.......... 12

General section.

Pre-Cambrian rocks

Carboniferous system

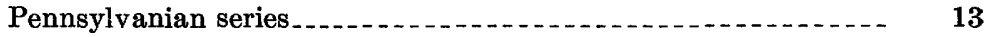

Magdalena group

Permian series.

General relations..... 17

Abo sandstone........ 18

Chupadera formation. 20

Triassic system _... 24

Poleo sandstone..... 24

Chinle (?) formation

Jurassic (?) system

Wingate sandstone.

Todilto formation

Cretaceous (?) system

Lower Cretaceous (?) series... 32

Morrison formation.

Cretaceous system.

Upper Cretaceous series. . . .

Dakota (?) sandstone........ 35

Mancos shale._.

Mesaverde formation

Lewis shale.... 49

Tertiary system

Eocene series

Puerco and Torrejon formations _... 51

Wasateh formation. 53

Miocene and Pliocene series.... 56

Santa Fe formation. 56

High-level gravel...... 58

Quaternary system..5 59

Pleistocene series.... 59

Pediments..... 59

Terraces

Water in pediment and terrace deposits.... 62 
Rock formations and their water-bearing properties-Continued.

Quaternary system-Continued.

Pleistocene and Recent series.

Page

63

Thermal spring deposits.............................. 63

Recent alluvium . . . . 63

Igneous rocks . .... . . .

Basalt. . . . . . . . . .

Santa Ana Mesa and environs. .........................

Mesa Chivato . . .

Mesa Prieta. . . . .

Peaks in the lower Rio Puerco Valley .......................

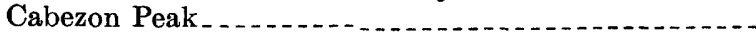

Cerro Chato .............

La Abra de los Cerros.

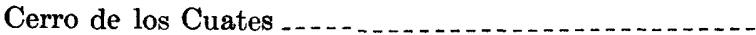

Cerro de las Chanisalas.

Cerro Cochino.........

Cerro Lopez . . . . . . . .

El Salado . . . . . .

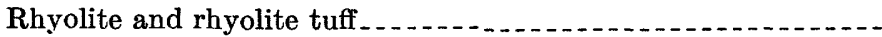

Water in the basalt and rhyolite

Structure

General features .

Faults_... 71

Sierra Nacimiento overthrust_... 71

Sierrita fault. . . . . .

Jemez fault ... . . .

Canada de las Milpas fault

Faults east of Canones .... 75

Faults at the north end of La Sierrita

Folds .

La Ventana anticline .

Olguin anticline....... 75

Cabezon anticline........ 76

Guadalupe anticline.

Rio Salado anticline............. 76

Tierra Amarilla anticline.......... 76

Canada de las Milpas anticline....................... 77

Age of deformation .............. 77

Quality of ground water.

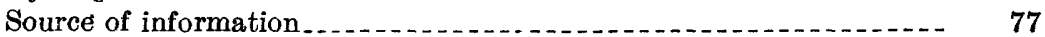

Quantity and character of dissolved solids

Relation of quality to use................ 80

Changes in chemical character of water with depth

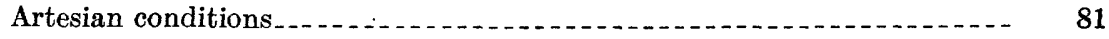

General principles ...

Areas of artesian flow....... 82

Proved areas.

Arroyo Cachana Valley

Prospective areas. . . .

San Jose-Puerco Valley . . . .

Rio Puerco south of Guadalupe... 85

Lower Rio Salado

Upper Rio Salado... . . . . . 
Artesian conditions-Continued.

Areas of artesian flow-Continued.

Prospective areas-Continued. Page

Chachulie Arroyo

Arroyo Piedra Lumbre.....

Arroyo Piedra Parada.

Canada de las Milpas.......... 86

Other prospective areas........ 86

Mineralized springs and spring deposits. . .

Indian Springs........ 86

San Ysidro Springs.

Phillips Springs_...

Source and origin of the spring waters.

Plants as indicators of ground water. 89

Surface water.

Streams

Tanks.

Descriptions of townships and land grants..................... 90

T. 23 N., R. 1 W.

T. 22 N., R. 1 W.

T. 21 N., R. 2 W.

T. 21 N., R. 1 W., including Cuba.......................... 93

T. 20 N., R. 2 W.

T. 20 N., R. 1 W.

T. 19 N., R. 2 W.

T. 19 N., R. 1 W.

T. 18 N., R. 2 W.

T. 17 N., R. 3 W

T. 17 N., R. 2 W.

T. 16 N., R. 3 W., including Cabezon........................... 102

T. 15 N., R. 3 W., including Casa Salazar.................... 102

T. 15 N., R. 2 W.................. 103

T. 15 N., R. 1 W.

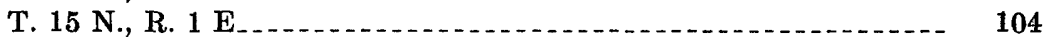

T. 14 N., R. 1 W.

T. 14 N., R. 1 E.

T. 14 N., R. 2 E.

T. 13 N., R. 3 E. .

Indian pueblo grants and reservations.

Jemez Pueblo and T. 16 N., R. 2 E.

Jemez Indian Reservation and T. 16 N., R. 1 E........... 108

Sia Pueblo and T. 15 N., R. 2 E...... 109

Santa Ana Pueblo and T. 14 N., R. 3 E............... 109

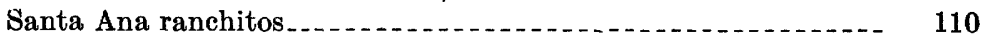

Land grants other than those made to the Indians............. 110

Ojo del Espiritu Santo grant.................. 110

San Ysidro grant....................... 112

Ignacio Chaves grant, including Guadalupe............. 113

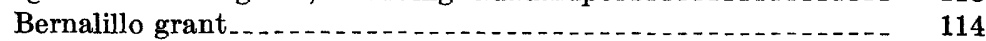

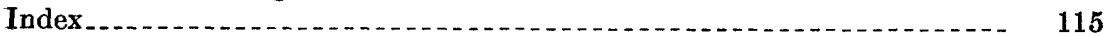




\section{ILLUSTRATIONS}

Plate 1. Geologic map and sections of the western part of Sandoval County, N. Mex . . . .

2. Map and sections showing geologic structure along the Sierra Nacimiento overthrust in T. 23 N., R. 1 W.

3. $A$, Cabezon Peak; $B$, Rhyolite tuff on Chupadera formation at the junction of San Diego and Guadalupe Canyons.........

4. $A$, Panorama from Poleo hogback southeast of La Ventana Mesa, in T. 19 N., R. 1 W.; $B$, Panorama showing structure in NE. $1 / 4$ sec. 14 and NW. 1/4 sec. 13, T. 20 N., R. 1 W....

5. $A$, Mesa Blanca; $B$, Morrison formation (lower part) in sec. 12, T. 15 N., R. $1 \mathrm{~W}$

Page

. Mesaverde formation in $\mathrm{SW} .1 / 4 \mathrm{SE} .1 / 4$ sec. $35, \mathrm{~T} .21 \mathrm{~N} ., \mathrm{R}$. 1 W.; $B$, Nacimiento group and Wasatch formation in bluff in secs. 2 and 11, T. 21 N., R. 1 W.

7. $A$, Santa Fe formation about 1 mile west of Jemez Pueblo; $B$, Todilto formation repeated by faulting near the corner of secs. 23, 24, 25, 26, T. 23 N., R. 1 W.

8. $A$, South end of Rio Salado anticline; $B$, South end of Tierra Amarilla anticline

9. Graphic representation of water analyses from western Sandoval County

10. A, Large spring near the northern part of west line of sec. 4, T. 19 N., R. 2 W.; $B$, Crater of extinct spring one-eighth of a mile north of Arroyo Penasco near Sierra Nacimiento overthrust. . . . . . . .

Fraure 1. Map of the western part of Sandoval County, N. Mex., and adjoining territory, showing area described in this paper....

2. Diagrammatic cross section showing the general relations of the Carboniferous formations along the west side of San Pedro Mountain and the Sierra Nacimiento ....................

3. Diagram showing the relations of the Mesaverde formation to the Lewis and Mancos shales.....

\section{INSERT}

Rock formations in western Sandoval County, N. Mex., and their waterbearing properties 


\title{
GEOLOGY AND GROUND-WATER RESOURCES OF WESTERN SANDOVAL COUNTY, NEW MEXICO
}

\author{
By B. Colfman Renick
}

\section{INTRODUCTION}

\section{HISTORY AND SCOPE OF THE INVESTIGATION}

In response to a request from citizens of Albuquerque and vicinity, the writer was assigned by the United States Geological Survey in 1924 to make an investigation of the ground-water conditions along Jemez Creek and the Rio Puerco, tributaries of the Rio Grande, in the western part of Sandoval County, N. Mex. About six weeks in July and August, 1924, was devoted to the field work. In a preliminary report ${ }^{1}$ it was shown that the prospects for obtaining flowing artesian wells in parts of this area were favorable. Largely on the basis of this report the State legislature of New Mexico directed the State engineer to investigate the feasibility of irrigation development, flood control, and the prospects for artesian wells in the San Jose and Rio Puerco drainage basin within Sandoval County. (S. B. No. 94; approved March 17, 1925.) The State engineer entered into a cooperative agreement with the United States Geological Survey to continue the study of the ground-water conditions in the Rio Puerco drainage basin, including the basin of the San Jose, which is a tributary of the Rio Puerco. Approximately three months in the summer and fall of 1925 was devoted to field work. On December 3, 1925, the following recommendations for testing the artesian prospects along the Rio Puerco and the Rio San Jose were submitted to the State engineer:

The field investigation pertaining to artesian water possibilities of the Rio Puerco-San Jose drainage basin, Sandoval County, N. Mex., was completed on December 3, 1925, and on the basis of this work recommendations for the drilling of three test wells are herewith made.

It will be desirable if these wells are finished at the bottom with a diameter not less than 4 inches and preferably not less than $5 \%$ inches. In all wells it will be necessary to case off the highly mineralized ground water near the surface, and it is very probable that in all the wells this can be successfully done at a depth of less than 100 feet, probably less than 50 feet. Inside of this casing it will be necessary to insert a casing of smaller diameter. This latter casing should extend to the water-bearing formation and it should either

\footnotetext{
${ }^{1}$ Renick, B. C., Ground water in Sandoval County, N. Mex. : U. S. Geol. Survey Press Mem. 18059, Dec. 26, 1924.
} 
be set in cement or attached to a packer that tightly fits against the walls of the hole. It is recommended that these wells be drilled in the order namedthat is, No. 1 first, No. 2 second, No. 3 third.

Well No. 1.-This well is to be located along the flat bordering San Jose River somewhere within the tract embracing the $\mathrm{S} .1 / 2$ sec. $31, T .22 \mathrm{~N}$, R. 1 W., and the N. $1 / 2$ sec. 6, T. 21 N., R. $1 \mathrm{~W}$. Here the basal sandstone of the Wasatch formation and the sandstones at the top of the Torrejon formation will be tested. The maximum depth recommended for this test is $\mathbf{5 0 0}$ feet. If a flow of water of sufficient magnitude to be of economic importance for irrigation is obtained at a depth less than 500 feet, the well should be finished in the formation in which the flow is obtained. If, on the other hand, small, inadequate flows are obtained at depths less than 500 feet, drilling should continue to the maximum depth or until a fiow of economic importance is obtained.

Well No.2.-In the town of Cuba the prospects for obtaining a flowing well at any depth less than 1,600 to 1,800 feet are slight, and the cost of drilling to this depth to reach the Mesaverde formation is prohibitive with the appropriation available and with success not assured. However, the prospects of obtaining ground water nearer the surface in the vicinity of Cuba should be tested, especially as the people of Cuba are very much in need of a water supply for domestic use. It is therefore recommended that a well not to exceed. 300 feet in depth be drilled in the town-on the schoolhouse property located along the main thoroughfare between the Catholic church and Young's store. If the highly mineralized ground water near the surface is effectively cased off there are good prospects of obtaining a potable water supply from a well drilled into the sand or sandstone strata near the base of the Puerco formation within a depth of $\mathbf{3 0 0}$ feet or less. Any water obtained from these strata will doubtless rise to a considerable height in the well.

Well No. 3.-This well should be located on the flat along the Rio Puerco within the tract embracing the SW. $1 / 4$ sec. 17 , SE. $1 / 4$ sec. 18, NE. $1 / 4$ NE. $1 / 4$ sec. 19 , and NW. $1 / 4$ sec. 20, T. 19 N., R. 1 W. Here the water-bearing possibility of the Mesaverde formation may be tested, and this locality is regarded as favorable for prospecting for a flowing well. The maximum depth recommended for this test is 800 feet. If a flow of water of sufficient magnitude to be of economic importance for irrigation is obtained at a depth less than 800 feet, the well should be flnished in the formation in which the flow is obtained. If, on the other hand, inadequate flows are obtained at depths less than 800 feet, drilling should be continued to the maximum depth or until a flow of economic importance is obtained.

At the time these recommendations were made two wells 'were being drilled in the area to prospect for oil-one in the vicinity of La Ventana and the other about 2 miles northwest of Sierrita Mesa. It was considered that the first well would test the artesian prospects of the Dakota (?) sandstone and the second the artesian prospects of the Poleo sandstone and underlying beds. The recommendations were therefore made with a view to testing other formations.

A small amount of additional field work was done in the summer of 1926 and a preliminary report on the geology and artesian-water prospects of the area was published in 1926 by the State engineer. ${ }^{2}$

${ }^{2}$ Renick, B. C., The geology and artesian-water prospects in the San Jose-Rio Puerco Valley in Sandoval County, N. Mex.: New Mexico State Engineer Seventh Bienn. Rept., pp. 60-75, 1926. 
The investigation was made primarily to determine the artesian prospects of the area, but considerable information was also obtained regarding means of obtaining water supplies by digging or drilling wells in areas where flowing wells are not to be expected. Settlers on the plateau west of Cuba are hampered by the lack of water supplies, and some even find it necessary to haul water many miles for domestic use. It was found that although flowing wells are not in general to be expected here, yet there are good prospects that the settlers can obtain satisfactory supplies of water for domestic and stock uses and probably also for irrigating gardens or even larger tracts.

\section{ACKNOWLEDGMENTS}

A number of persons rendered valuable help in the preparation of this report. George M. Neel, State engineer of New Mexico, cooperated by supplying all means at his disposal. O. E. Meinzer, geologist in charge of the division of ground water of the United States Geological Survey, has helped in many ways, especially in his review of the manuscript. N. H. Darton has also kindly reviewed the manuscript. H. B. Riffenburg, formerly of the Geological Survey, made the water analyses. S. Zambrano, of Cuba, by his familiarity with the location of section corners and land lines, rendered valuable assistance during much of the work in 1925. Many other residents of the region cooperated in various ways, particularly W. J. Miller, of San Ysidro; Sidney Weil, of Albuquerque; Charles Clay, of Jemez Springs; John Young, of Cuba; and Hugh M. Bryan, of Albuquerque and Cuba.

\section{GEOGRAPHY}

\section{LOCATION AND GENERAL CONFIGURATION}

The area described in this report covers about 1,150 square miles in the western part of Sandoval County. (See fig. 1.) In the northern part of the area there is a mountain range of considerable extent, the northern part of which is known as San Pedrg Mountain and the southern part as the Sierra Nacimiento. West and southwest of this mountain range is a rugged plateau characterized by many mesas and buttes. South of the mountains the country is more open and less dissected. The mountainous northern part of the area is included in the Southern Rocky Mountain province. The country west of the mountains is part of the San Juan Basin, in the Colorado Plateau province; the southern part of the area, which lies in the intermontane valley between the Sierra Nacimiento and the Sandia Mountains, is included in the Basin and Range province. 


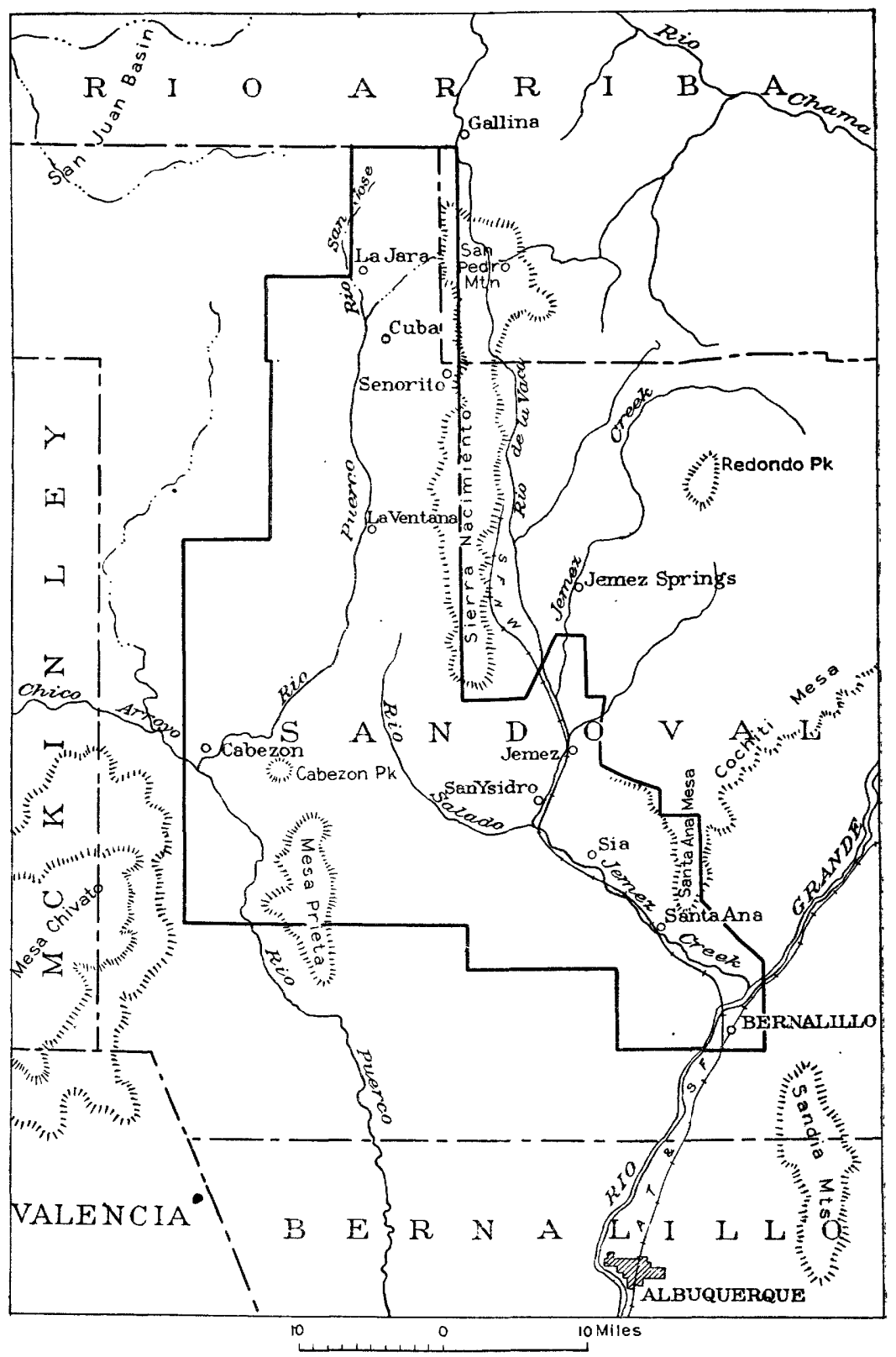

Figure 1.-Map of the western part of Sandoval County, N. Mex., and adjoining territory, showing area described in this paper (Indicated by solid line) 
The Sierra Nacimiento is defined on the east by the Rio de la Vaca, a tributary to Jemez Creek. This range is sharp crested. In its southern part the highest peaks are about 9,000 feet above sea level, and toward the north a few attain 9,200 feet. The summit of San Pedro Mountain is comparatively flat but has an altitude of about 10,600 feet. The core of the Sierra Nacimiento consists of granite, and the younger sedimentary rocks are turned up along its western flank. The plateau to the east is underlain by eruptive rocks.

The San Juan Basin is an extensive, somewhat dissected plain that occupies a part of northwestern New Mexico and southwestern Colorado. The sedimentary formations underlying the basin crop out around the margin and dip toward the center. Along the northern, eastern, and western border they are sharply upturned.' This basin is bounded on the east by the Sierra Nacimiento-San Pedro uplift, on the west by the Great Hogback, and on the north by another sharp hogback in the vicinity of Durango. On the south is the Zuni uplift, but the dip from this uplift is more gentle than on the other sides. Only the eastern part of this synclinal basin is included in the present report.

A number of mesas and buttes form conspicuous landmarks near the southeastern margin of the San Juan Basin. These are all erosion remnants. The Mesa Prieta, which lies in Tps. 13, 14, and $15 \mathrm{~N}$., R. $2 \mathrm{~W}$., is about 12 miles long and 3 to 6 miles wide. It owes its existence to the presence of a resistant cover of basalt, which has protected it from erosion. This basalt ranges in thickness from 50 to 200 feet and forms part of a lava flow that may have been once continuous with that of the Mesa Chivato. The valley of the Rio Puerco separates these two mesas. The basalt that caps the Mesa Prieta is described on page 65.

Along the Rio Puerco in the vicinity of Cabezon there are a number of peaks, the best known of which are Cabezon Peak, Cerro Chato, Cerro Cochino, La Abra de los Cerros, Cerro de los Cuates, Cerro de las Chanisalas, Cerro Lopez, and El Salado. These peaks are described on pages $66-69$.

\section{DRAINAGE}

The Rio Grande crosses the southeast corner of the area covered by this report, and nearly all of the area is drained by its tributaries. The Continental Divide is in the extreme northwest corner. The largest tributaries are the Rio Puerco and Jemez Creek. The Rio San Jose is the principal headwater tributary of the Rio Puerco, and the Rio Salado is the largest tributary of Jemez Creek. (See pl. 1.) These streams, though they carry little water during dry seasons, are properly regarded as perennial streams, but the smaller 
tributaries of the Rio Puerco, Rio Salado, and Jemez Creek, which are discussed more fully in the township descriptions, include perennial, intermittent, and ephemeral streams.

\section{CLIMATE}

The western part of Sandoval County lies in the arid or semiarid part of the United States. There is considerable variation in climate within the area, owing to the range in altitude from about 5,100 feet at Bernalillo, on the Rio Grande, to about 10,500 feet at the summit of San Pedro Mountain. The records given in the following table show that the amount of precipitation increases with the altitude. Thus the mean annual precipitation at Albuquerque (altitude 5,100 feet) is 7.84 inches; at Bernalillo (5,260 feet), 8.45 inches; at Jemez Springs (6,100 feet), 18.47 inches; at Regina (7,450 feet), 18.00 inches; near Senorito ( 8,000 feet), 22.26 inches. The amount of precipitation is influenced also by the nearness of the mountains. Jemez Springs, which is in the mountains at an altitude of 6,100 feet, has a mean annual precipitation of 18.47 inches, while Haynes, away from the mountains, in the central part of the San Juan Basin, at an altitude of 6,600 feet, has a mean annual precipitation of only 11.51 inches.

The average annual snowfall also increases with increase in altitude, being only 7.1 inches at Albuquerque and 114.7 inches near Senorito on the west slope of the mountains. The average length of the growing season at Bernalillo is 190 days, but at Senorito it is only 74 days.

Precipitation, in inches, in or near Sandoval County, N. Mex.

[U. S. Weather Bureau]

Albuquerque, Bernalillo County

[Altitude, 5,100 feet]

\begin{tabular}{|c|c|c|c|c|c|c|c|c|c|c|c|c|c|}
\hline & 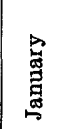 & 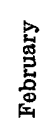 & $\begin{array}{l}\text { 总 } \\
\text { 总 }\end{array}$ & 营 & 龸 & $\stackrel{g}{g}$ & $\stackrel{\vec{g}}{\vec{g}}$ & $\begin{array}{l}\overrightarrow{0} \\
\vec{z} \\
\vec{z}\end{array}$ & 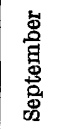 & 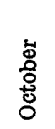 & 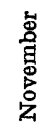 & 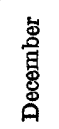 & $\begin{array}{l}\text { 焉 } \\
\text { 䙷 }\end{array}$ \\
\hline $\begin{array}{l}1850 \\
1851\end{array}$ & $\begin{array}{r}0.32 \\
.07\end{array}$ & $\begin{array}{r}0.05 \\
.56\end{array}$ & $\begin{array}{r}0.01 \\
.42\end{array}$ & $\begin{array}{r}0.02 \\
.04\end{array}$ & $\begin{array}{l}0.21 \\
.03\end{array}$ & $\begin{array}{l}0.18 \\
.00\end{array}$ & $\begin{array}{r}1.26 \\
.30\end{array}$ & 0.45 & 0.51 & 0.28 & 1.02 & 0.61 & 4.92 \\
\hline 852 & & & & .70 & .07 & 8.15 & .07 & 4. 06 & .19 & .35 & .16 & .02 & \\
\hline 1853 & .00 & .00 & .01 & .00 & .04 & .00 & 2.57 & 3.80 & .07 & .00 & .31 & .30 & 7.10 \\
\hline & .13 & .00 & .43 & .39 & 1.19 & .28 & 2.59 & 1.19 & 2.67 & 1.37 & 1.35 & .92 & 12.51 \\
\hline $\begin{array}{l}1855- \\
1856 \text {. }\end{array}$ & $\begin{array}{l}.20 \\
.20\end{array}$ & $\begin{array}{l}.40 \\
.20\end{array}$ & $\begin{array}{r}1.02 \\
.19\end{array}$ & $\begin{array}{l}.74 \\
.10\end{array}$ & $\begin{array}{l}.89 \\
.23\end{array}$ & .25 & .17 & 1.23 & 1.12 & .10 & $\begin{array}{l}.77 \\
.33\end{array}$ & .03 & 4.15 \\
\hline 1857 . & 1.45 & .25 & .00 & .15 & .00 & .10 & .35 & .77 & .78 & 1.25 & .10 & .00 & 5.20 \\
\hline n. & .00 & .50 & .80 & 1. 60 & .00 & 3. 50 & 3.60 & 4.90 & $\therefore 00$ & .00 & .00 & 1.40 & 16.30 \\
\hline$\ldots$ & .00 & .00 & .15 & .15 & .00 & .00 & .25 & 2.30 & 3.10 & .00 & .00 & .00 & 5.95 \\
\hline 1860 & .70 & .30 & .00 & .00 & & .70 & .20 & 1.00 & .35 & .00 & .52 & .01 & 3.78 \\
\hline - & - & .00 & & & & & & & & $2 n$ & .00 & 19 & $=$ \\
\hline 1864 . & .37 & .00 & Tr. & Tr. & 10 & 1.84 & .90 & .25 & .30 & .67 & .52 & .59 & 5.54 \\
\hline 1865 . & .20 & .39 & .10 & .20 & .19 & 1.45 & 1.00 & 1.30 & .00 & 5.40 & .00 & .12 & 10.35 \\
\hline 1867 & .20 & .10 & & & & & & $\ldots$ & .90 &. .32 & .17 & & - \\
\hline 1878 & .45 & .16 & .02 & .02 & & & .41 & & & .00 & 1.83 & .07 & \\
\hline $1879-$ & .49 & .26 & .02 & .02 & .03 & Tr. & $\cdots$ & & & & & & . \\
\hline $81 \ldots$ & & & & & & & & & & & & & \\
\hline
\end{tabular}


Precipitation, in inches, in or near Sandoval County, N. Mex.-Continued

Albuquerque, Bernalillo County-Continued

\begin{tabular}{|c|c|c|c|c|c|c|c|c|c|c|c|c|c|}
\hline & 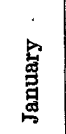 & 䓫 & 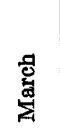 & 壳 & $\stackrel{\overrightarrow{\mathrm{a}}}{\mathrm{a}}$ & 㤩 & $\vec{B}$ & 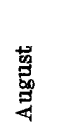 & 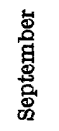 & 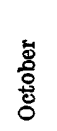 & 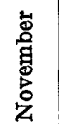 & 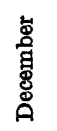 & 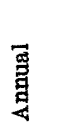 \\
\hline & & & & 0.70 & $\begin{array}{c}\text { Tr. } \\
0.04\end{array}$ & $\begin{array}{r}0.53 \\
.00\end{array}$ & $\begin{array}{l}0.77 \\
2.07\end{array}$ & $\begin{array}{r}0.21 \\
.61\end{array}$ & $\begin{array}{r}0.18 \\
.97\end{array}$ & $\begin{array}{r}0.76 \\
.15\end{array}$ & 0.00 & & \\
\hline & 0.81 & 0.84 & 0.81 & .20 & .12 & .08 & 1.45 & .21 & Tr. & 2.21 & .00 & $\begin{array}{r}0.02 \\
.11\end{array}$ & 6.84 \\
\hline 3 & .31 & .07 & $\begin{array}{r}.22 \\
.10\end{array}$ & Tr. & .45 & Tr. & 1.27 & 1.88 & 2.95 & .09 & 17 & 01 & $\begin{array}{l}0.04 \\
7.42\end{array}$ \\
\hline 4. & $\begin{array}{r}.01 \\
1.29\end{array}$ & $\begin{array}{r}.31 \\
.60\end{array}$ & $\begin{array}{l}.18 \\
.07\end{array}$ & $\begin{array}{r}.60 \\
08\end{array}$ & $\begin{array}{r}.80 \\
1.73\end{array}$ & $\begin{array}{r}.03 \\
. \quad 34\end{array}$ & $\begin{array}{r}42 \\
278\end{array}$ & $\begin{array}{r}2.25 \\
80\end{array}$ & $\begin{array}{r}.32 \\
18\end{array}$ & $\begin{array}{r}.49 \\
.74\end{array}$ & $\operatorname{Tr}$. & .31 & $\begin{array}{l}5.72 \\
978\end{array}$ \\
\hline & .06 & .07 & .01 & Tr. & .07 & $\begin{array}{r}.04 \\
.32\end{array}$ & 1.98 & .81 & .70 & 2.55 & .05 & 38 & $\begin{array}{l}7.10 \\
7.02\end{array}$ \\
\hline 97. & .57 & .13 & .72 & .63 & 2.07 & .99 & .31 & 1.31 & 1.22 & 1.44 & Tr. & .35 & 9.74 \\
\hline 1898 - & .58 & .54 & .34 & .33 & .12 & 1.00 & 1.25 & .60 & .28 & .15 & .50 & .70 & 6.39 \\
\hline 99 & .35 & .35 & .40 & .34 & .00 & .44 & 3.23 & .63 & 1. 20 & Tr. & .20 & .02 & 7. 16 \\
\hline 1900 & .70 & .40 & .13 & .33 & .85 & .06 & 13 & .13 & 2. 09 & .25 & .83 & Tr. & 5.90 \\
\hline 1901 & .65 & 69 & 15 & .31 & .55 & .30 & 1.46 & 1.85 & 1.21 & 2. 00 & 1.03 & $\operatorname{Tr}$. & 10.19 \\
\hline 1902 & .32 & Tr. & Tr. & .00 & .23 & Tr. & 1.20 & .70 & .55 & Tr. & 1.10 & .84 & 4.94 \\
\hline 1903 & .08 & .41 & .38 & .05 & .18 & 2.48 & .32 & .00 & 1.93 & .00 & .00 & .00 & \\
\hline 1904 & .20 & .10 & Tr. & Tr. & 1.19 & .32 & .94 & 1.88 & 1.42 & .17 & .00 & .60 & 6.82 \\
\hline - & 1.00 & Tr. & Tr. & 4. 20 & .00 & 1.37 & & .72 & .59 & .00 & 4.70 & 2.93 & 15. 73 \\
\hline 1906 & .20 & Tr. & .30 & 1.05 & .05 & .06 & 1.93 & .85 & 1.80 & .52 & .40 & 1. 20 & \\
\hline 1907 & .37 & .00 & .00 & 2.50 & 1.42 & .18 & .93 & 1.66 & .20 & 1.50 & .42 & .01 & 9.19 \\
\hline & .42 & .34 & .00 & 2.09 & .34 & .28 & 1.5 & 1.75 & .37 & .2 & .04 & .24 & 7.61 \\
\hline 1909 & .37 & .17 & .11 & .12 & .16 & .12 & .85 & 1. 56 & .52 & .0 & .25 & .19 & 4.42 \\
\hline & .14 & .31 & .30 & .55 & .63 & .79 & 1.8 & 1.51 & .06 & .29 & .73 & .22 & 7.41 \\
\hline & .33 & 1.73 & .42 & .28 & .28 & 1. 26 & 2. & .62 & 1.04 & 3.30 & .34 & .20 & 11.94 \\
\hline & .02 & .19 & .74 & .13 & .30 & .64 & 2. 39 & .6 & .29 & .29 & .00 & .47 & 6.09 \\
\hline 1012 & .78 & .41 & .15 & .44 & .24 & .99 & .46 & .59 & .55 & .31 & .69 & 1.06 & 6. 67 \\
\hline 15 & $\begin{array}{r}.02 \\
.68\end{array}$ & $\cdot 40$ & .40 & 884 & 1.02 & .14 & 2. 01 & 2. 00 & .20 & 1.93 & .00 & 2.43 & 11.39 \\
\hline & $\begin{array}{r}.08 \\
2.52\end{array}$ & & & & & & & $\begin{array}{r}.85 \\
1.95\end{array}$ & $\begin{array}{r}1.18 \\
.34\end{array}$ & 2.77 & .00 & Tr. & 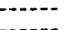 \\
\hline & .35 & .73 & Tr. & .12 & .50 & .18 & .25 & & .60 & $\mathrm{Tr}$. & Tr. & .00 & 3.29 \\
\hline & .29 & .31 & .98 & .33 & .49 & .34 & .95 & 1.46 & .15 & 1.79 & .24 & .30 & 7. 63 \\
\hline & Tr. & .13 & 1.25 & 1.93 & 1.34 & .84 & 4.12 & .8 & 1. 36 & 1.61 & .68 & .79 & 15. 03 \\
\hline & .04 & .30 & .43 & .38 & 1.07 & .67 & .15 & 1.50 & .29 & 1. 12 &, 08 & .23 & 6.26 \\
\hline & .12 & .18 & .86 & Tr. & .28 & 2.46 & 2.77 & 2.60 & .37 & .37 & .00 & .28 & 10.29 \\
\hline [ean ... & .41 & .30 & .29 & .55 & .43 & .76 & 1.31 & 1. 30 & .78 & .84 & .44 & .43 & 14.8 \\
\hline
\end{tabular}

Bernalillo, Sandoval County

[Altitude, 5,260 feet]

\begin{tabular}{|c|c|c|c|c|c|c|c|c|c|c|c|c|c|}
\hline \multicolumn{14}{|l|}{1889} \\
\hline 1890 & & 1.00 & 1.30 & 1.00 & & & 1.10 & 1.20 & 1.50 & 0.50 & 0.60 & 2.00 & \\
\hline 1891 & 1.00 & .70 & 1.60 & .00 & 2.00 & 0.00 & .20 & .10 & 2.80 & .00 & .00 & .50 & 8.90 \\
\hline 1892 & 1.00 & 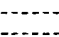 & $-\infty$ & $n-1$ & 1.76 & .22 & 2.55 & 1,54 & .02 & 1.05 & 1.20 & .21 & \\
\hline 1896 . & .01 & $\mathrm{Tr}$ & .00 & .00 & Tr. & .62 & $\begin{array}{r}.80 \\
.80\end{array}$ & 1. 17 & 1.37 & 3. 71 & Tr. & .21 & 7.89 \\
\hline $1897 \ldots$ & .28 & $\operatorname{Tr}$. & .68 & .55 & 2. 23 & .63 & .69 & .47 & 4.02 & 1.77 & .10 & .07 & 11. 49 \\
\hline 1898 & .52 & .48 & .37 & .57 & .02 & .41 & .90 & 1.38 & Tr. & .12 & .30 & .75 & 5.82 \\
\hline 1899 & .15 & Tr. & .20 & 10 & .00 & .42 & 3. 21 & .64 & 1.70 & Tr. & .45 & .02 & 6.89 \\
\hline $2-10-2-10-2$ & .55 & .16 & .16 & .45 & .37 & .14 & .75 & .34 & 1.68 & .58 & .39 & .07 & 5. 50 \\
\hline 91 _ ב & .93 & .36 & .40 & .17 & .66 & $---n$ & 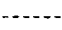 & & $-n$ & & $-\ldots$ &.-- & -- \\
\hline Mean & .56 & .28 & .49 & .26 & .88 & .35 & 1. 30 & .86 & 1. 64 & .97 & .38 & .48 & 8. 45 \\
\hline
\end{tabular}

\section{Haynes, Rio Arriba County}

[Altitude 6,600 feet]

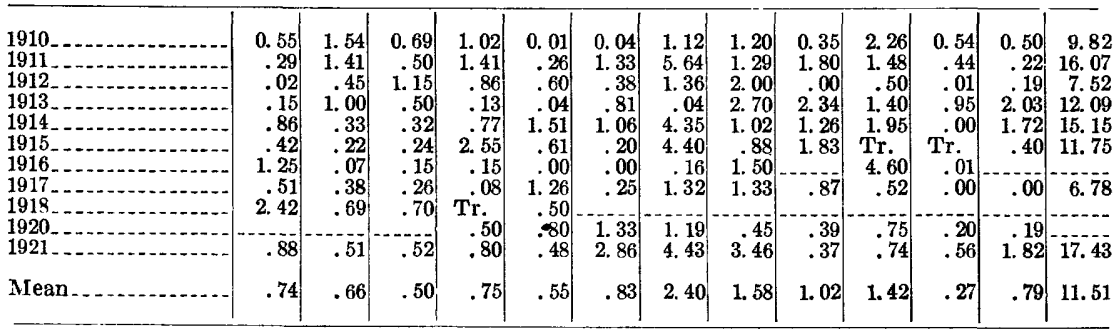


Precipitation, in inches, in or near Sandoval County, N. Mex.-Continued

\section{Jemez Springs, Sandoval County}

[Altitude 6,100 feet]

\begin{tabular}{|c|c|c|c|c|c|c|c|c|c|c|c|c|c|}
\hline $\begin{array}{l}1910 \\
1911 \\
1912 \\
1913 \\
1914 \\
1915 \\
1916 \\
1917 \\
1918 \\
1919 \\
1920 \\
1921\end{array}$ & $\begin{array}{r}0.81 \\
\text { Tr. } \\
.80 \\
.90 \\
1.41 \\
5.12 \\
1.39 \\
1.66 \\
.10 \\
1.29 \\
.88\end{array}$ & $\begin{array}{r}2.51 \\
.40 \\
1.60 \\
.47 \\
1.13 \\
.54 \\
.85 \\
1.59 \\
1.31 \\
1.33 \\
.70\end{array}$ & $\begin{array}{r}0.75 \\
2.36 \\
.73 \\
.02 \\
.79 \\
2.12 \\
.08 \\
1.07 \\
2.62 \\
1.15 \\
.38\end{array}$ & $\begin{array}{r}0.47 \\
1.15 \\
1.57 \\
.89 \\
4.32 \\
2.15 \\
.12 \\
.97 \\
2.28 \\
1.41 \\
.17\end{array}$ & $\begin{array}{r}0.25 \\
.87 \\
.33 \\
.04 \\
2.03 \\
1.77 \\
.37 \\
2.10 \\
.05 \\
2.90 \\
1.90 \\
1.60\end{array}$ & $\begin{array}{l}0.55 \\
1.83 \\
3.01 \\
3.77 \\
1.99 \\
1.06 \\
\text { Tr. } \\
\text { Tr. } \\
1.70 \\
1.66 \\
1.16 \\
3.69\end{array}$ & $\begin{array}{l}\text { 3. } 34 \\
\text { 4. } 80 \\
\text { 3. } 53 \\
.66 \\
\text { 3. } 88 \\
\text { 4. } 77 \\
\text { 3. } 45 \\
\text { 2. } 23 \\
\text { 3. } 14 \\
6.04 \\
1.56 \\
\text { 5. } 07\end{array}$ & $\begin{array}{l}2.17 \\
1.68 \\
2.01 \\
2.09 \\
5.30 \\
2.30 \\
4.55 \\
.97 \\
1.88 \\
1.71 \\
2.73 \\
2.40\end{array}$ & $\begin{array}{r}0.36 \\
2.10 \\
.34 \\
1.85 \\
.76 \\
1.75 \\
.62 \\
1.41 \\
.72 \\
1.60 \\
.26 \\
.05\end{array}$ & $\begin{array}{r}1.96 \\
5.19 \\
1.05 \\
.08 \\
\text { 3. } 24 \\
.18 \\
3.72 \\
.10 \\
2.29 \\
2.05 \\
2.42 \\
.54\end{array}$ & $\begin{array}{l}1.42 \\
2.02 \\
\mathrm{Tr} . \\
2.08 \\
\mathrm{Tr} . \\
.40 \\
\mathrm{Tr} . \\
\mathrm{Tr} . \\
1.53 \\
1.03 \\
\dot{\mathrm{Tr}} .\end{array}$ & $\begin{array}{r}0.62 \\
.22 \\
.40 \\
1.98 \\
2.28 \\
1.34 \\
.32 \\
.00 \\
1.88 \\
.99 \\
.65 \\
1.34\end{array}$ & $\begin{array}{r}23.25 \\
14.58 \\
17.25 \\
21.76 \\
21.22 \\
22.96 \\
9.25 \\
18.48 \\
24.29 \\
16.28 \\
16.82\end{array}$ \\
\hline Mean & 1. 31 & 1.13 & 1. 10 & 1.41 & 1. 18 & 1. 70 & 3. 54 & 2. 48 & .98 & 1. 90 & .74 & 1.00 & 18. 47 \\
\hline
\end{tabular}

\section{Regina, Sandoval County}

[Altitude, 7,450 feet]

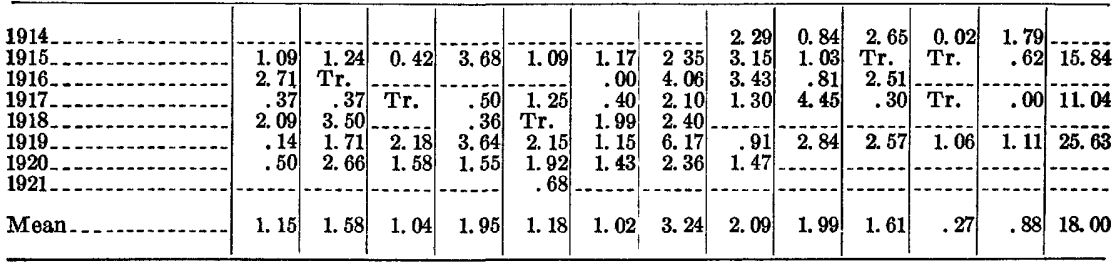

\section{Near Senorito, Sandoval County}

[Altitude 8,000 feet]

\begin{tabular}{|c|c|c|c|c|c|c|c|c|c|c|c|c|c|}
\hline 21 & & & & & & 1. 65 & 2. 29 & 2. 58 & 0.15 & 0. 63 & 0.37 & 0.46 & \\
\hline 1913 & 0.74 & 1.54 & 0.97 & 1. 17 & 0.19 & 5.81 & 2. 18 & 2.05 & 2. 8.5 & 1. 07 & 2. 08 & 3.12 & 23.17 \\
\hline 14 & .90 & .43 & .78 & 1.05 & 2. 40 & .68 & 5. 96 & 3.01 & 1. 27 & 2.95 & .00 & 2.30 & 21. 73 \\
\hline & 1. 65 & 1. 78 & 1. 07 & 4. 64 & 1.75 & 1. 20 & 3. 67 & 3. 15 & 1.91 & Tr. & .64 & 1.65 & 23. 11 \\
\hline - & 6. 45 & .85 & 2. 22 & 1.83 & .62 & .01 & 5. 04 & 5.08 & .91 & 3. 21 & & .65 & 26.91 \\
\hline & 1. 38 & .50 & .34 & .80 & 1.87 & .15 & 3.83 & 1.28 & 2.08 & .00 & Tr. & .00 & 13. 13 \\
\hline - & 2. 05 & 3.11 & 2. 62 & .93 & .36 & 1. 49 & 2. 51 & 1. 40 & .40 & 1. 68 & 1.91 & 2.00 & 20.46 \\
\hline - & .15 & 2. 32 & 2. 97 & 3. 41 & 3.17 & 3.27 & 7.02 & 1.64 & 1.16 & 2. 79 & 1.52 & 1.81 & 31. 23 \\
\hline & 1. 87 & 2.60 & 2. 18 & 1. 75 & 2. 56 & 1. 35 & 2. 37 & 1. 43 & 1. 47 & 2.54 & & 1. 53 & 22. 10 \\
\hline & 1. 42 & 1. 11 & 1. 15 & .61 & & 3.41 & 9. 1 & 2.5 & .76 & 1.31 & Tr. & 1. 97 & 23. 12 \\
\hline Mean & 1.85 & 1.58 & 1. 59 & 1.80 & 1. 46 & 1.90 & 4.40 & 2.42 & 1.39 & 1. 62 & .70 & 1. 55 & 22.26 \\
\hline
\end{tabular}

Average snowfall, in inches, in or near Sandoval County, N. Mex.

\begin{tabular}{|c|c|c|c|c|c|c|c|c|c|c|c|c|c|c|c|}
\hline Station & 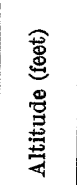 & 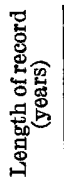 & 宓 & 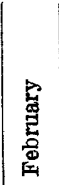 & $\begin{array}{l}\text { 률 } \\
\text { 荧 }\end{array}$ & 离 & 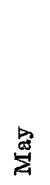 & 曋 & $\stackrel{\vec{B}}{\overrightarrow{3}}$ & 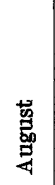 & 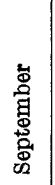 & 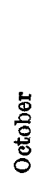 & 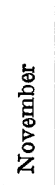 & 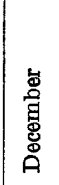 & 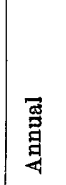 \\
\hline $\begin{array}{l}\text { Albuquerque } \\
\text { Jemez Springs } \\
\text { Regina } \\
\text { Senorito (near) }\end{array}$ & $\begin{array}{l}5,100 \\
6,100 \\
7,450 \\
8,000\end{array}$ & $\begin{array}{r}25 \\
12 \\
5 \\
9\end{array}$ & $\begin{array}{r}1.8 \\
9.8 \\
14.0 \\
27.1\end{array}$ & $\begin{array}{r}1.7 \\
9.8 \\
9.4 \\
17.5\end{array}$ & $\begin{array}{r}0.6 \\
5.7 \\
7.1 \\
17.3\end{array}$ & $\begin{array}{r}0.1 \\
3.4 \\
8.0 \\
14.7\end{array}$ & $\begin{array}{l}0.0 \\
.4 \\
1.5 \\
6.2\end{array}$ & $\begin{array}{l}0.0 \\
.0 \\
.0 \\
.4\end{array}$ & $\begin{array}{r}0.0 \\
.0 \\
.0 \\
.0\end{array}$ & $\begin{array}{l}0.0 \\
.0 \\
.0 \\
.0\end{array}$ & $\begin{array}{r}0.0 \\
\dot{\mathrm{T} r} . \\
.3\end{array}$ & $\begin{array}{l}0.2 \\
1.0 \\
\text { Tr. } \\
2.6\end{array}$ & $\begin{array}{l}0.5 \\
3.6 \\
.1 \\
6.1\end{array}$ & $\begin{array}{r}2.2 \\
8.9 \\
7.5 \\
22.5\end{array}$ & $\begin{array}{r}7.1 \\
42.7 \\
47.6 \\
114.7\end{array}$ \\
\hline
\end{tabular}


Mean temperature, in ${ }^{\circ} F$., in or near Sandoval County, N. Mex.

\begin{tabular}{|c|c|c|c|c|c|c|c|c|c|c|c|c|c|c|c|}
\hline Station & 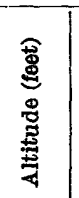 & 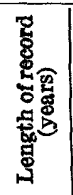 & 曾 & 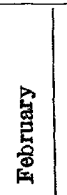 & $\begin{array}{l}\text { 总 } \\
\text { 荥 }\end{array}$ & 芯 & 公 & 兽 & 坣 & 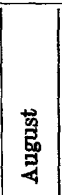 & 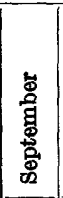 & $\begin{array}{l}\text { 峞 } \\
\frac{8}{8} \\
8 .\end{array}$ & 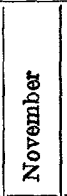 & 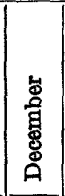 & 尊 \\
\hline $\begin{array}{l}\text { Albuquerque..... } \\
\text { Jemez Spring.... } \\
\text { Haynes } \\
\text { Senorito (near) }\end{array}$ & $\begin{array}{l}5,100 \\
6,100 \\
6,600 \\
8,000\end{array}$ & $\begin{array}{r}21 \\
11 \\
9 \\
9\end{array}$ & $\begin{array}{l}35.2 \\
31.2 \\
23.0 \\
21.4\end{array}$ & $\begin{array}{l}40.3 \\
35.1 \\
28.8 \\
24.2\end{array}$ & $\begin{array}{l}48 \\
41.3 \\
36.6 \\
30.4\end{array}$ & $\begin{array}{l}55.4 \\
48.0 \\
42.6 \\
39.0\end{array}$ & $\begin{array}{l}63.7 \\
56.1 \\
52.8 \\
46.2\end{array}$ & $\begin{array}{l}73 \\
65.1 \\
63.2 \\
55.2\end{array}$ & $\mid \begin{array}{l}76 \\
68.7 \\
68.6 \\
59.6\end{array}$ & $\begin{array}{l}74.2 \\
67.6 \\
66.8 \\
57.8\end{array}$ & $\begin{array}{l}67.7 \\
61.5 \\
59.5 \\
51.4\end{array}$ & $\begin{array}{l}56.2 \\
51.2 \\
48.2 \\
41.3\end{array}$ & $\begin{array}{l}44.0 \\
41.2 \\
36.7 \\
32.5\end{array}$ & $\begin{array}{r}35.2 \\
31.6 \\
23.6 \\
23.1\end{array}$ & $\begin{array}{l}255 . \\
6.49 . \\
6.5 . \\
10 .\end{array}$ \\
\hline
\end{tabular}

Occurrence of frost and length of growing season in or near Sandoval County, N. Mex.

\begin{tabular}{|c|c|c|c|c|c|c|c|}
\hline Station & $\underset{\text { (feet) }}{\text { Altitude }}$ & $\begin{array}{l}\text { Length } \\
\text { of } \\
\text { record } \\
\text { (years) }\end{array}$ & $\begin{array}{l}\text { Latest } \\
\text { killing } \\
\text { frost in } \\
\text { spring }\end{array}$ & $\begin{array}{l}\text { Earliest } \\
\text { killing } \\
\text { frost in } \\
\text { autumn }\end{array}$ & $\begin{array}{l}\text { Average } \\
\text { date of } \\
\text { lass } \\
\text { killing } \\
\text { frost in } \\
\text { spring }\end{array}$ & $\begin{array}{l}\text { Average } \\
\text { date of } \\
\text { first } \\
\text { killing } \\
\text { frost in } \\
\text { autumn }\end{array}$ & $\begin{array}{l}\text { Length } \\
\text { of } \\
\text { growing } \\
\text { season } \\
\text { (days) }\end{array}$ \\
\hline 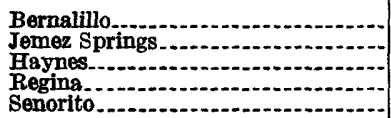 & $\begin{array}{l}5,260 \\
6,100 \\
6,600 \\
7,450 \\
8,000\end{array}$ & $\begin{array}{r}6 \\
12 \\
8 \\
6 \\
9\end{array}$ & $\begin{array}{lr}\text { May } & 13 \\
\text { June } & 2 \\
\text { May } & 27 \\
\text { June } & 7 \\
\text { July } & 28\end{array}$ & $\begin{array}{l}\text { Oct. } 16 \\
\text { Oct. } 11 \\
\text { Sept. } 10 \\
\text { Sept. 12 } \\
\text { Aug. } 28\end{array}$ & $\begin{array}{l}\text { Apr. } 18 \\
\text { May } \\
\text { May } \\
\text { May } \\
\text { June } 26 \\
\text { June }\end{array}$ & $\begin{array}{l}\text { Oct. } 25 \\
\text { Oct. } 24 \\
\text { Sept. } 22 \\
\text { Sept. } 22 \\
\text { Sept. } 9\end{array}$ & $\begin{array}{r}190 \\
170 \\
131 \\
119 \\
74\end{array}$ \\
\hline
\end{tabular}

\section{VEGETATION ${ }^{3}$}

The types of vegetation natural to the Southwest have been described by Shantz." Sandoval County contains many of these types. The most notable species are sagebrush (Artemisia sp.), grama grass (Bouteloua sp.), galleta grass (Hilaria jamesii), piñon, juniper, yellow pine (Pinus ponderosa), Douglas fir (Pseudotsuga mucronata), white fir (Abies concolor), and Engelmann spruce (Picea engelmannii).

In the open, semiarid country sagebrush predominates. It is associated with grama grass, the proportion of which is greatest in localities that have a porous soil. At a slightly higher altitude, especially on ridges that are underlain by sandstone, are abundant stands of piñon and juniper, with underbrush of grama grass and sagebrush. Above this belt, in the Sierra Nacimiento and San Pedro Mountain, western yellow pine is the principal tree; it grows on the slopes as high as 9,500 feet. The tree known as New Mexico white pine (Pinus neomexicana), which is similar to the true white pine, occurs on the drier and more exposed mountain slopes in the belt of yellow pine. Above 10,000 feet the Engelmann spruce is the principal tree, but with it is associated the cork-bark fir (Abies arizonica). Between

SThis section has been prepared largely from data furnished by Hugh M. Bryan, a rancher in the San Pedro Mountains, who was formerly with the United States Forest Service.

- Shantz, H. L., The physieal basis of agriculiture, pt. 1, Natural vegetation, sec. E.: U. S. Dept. Agr. Atlas Am. Agriculture, sheet 6, 1924. 
the pine belt and the spruce belt there is a transition zone characterized by Douglas fir and white fir. Mr. Bryan points out that in the mountains the type of vegetation is not controlled entirely by altitude but is influenced also by the presence of sunlight-for example, the south slopes between 9,000 and 10,000 feet have vegetation similar to that of the north slopes between 7,000 and 9,000 feet.

The shrubs of the mountains between 7,000 and 10,000 feet consist largely of oak, rose, service berry, elderberry, and locust.

The principal grasses below 8,000 feet are grama and galleta, but at higher altitudes there are different types. In the drier localities bunch grasses are characteristic, including mountain bunch grass (Muhlenbergia montana) and pine bunch grass (Festuca arizonica).

Locally there are plants that depend upon ground water for their existence and are therefore indicators of its presence. (See p. 89.)

\section{RAILROADS AND ROADS}

The main line of the Atchison, Topeka \& Santa Fe Railway passes along the east bank of the Rio Grande through the town of Bernalillo. The Santa Fe Northwestern Railway leads across the Rio Grande and follows Jemez Creek through San Ysidro to Guadalupe Canyon, which it ascends for 10 miles or more into the San Diego grant. This railroad was constructed by the White Pine Lumber Co. for transporting logs from the San Diego grant to the sawmill at Bernalillo. Another railroad is projected to extend from San Ysidro, where it will connect with the Santa. Fe Northwestern, to La Ventana and thence northwestward across the San Juan Basin to Farmington. At the end of the 1925 field season the roadbed for this railroad had been graded for most of the distance between San Ysidro and La Ventana, and rails had been laid on part of this stretch. This road is being built to provide communication between Farmington and Albuquerque and to assist in the development of the San Juan Basin country.

From Bernalillo a hard-surfaced road leads along the Rio Grande to Albuquerque and a gravel road leads to San Ysidro. There is a good road from San Ysidro to Jemez Springs, and in 1925 the Forest Service built a road from Sulphur Springs almost to Jemez Springs. A well-traveled road leads from San Ysidro to Cuba, but as this road crosses a number of shale formations it gets in poor condition for short periods during and after heavy rains. From Cuba an automobile road runs eastward to Senorito, and from Senorito to the summit of San Pedro Mountain there is a graded road built by the Forest Service. Northward from Cuba a fairly good road runs to Gallina and points north and east. A road by way of Haynes connects Cuba with Farmington. About 3 
miles southwest of Cuba a secondary automobile road leads to the west, and about 6 miles southeast of $\mathrm{Cuba}$ is another road that leads southwestward to Cabezon. Between La Ventana and Cabezon there is a well-traveled road, and from Cabezon one may go to Albuquerque by automobile on a road that runs east of the Mesa Prieta and southeastward across La Ceja to Corales; this is the mail route between Albuquerque, Cabezon, and Cuba.

\section{AGRICULTURE}

Much of the bottom land adjacent to the Rio Grande is irrigated with considerable success. Orchards and truck gardens àre plentiful, but the largest acreage is in alfalfa and grain. On the bottom lands of the tributaries of the Rio Puerco irrigation is practiced, and alfalfa is the principal crop. The vicinity of Cuba, especially to the west and north, is adapted to dry farming. In recent years the bean crop of this section has become of considerable importance. Potatoes are a profitable crop, and some corn is raised. The summit of San Pedro Mountain has a growing season sufficiently long for raising potatoes, hay, and grain. Along the Rio Puerco, from a point about 5 miles south of Cuba to Cabezon, little or no land is cultivated, owing chiefly to the scarcity of water. The mountain region is suitable for raising stock, especially cattle and sheep, and it also supports many wild horses.

\section{INHABITANTS AND VILLAGES}

Excluding the Indian pueblos, which are described on pages 107110 , the largest centers of population are Bernalillo, Cuba, San Ysidro, Jemez Springs, and Cabezon. The inhabitants of these communities are largely of Spanish descent.

The town of Bernalillo, which had a population of 786 in $1920,{ }^{4 a}$ is built along the Rio Grande and is on the main line of the Atchison, Topeka \& Santa Fe Railway. It has a number of general stores and several garages. The inhabitants of an extensive area to the north haul their products to Bernalillo with autotrucks or horse-drawn vehicles.

San Ysidro, at the junction of the Rio Salado and Jemez Creek, is an intermediate point for traffic from the Rio Grande bound either toward Cuba or for the Jemez Springs and Sulphur Springs country. It is a trading center for the inhabitants of the surrounding country, including the Indian pueblos of Santa Ana, Sia, and Jemez.

Jemez Springs is not only a center for the inhabitants of that vicinity but is also a summer resort, as it has a very pleasant climate and attractive natural scenery. It contains two first-class hotels

4a Bernalillo precinct had 988 in 1920 and 2,213 in 1930 . 3616-31-2 
and two bathhouses that utilize the hot mineral waters of the Jemez Springs.

La Ventana lies on the route of the projected railroad between San Ysidro and Cuba. In 1924, when the investigation was begun, it contained only one house; in 1925 coal was being mined and there was a store and several houses.

Cuba contains several general stores, a hotel, garage, schools, and other facilities. It is the center of a considerable rural population living mostly to the west and north. Cuba obtains most of its supplies from Albuquerque and Bernalillo by autotrucks.

\section{ROCK FORMATIONS AND THEIR WATER-BEARING PROPERTIES}

\section{GENERAL SECTION}

The geologic section exposed in this area is of exceptional interest, as it includes rocks of pre-Cambrian, Paleozoic, Mesozoic, and Cenozoic age, and many of the formations are separated from one another by unconformities. In order to obtain adequate information as to the ground-water conditions and artesian possibilities of the area it was necessary to study the stratigraphic succession in considerable detail, and in this study the earlier investigations of J. S. Newberry, E. D. Cope, N. H. Darton, F. C. Schrader, and J. H. Gardner were very helpful.

Information regarding the water-bearing character of the several formations in the area is included in the descriptions of the townships and land grants (pp. 90-115), but as this information is somewhat scattered, the following brief descriptions of the ground-water conditions of each formation have been prepared from the available data on the lithologic character of the several formations as examined on the outcrop and from well records, to serve as a guide to those who wish to drill wells in the area. It must be understood that there is considerable variation in the water-bearing capacity of different formations.

\section{PRE-CAMBRIAN ROCKS}

The pre-Cambrian rocks form the crest of the Sierra Nacimiento and San Pedro Mountain and crop out in a continuous belt from the northern part of the Jemez Reservation to the north end of San Pedro Mountain. They consist largely of coarse-grained granite ranging in color from cherry-red to brown. Associated with the granite in some places is a black basic intrusive rock, mostly in dikes; this rock is generally coarse grained, but some fine-grained varieties were also observed. The granite and this basic rock are associated in such a manner that their relative ages could not be determined. 


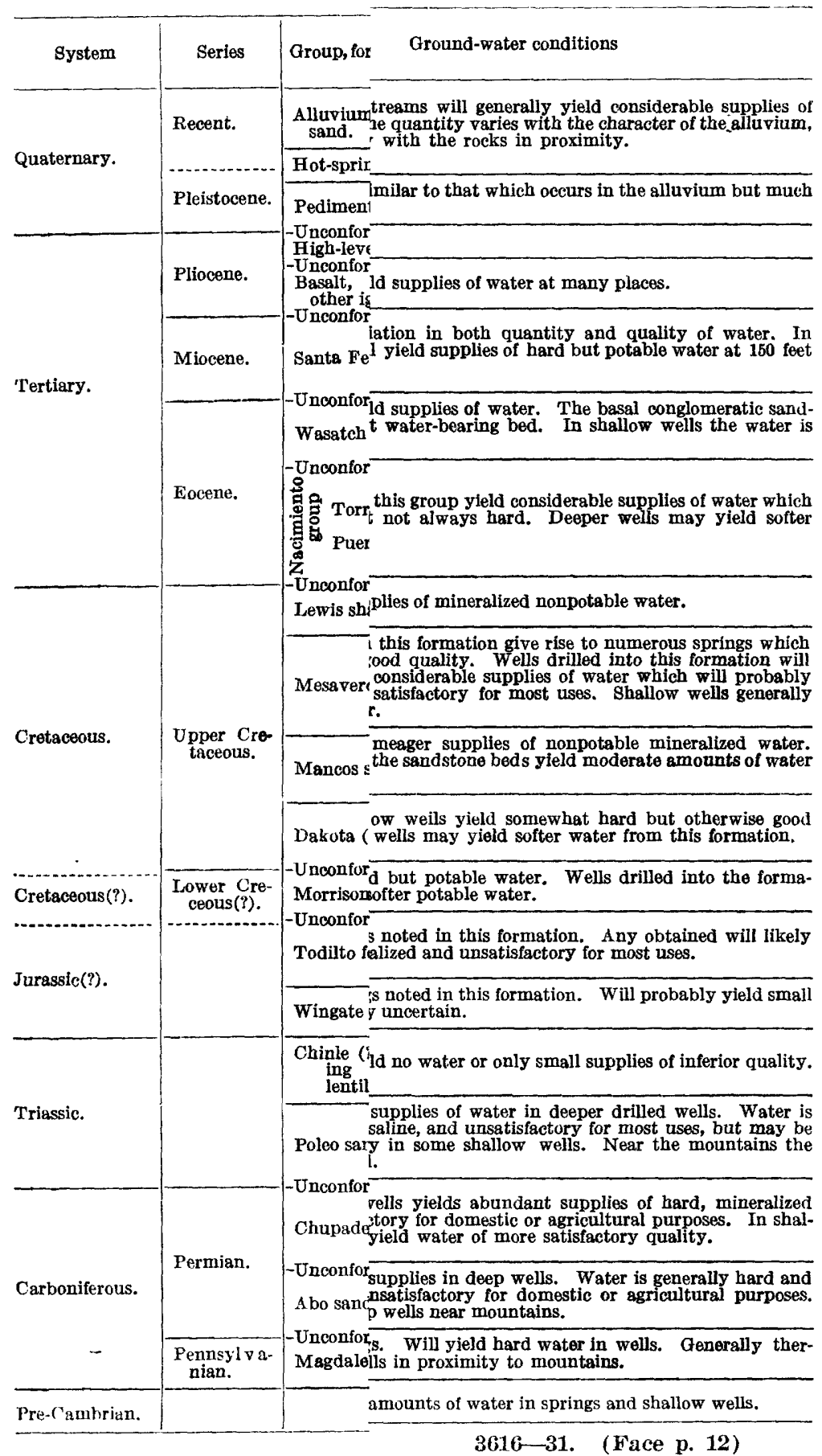


The basal 5 to 10 feet of the Magdalena consists of conglomerate and in many exposures similar coarse-textured beds occur consider. ably higher in the Magdalena section. The basal conglomerate is made up of well-rounded pebbles of quartz, quartzite, and decomposed granite. The proportion of these constituents varies, and some of the beds are very siliceous. Where the siliceous beds have been metamorphosed they have been converted into quartzite. Some of the beds are a typical arkose. The pebbles in the conglomerate do not generally exceed 1 inch in diameter, and the prevailing size is about that of a pea.

The Magdalena group is well exposed on the east side of the Sierra Nacimiento, where it is thick and not cut out by faulting. East of the summit of the Sierra Nacimiento in the latitude between Jemez Pueblo and Canones the Magdalena beds dip eastward at a low angle, and the outcrop to the east is terminated by the Sierrita fault.

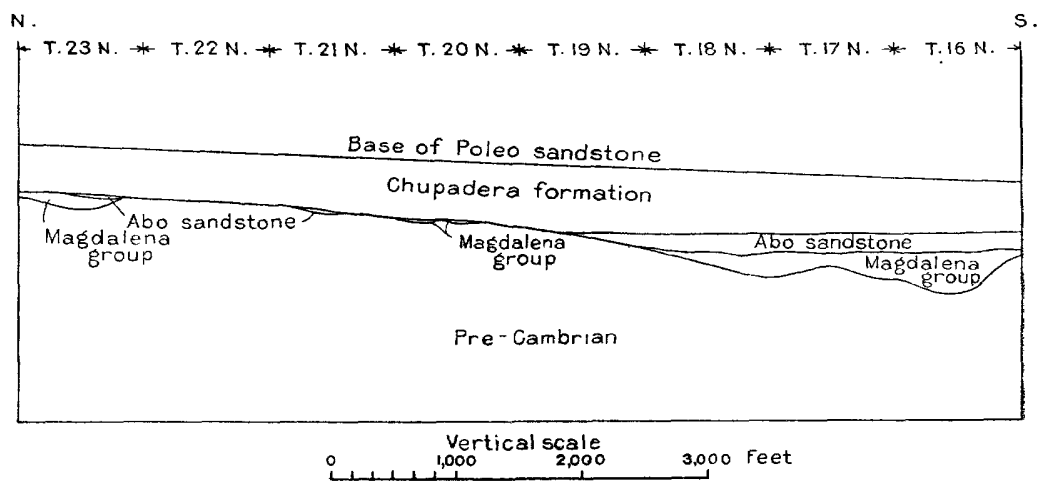

Figure 2.-Diagrammatic cross section showing the general relations of the Carboniferous formations along the west side of San Pedro Mountain and the Sierra Nacimiento

In the Canyon San Diego, north of Jemez Springs, this group crops out in steep cliffs. The Magdalena rocks are exposed also at the northwest side of San Pedro Mountain, but from the northern part of T. 22 N., R. 1 W., to the southern part of T. 19 N., R 1 W., they are absent along the west flank of the range, owing to the post-Magdalena unconformity. The general relations of the Carboniferous formations along the west side of San Pedro Mountain and the Sierra Nacimiento are shown diagrammatically in Figure 2. They are, however, present at some places on the east side of the range and along the crest. From San Miguel Mine Canyon southward along the west front of the mountains the continuity of the Magdalena outcrop is interrupted by faulting. The best exposure of the Magdalena group in this general region is in Canyon San Diego above Jemez Springs, where section 1 was measured. 
1. Section of Magdalena group on west side of Jemez Creek in Canyon San Diego, 2.7 miles north of Jemez Springs

Abo sandstone; approximate contact.

Shale, mostly; largely concealed by talus from overlying rhyolite

Feet

Limestone, massive, argillaceous, with interbedded limy shale; lot 6115f

Shale, maroon to gray, with thin beds of fossiliferous limestone; lot 6115e

Limestone, sandy

Limestone, mottled gray, thin bedded and cherty; 2 feet of arkosic sandstone near base; lot $6115 \mathrm{~d}$

Shale, mostly limy, with thin beds of limestone

Limestone, gray, massive; 2 feet of crinoidal limestone in lower part

Shale, gray and limy $\left\{\begin{array}{l}\text { lot } 6115 c \\ 50 \\ 5\end{array}\right.$

Limestone, thin bedded with partings of shale at base, grading upward into massive limestone

Shale, green to brownish gray, massive

Limestone, greenish, thin bedded, shaly; lot 6115a

Limestone, thin bedded, with interbedded green and gray limy shale; upper part largely concealed; lot 6115

Sandstone, arkosic.

Shale, gray and maroon-purple, with thin limestone beds; largely concealed

Sandstone, red, arkosic

Sandstone, massive, grading up into limestone

Limestone, massive, cherty

Shale, gray and maroon, limy

Limestone, massive, cherty

Limestone, thin bedded, arkosic

Limestone, with interbedded gray limy shale

Limestone, gray, massive; partly concealed

Shale, maroon and gray; largely concealed to Jemez Creek.

In most of the exposures along.the west slope of the mountains the Magdalena group is considerably deformed and hence not well adapted for measuring sections. In Canyon San Diego it is at least 700 feet thick, but part of the top has probably been removed by erosion. On the northwest side of San Pedro Mountain it is in many places not over 25 feet thick. In the eastern part of Tps. 22, 21, and 20 N., R. 1 W., and the northeastern part of T. 19 N., R. 1 W., it was removed by erosion prior to the deposition of the overlying Abo sandstone (see fig. 2) ; however, east of the summit in the same latitude it is well represented. From the southern part of T. 19 N., R. 1 E., southward along the west slope of the range to the northern 
part of T. 16 N., R. 1 E., the Magdalena is from 100 to 400 feet thick where it has not been cut out by faulting. Along the Arroyo Penasco, in the SE. $1 / 4$ sec. 20, T. 16 N., R. 1 E., it is only 10 feet thick.

In the Magdalena outcrop along the west front of the mountain about 3 miles south of Pajarito Peak the beds are considerably deformed, so that it was useless to measure a section, but the following types of rock are included in the succession of about 250 feet-massive fossiliferous limestone; maroon shale; red-brown sandstone; arkose containing fragments of decomposed granite, feldspar, and quartz in a siliceous groundmass; massive limestone containing fragments of granite, feldspar, and quartz from the pre-Cambrian; beds that are to typically arkosic that they resemble decomposed fractured. granite; arkose beds similar to the preceding but including limestone pebbles as much as 3 inches in diameter that contain Magdalena fossils; limestone beds containing red chert fragments; and massive quartzite grit of coarse texture. These varieties of rock are interbedded, and the distinctly arkosic beds are by no means confined to the lower part of the section, in proximity to the underlying preCambrian. Beds of pure limestone are in the minority, and not. more than half of this section, probably considerably less, consists of limestone of even an impure variety.

The following fossils were collected in Canyon San Diego on the west side of Jemez Creek, 2.7 miles north of Jemez Springs (see section 1), and were identified by G. H. Girty, who states that they constitute a representative Magdalena fauna:

Lot 6115f :

Crinoid stems.

Echinocrinus sp.

Fenestella sp.

Pinnatopora sp.

Polypora sp.

Rhombopora sp.

Streblotrypa prisca.

Derbya robusta?

Lot 6115e:

Spirifer triplicatus?

Lot $6115 d$ :

Fusulina secalica.

Productus cora.

Lot 6115c:

Crinoid stems and plates.

Polypora sp.

Productus semireticulatus.

Productus cora.

Productus semireticulatus.

Productus cora.

Productus pertenuis.

Pustula semipunctata.

Spirifer triplicatus var.

Spiriferina kentuckyensis.

Composita subtilita.

Parallelodon sp.

Composita subtilita?

Ambocoelia planiconvexa.

Pteria sp.

Pustula semipunctata.

Pustula nebraskensis.

Spirifer triplicatus.

Composita subtilita. 
Lot 6115a :

Polypora sp.

Rhombopora sp.

Productus cora.

Marginifera splendens?

Composita subtilita.

Lot 6115:

Fusulina secalica.

Polypora sp.

Lingulidiscina sp.

Productus cora.

Productus semireticulatus.

Productus pertenuis.

Pustula nebraskensis.
Cliothyridina orbicularis.

Aviculipecten sp.

Acanthopecten carboniferus.

Griffithides sp.

Marginifera sp.
Pugnoides osagensis?
Dielasma sp.
Composita subtilita.
Allerisma? sp.
Pinna peracuta.

There are a number of springs in the areas where the Magdalena crops out, the water of which comes from the limestone beds. Among these are the spring of A. C. Fish (see p. 91) near the west line of sec. 36, T. 23 N., R. 1 W., and numerous other springs along the west face of San Pedro Mountain in the same general vicinity; also the spring that issues along the fault 3 miles west-southwest of Jemez. There are also springs, mostly thermal, which issue in areas of younger rocks but which obtain a large part of their water from the Magdalena limestones. Among the springs of this type are the San Ysidro, Phillips, and Indian Springs. (See pp. 86-87.) At present there are no drilled wells that obtain their water from the Magdalena limestones, yet it seems safe to predict that these limestones will yield water.

In general it will not be necessary to drill to the rocks of the Magdalena group in order to obtain a water supply, because in the lower settled country, where water supplies are needed, other waterbearing beds lie nearer the surface. Any water obtained from the Magdalena will be hard but probably satisfactory for irrigation, stock, and domestic use except, perhaps, where the Magdalena is deeply covered by younger formations. No report is available as to the water obtained from the Magdalena limestones in the Kaseman well No. 2, which is described on pages 82-83.

\section{PERMIAN SERIES}

\section{GEMERAL RELATIONS}

Overlying the Magdalena group are red beds that belong to the Manzano group of Herrick, ${ }^{9}$ which was divided by Lee and Girty ${ }^{10}$ into three formations, named, in descending order, San Andres lime-

Herrick, C. L., Geology of the white sands of New Mexico: Jour. Geology, vol. 8, p. $120,1900$.

${ }^{10}$ Lee, W. T., and Girty, G. H., The Manzano group of the Rio Grande Valley, N. Mex.: U. S. Geol. Survey Bull. 389, 1909. 
stone, Yeso formation, and Abo sandstone. In western Sandoval County the Abo sandstone and strata of Yeso age have been discriminated, but the San Andres limestone was not positively identified, although it may be represented. According to Darton, the Yeso and San Andres strata in some parts of New Mexico are so much alike in character that they can not be separated from each other with certainty, so that he has used the name Chupadera formation to include both, treating the Yeso and San Andres as members where they can be differentiated. ${ }^{11}$ In this area the Chupadera strata present appear to be chiefly, if not wholly, of Yeso age, but there is a possibility that the upper member of the Chupadera may represent the San Andres limestone. (See section 3, p. 21.) The log of the Kaseman No. 2 well, in the Ojo del Espiritu Santo grant, shows a complete subsurface Permian section. (See p. 83.)

\section{ABO SANDSTONE}

The Abo sandstone, which consists of dark-red to purple coarsegrained sandstone and maroon shale, occurs extensively in this area and is well displayed. It is exposed in the faulted belt west of San Ysidro and Jemez Pueblo, and its entire thickness is seen along Jemez Creek beginning about $11 / 2$ miles south of Canones. The basal beds in contact with the Magdalena group appear at Jemez Springs. The Abo sandstone is also present in the vicinity of Sierrita Mesa and crops out along the flank of the Sierra Nacimiento in the vicinity of La Ventana Mesa and for several miles to the south, also in Senorito Arroyo and westward along the highway at least as far as Rito Penas Negras.

The formation consists of sandstone, grit, and shale. As viewed from a distance it has a maroon or madder-brown color, but closer inspection of individual beds shows maroon shale with pansy-purple bands, maroon-purple shale and sandstone, and some buff and gray sandstone. The sandstone is all coarse and conglomeratic. The following section, measured southwest of Jemez, shows that over half of the formation consists of shale; and though sandstone and grit predominate in some exposures, shale interbedded with the sandstone is present in all. Quartz is the predominant constituent of the coarser beds, but decomposed granite and feldspar are present in hand specimens. No fossils were found in the Abo sandstone.

11 Darton, N. H., Geologic structure of parts of New Mexico: U. S. Geol. Survey Bull. 726, p. 181, 1922; "Red Beds" and associated formations in New Mexico, with an outline of the geology of the State: U. S. Geol. Survey Bull. 794, pp. 21-22, 1929. 
2. Section of Abo sandstone in north face of bluff 3 miles vest-southwest of Jemez

Chupadera formation: Basal conglomerate. Interbedded red-brown to light-purplish sandstone and conglomerate that consists of large red shale balls with associated pebbles of quartz and quartzite. (See section 3.)

Abo sandstone :

Sandstone, maroon, thin bedded, loosely cemented.-..--

Sandstone, coarse, gritty

Shale, maroon, sandy, interbedded with shaly sandstone

Sandstone, madder-brown

Shale, maroon-purple with purple bands

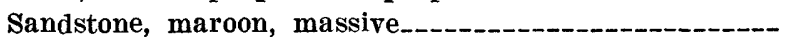

Conglomerate, madder-brown with green streaks; pebbles mostly shale

Shale, grading downward into sandy shale, then into shaly sandstone; maroon to madder-brown

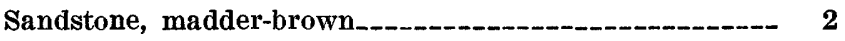

Shale, maroon _- 33

Shale, with sandy bands, maroon at top, grading downward into pansy-purple.

Sandstone, madder-brown to pansy-purple_............ 6

Shale, with some sandstone bands, aster-purple to maroon-purple with green streaks and tints

Magdalena group: Limestone, white, massive.

In most places at the northeast end of San Pedro Mountain, especially in secs. 25 and 36, T. 23 N., R. 1 W., the Abo sandstone rests on the basal arkosic conglomerate beds of the Magdalena, which have withstood post-Pennsylvanian erosion. The Abo sandstone in this region includes a heavy conglomerate consisting of reworked material from the Magdalena as well as angular and subangular fragments of feldspar and granite. In secs. 12 and 13, T. 21 N., R. 1 W., the Abo rests unconformably directly on the pre-Cambrian granite.

On the crest of San Pedro Mountain, between Rito Penas Negras and Senorito Canyon, the relation of the Abo sandstone to the Magdalena group was observed at several places. Although in this locality there is generally 75 to 125 feet of Magdalena strata, the basal conglomerate of the Abo contains much granitic material, indicating that in some places the Magdalena must have been entirely removed. The unconformity between the Abo sandstone and the Magdalena group has been noted by Lee and others at many places in New Mexico. In the Zuni Mountains, according to Darton, ${ }^{12}$ the Abo rests directly on the pre-Cambrian.

${ }^{12}$ Darton, N. H., Geologic structure of parts of New Mexico: U. S. Geol. Surve'y Bull. 726, p. 254, 1922. 
The Kaseman well No. 2 (see pp. 82-83) is probably the only well in this area that obtains water from the Abo sandstone. Probably a large part of the water of samples 2 and 3 from the well is from the Abo sandstone. These samples contained, respectively, 7,780 and 5,580 parts per million of dissolved solids, as sodium chloride, calcium carbonate, and sulphates of calcium, magnesium, and sodium. This water is not potable and is unsatisfactory for irrigation and domestic use. The water in the Abo sandstone in other parts of this area is probably similar in quality to that obtained from the Kaseman well. This sandstone, therefore, should not be regarded as a good water-bearing formation. So far as is known there are no shallow wells in the area that obtain water from this sandstone.

The temperature of the water from the Abo sandstone in the Kaseman well increased with depth and ranged from about $124^{\circ}$ to $142^{\circ}$ F. It is probable that water obtained from wells several hundred feet or more in depth in Abo sandstone near the mountains will be hot.

\section{CHUPADERA FORMATION}

The Chupadera strata present in the area covered by this report consist mainly of red shales which in places have a thickness of 543 to 785 feet. These beds are well exposed along the faulted belt west of San Ysidro and Jemez Pueblo, in the west bluff of the Sierrita Mesa, and along the faulted belt on the east of La Sierrita. Farther north, along the mountains, they dip at a high angle and are well exposed near the head of Arroyo Lopez and Rito Semilla, east of La Ventana Mesa, in San Miguel Canyon, in Senorito Canyon, and west of Cuba between Nacimiento Creek and the head of the Rio Puerco. They also appear near the headwaters of La Jara Creek and Arroyo Salado.

The Chupadera formation in this area consists of two members. The lower one, from a distance and in the sunlight, appears scarlet or geranium-red, contrasting with the underlying maroon Abo sandstone. The rocks of this lower member are mostly soft red argillaceous sandstone, with a few thin bands of shale and limestone. The basal beds are invariably conglomeratic and are cross-bedded in all exposures. Near the south end of the mountains several individual beds are particularly persistent, notably the limestone bed at the top of this lower member, which forms a well-marked white band that is generally easily followed, and also a massive sandstone, about 150 feet thick, near the middle of this member.

The upper member of the Chupadera formation differs somewhat in different parts of the region. In the Jemez Indian Reservation, in the southern part of this area, it consists chiefly of fine to coarse 
massive sandstone, but to the north, near Cuba, it has a coarser texture and many of the beds consist of grit and conglomerate. This upper member does not possess the brilliant red color of the lower member but is generally light buff to gray with a few maroon beds. The sandstones are massive, arenaceous, resistant to erosion, and cliff forming. The upper member is displayed in the Jemez Indian Reservation and in the vicinity of Canones, where it caps the bluff on the east side of the valley of Jemez Creek. An analysis of this sandstone is given on page 25 .

The following section shows that the lower member west of Jemez Pueblo is 534 feet thick and that the upper member in Sierrita Mesa is 249 feet thick, giving the Chupadera formation a total thickness of 783 feet along the south end of the Sierra Nacimiento.

\section{Section of Chupadera formation}

Poleo sandstone.

Chupadera formation:

Upper member (in west face of Sierrita Mesa, in Ojo del Espiritu Santo grant) - Feet

Sandstone, white to buff, soft, thin bedded______- $\quad 47$

Sandstone, buff, massive__._._-_._._- 12

Sandstone, burnt sienna, massive_._._._._._-_._-_ 22

Limestone, brownish___._._._. 10

Sandstone, madder-brown grading upward into burnt sienna, massive________- 121

Shale, red_____. 8

Limestone, gray

Sandstone, Indian-yellow to chrome_-___._._._. 5

Sandstone, yellow, grading downward into red

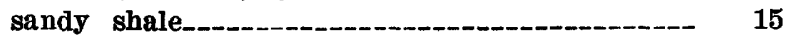

Total thickness of upper member-_._- 249

Lower member (in north face of bluff 3 miles westsouthwest of Jemez Pueblo)-

Limestone, buff to gray. Persistent marker throughout region

Sandstone, ocher-yellow tinted salmon-color, shaly_

Sandstone, coral-red, fine-grained, with red sandy shale partings and mottled gray sandstone bands

Sandstone, coral-red, massive, shaly, fine grained, with a few thin shale partings

Sandstone, alternating beds of gray and coral-red, medium grained.

Sandstone, coral-red with tints of purple, massive, medium to coarse grained, cross-bedded.

Sandstone, coral-red, fine grained._._.....-..--

Sandstone, bright coral-red, coarse grained, crossbedded, partly conglomeratic (consisting of shale and sandstone pebbles); some shale partings_..-- 


\section{Chupadera formation-Continued.}

Lower member-Continued.

Feet

Sandstone, bright red, massive, fractured. Secondary calcite distributed throughout___._._._-_.- 12

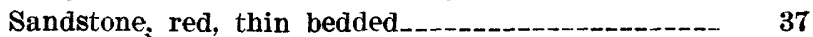

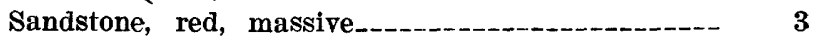

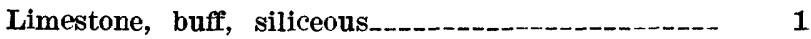

Shale, carmine

Conglomerate and sandstone, madder-brown to light purplish; conglomerate contains mostly large red shale balls with pebbles of quartz and quartzite_

Total thickness of lower member._. 534

Total thickness of Chupadera formation

783

Abo sandstone. (See sec. 2.)

Another section of the Chupadera formation (sec. 4) measured in sec. 25 , T. $21 \mathrm{~N}$., R. $1 \mathrm{~W}$., shows a total thickness of 543 feet. In this section the upper and lower members are not easily separable. Perhaps beds 1 to 8 constitute the upper member and 9 to 11 the lower member. The basal bed here rests on the pre-Cambrian. In the southern part of the mountains in western Sandoval County the individual beds are very persistent.

4. Section of Chupadera formation in sec. $25, T .21$ N., R. 1 W.

Poleo sandstone. (See sec. 6.)

Chupadera formation:

Feet

1. Shale, purple, with streaks of green

2. Sandstone, red, massive, coarse grained, angular cross-bedded; grit in lower 10 feet

3. Grit, white to gray, coarse, mostly siliceous, with some limestone pebbles_-_._-_._- 4

4. Limestone, reddish, impure, shaly.

5. Shale, dark crimson

6. Sand and grit, white and purple, coarse-_.......-

7. Sandstone, conglomerate, and grit; red, red-brown, and gray

8. Limestone and limestone conglomerate

9. Sandstone and shale interbedded; maroon, red, redbrown, and white; cross-bedded; numerous conglomerate and grit layers in the sandstone

10. Sandstone and grit, maroon and scarlet, thin bedded; interbedded with shale of same color.

11. Mostly concealed (probably largely maroon shale) -. Pre-Cambrian granite.

Along the southern part of the Sierra Nacimiento the Chupadera formation rests unconformably on the Abo sandstone, with a basal conglomerate at all places where the contact was studied. This con- 
glomerate consists largely of red shale balls derived from the Abo, with small pebbles of quartz and quartzite. The color is generally similar to that of the Abo. The significance of this unconformity is not made plain by the relations farther north, for nearly everywhere along the northern Sierra Nacimiento and the northwestern part of San Pedro Mountain the Chupadera beds lie directly on the preCambrian. (See fig. 2.) Rich ${ }^{13}$ and Baker ${ }^{14}$ have pointed out that in eastern and east-central New Mexico, also, the Chupadera rests on pre-Cambrian rocks.

The lower member of the Chupadera formation in this region bears a close resemblance to the Yeso strata of the north end of the Sandia Mountains, described by Lee ${ }^{15}$ and recently inspected by the writer. It seems certain that the lower member, at least, of the section in western Sandoval County (sec. 3) has the same stratigraphic position as the Yeso formation of Lee. Also, the brilliant scarlet color that characterizes the strata in both of these areas is distinctive. The upper member of the Chupadera in this area (see sec. 3) is also believed to represent the Yeso, but there is a possibility that it may be equivalent to the San Andres limestone. No fossils were found in the thin limestone beds in this upper member such as occur in the limestone in the Yeso formation in the Sandia Mountains. Apparently the Moenkopi formation is not present in this area.

From surface exposures the upper, light-colored sandstone member of the Chupadera formation appears to be a better water-bearing bed than the lower member. The best data on the ground-water possibilities of the Chupadera formation are obtained from the Kaseman well No. 2, which apparently passed through the formation between depths of 870 and 1,525 feet. (See p. 83.) The chemical character of the water is shown to some extent by analyses of samples from this well. (See p. 83.) The water represented by analysis 1 comes from the Poleo sandstone and the Chupadera formation at a depth of less than 940 feet and contains 11,760 parts per million of dissolved solids; the water represented by analysis 2 comes from the Chupadera formation and the Abo sandstone at $\mathbf{a}^{-}$depth of 940 to 1,810 feet and contains 7,780 parts per million. Both contain sodium chloride, calcium carbonate, and the sulphates of calcium, magnesium, and sodium. Water of this character is not potable and not satisfactory for domestic or agricultural use.

\footnotetext{
${ }^{13}$ Rich, J. L., A probable buried mountain range of early Permian age east of the present Rocky Mountains in New Mexico and Colorado: Am. Assoc. Petroleum Geologists Bull., vol. 5, pp. 605-608, 1921.

14 Baker, C. L., Contributions to the stratigraphy of eastern New Mexico: Am. Jour. Sci., 4th ser., vol. ${ }^{4} 49$, p. $110,1920$.

${ }^{15}$ Lee, W. T., U S. Geol. Survey Bull. 389, p. 19, 1909.
} 
Where the Chupadera formation is near the surface shallow wells will probably yield water of better quality. It is possible that some of the water wells at Jemez may reach this formation, but there the structure is complicated by faulting and the relations are obscured by a cover of alluvium and terrace deposits.

\section{TRIASSIC SYSTEM}

\section{POLEO SANDSTONE}

Throughout the Nacimiento region the red shales of the Chupadera formation are overlain by a sheet of conglomerate or conglomeratic sandstone which is believed to be equivalent to the Shinarump conglomerate but to which Darton has applied the local name Poleo sandstone, first used by Huene. ${ }^{16}$ No fossils were found, and the rearest area in which the Shinarump conglomerate has been identified is the Zuni uplift, ${ }^{17}$ but after observing the Shinarump conglomerate on the south side of the San Juan Basin, the writer believes that the correlation can be made with considerable confidence on the basis of lithologic similarity and position. However, as Darton ${ }^{18}$ has correlated these rocks in the Nacimiento and Chama areas with the Poleo sandstone of Huene, in which Williston and Case found bones of Triassic age, the local name Poleo sandstone is used in this report.

The Poleo sandstone caps most of the synclinal area known as La Sierrita, and its entire thickness is well displayed at the eastern and western edges of the syncline, which is terminated on these two sides as well as the north side by faults. It forms the crest of the steep ridge on the northwest side of the Jemez Indian Reservation. From this ridge northward it is exposed at several localities along the Sierra Nacimiento. The formation gives rise to a hogback west of the Ojo del Espiritu Santo ranch, on the flank of the mountains, and it again crops out in the form of a hogback that extends from a point near the head of Arroyo Olguin to San Miguel Arroyo. Between San Miguel Arroyo, in the Sierra Nacimiento, and Naranja Creek, in San Pedro Mountain, the outcrops of the conglomerate are more or less discontinuous, owing to faults.

The Poleo sandstone consists of interbedded conglomerate and massive buff to gray sandstone, which form cliffs. In the lower 25 to 50 feet it is stained dark brown in many places, presumably by manganese and iron. Though most of the conglomerate is in the lower part of the formation, there is at many places a small amount

\footnotetext{
${ }^{16}$ Huene, F. von, Kurze Mitteilung über Perm, Trias und Jura in New Mexico: Neues Jahrb., Beilage-Band 32, pp. 730-739, 1911.

${ }^{17}$ Darton, N. H., Geologic structure of parts of New Mexico: U. S. Geol. Survey Bull. 726, p. 254, 1922; "Red Beds" and associated formations in New Mexico: U. S. Geol. Survey Bull. 794, pp. 143-144, 1929.

${ }^{18}$ Darton, N. H., op. cit. (Bull. 726), pp. 241-244; (Bull. 794), pp. 158-160.
} 
in the upper beds. The coarse material is prevailingly quartzose, consisting of well-rounded pebbles of quartz, quartzite, and chert, the largest of which are 4 inches in diameter; but the conglomerate also. carries fragments of shale and of maroon to madder-brown sandstone, which are less well rounded and were probably derived from the underlying Abo sandstone and Chupadera formation. Tree trunks, limbs, and fragments of wood are locally plentiful. Crossbedding, both angular and tangential, is a characteristic feature. The following analyses of a piece of sandstone from the Poleo and a piece of sandstone from the Chupadera show that they are very similar except that the latter contains more ferric oxide.

\section{Analyses of samples of sandstone}

[J. G. Fairchild, analyst]

\begin{tabular}{|c|c|c|c|c|c|c|}
\hline & \multicolumn{5}{|c|}{ Per cent soluble in dilute $\mathrm{HCl}(1+1)$} & \multirow{2}{*}{$\begin{array}{l}\text { Per cent of } \\
\mathrm{SiO}_{2} \text { soluble } \\
\text { in boiling } \\
5 \text { per cent } \\
\text { solution of. } \\
\mathrm{Na}_{2} \mathrm{CO}_{3}\end{array}$} \\
\hline & $\begin{array}{l}\mathrm{Fe}_{2} \mathrm{O}_{3}+ \\
\mathrm{Al}_{2} \mathrm{O}_{3}(?)\end{array}$ & $\mathrm{CaO}$ & MgO & $\underset{\mathbf{K}_{2} \mathrm{O}}{\mathrm{Na}} \mathrm{O}$ & $\mathrm{SO}_{3}$ & \\
\hline Poleo sandstone from NW. $1 / 4$ sec. 36 , T. 16 N., & \multirow{2}{*}{$\begin{array}{r}0.19 \\
.78\end{array}$} & \multirow{2}{*}{$\begin{array}{r}0.13 \\
.17\end{array}$} & \multirow{2}{*}{$\begin{array}{r}0.03 \\
.05\end{array}$} & \multirow{2}{*}{$\begin{array}{r}0.07 \\
.06\end{array}$} & \multirow{2}{*}{$\begin{array}{r}0.12 \\
.01\end{array}$} & \multirow{2}{*}{$\begin{array}{r}0.12 \\
.50\end{array}$} \\
\hline $\begin{array}{l}\text { Sandstone of Chupadera formation, from mesa } \\
\text { east of Lower Canyones, San Diego grant (red) }\end{array}$ & & & & & & \\
\hline
\end{tabular}

The Poleo sandstone is about 257 feet thick in the east face of La Sierrita (see sec. 5), but toward the north it thins to less than 100 feet thick. Along San Pedro Mountain in the center of sec. 25, T. $21 \mathrm{~N}$., R. 1 W. (see sec. 6), it is only 97 feet thick. Throughout this region the Poleo rests on the Chupadera formation, from which it is separated by an erosional unconformity. It was doubtless deposited on a relatively flat surface, probably a peneplain.

\section{Section of Poleo sandstone in ridge 1 mile west of San Ysidro}

Chinle (?) formation.

Poleo sandstone :

Sandstone, nearly white, massive

Sandstone, buff, massive

Sandstone, dark brown to reddish brown, massive with a few pebble beds

Sandstone, reddish brown, with dark conglomerate bands

Sandstone, white, massive, coarse grained, with a few quartzose pebbles

Sandstone, reddish brown, massive, with dark layers of siliceous conglomerate

Conglomerate, black and brown, quartzose

Sandstone, gray, massive, with some conglomerate layers

Conglomerate, brown and black, quartzose, with sand layers 
Poleo sandstone-Continued.

Feet

Sandstone, white, massive, coarse grained, saccharoidal, with some conglomerate layers

Conglomerate, brown and black, siliceous, grading upward into gray conglomerate with interbedded sandstone layers

6. Section of Poleo sandstone in the center of sec. 25, T. 21 N., R. 1 W.

[Mean strike N. $10^{\circ}$ E., dip $46^{\circ}$ E.]

Chinle (?) formation (approximate contact).

Poleo sandstone:

Feet

Coarse grit and fine conglomerate, purple, maroonbrown, and white, cross-bedded

Sandstone, thin bedded, and fine grit; white to cream colored, with tints of pink on weathered surface

Sandstone, massive, medium to coarse grained, crossbedded.

Conglomerate and grit, quartzose; quartz pebbles as much as half an inch in diameter.

Sandstone and coarse grit, interbedded, white to creamcolored

Chupadera formation. (See sec. 4.)

Lithologically the sandstone and conglomerate of the Poleo have the appearance of being good water-bearing beds. The Kaseman well No. 1 (p. 82), which was drilled in search of oil, furnishes the best data regarding the water in this formation. This well encountered a large flow of salty artesian water at about 500 feet and was abandoned at 550 feet. This water contains 11,120 parts per million of dissolved solids (analysis 16, p. 78) and is hard and saline and unsatisfactory for domestic or agricultural use. Its temperature was $115^{\circ} \mathrm{F}$. In chemical character and temperature the water is similar to that collected from the Kaseman well No. 2 above 940 feet, which comes from the Poleo sandstone and the upper member of the Chupadera formation. Probably the heavy mineralization of the water from the Poleo is due, in part at least, to seepage from the Chinle(?) formation which contains considerable disseminated soluble mineral matter.

\section{CHINLE (?) FORMATION}

The beds here designated Chinle (?) formation crop out at the south end of the Sierra Nacimiento on each side of the Rio Salado from a point about 1 mile above its confluence with Jemez Creek westward for almost 4 miles. (See pl. 5, A.) The basal beds. which 


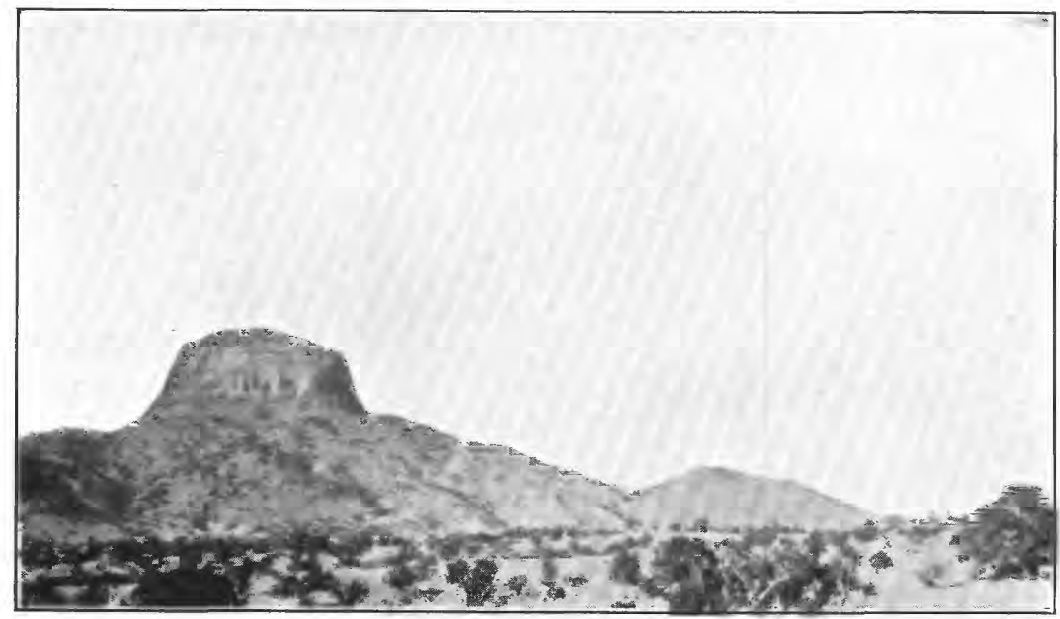

A. CABEZON PEAK, LOOKING SOUTHEAST

The summit and the steep slopes below are hasalt; the lower undulating country is Mancos shale. The basalt is thought to represent an old volcanic plug.

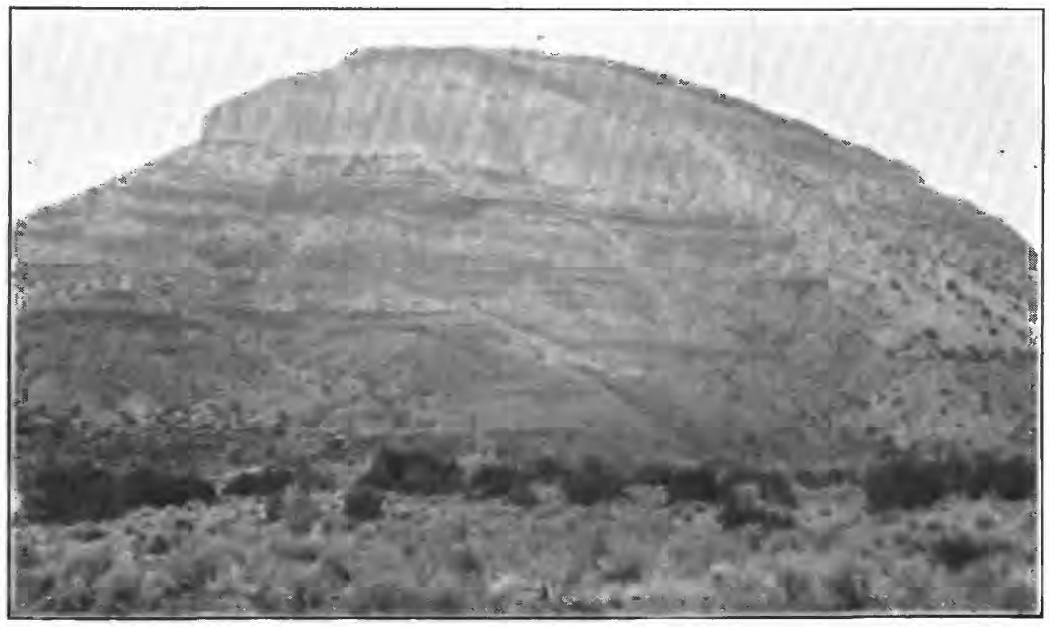

B. RHYOLITE TUFF ON CHUPADERA FORMATION AT THE JUNCTION OF SAN DIEGO AND GUADALUPE CANYONS

The massive rhyolite at the top is light gray; the Chupadera formation below is red. 

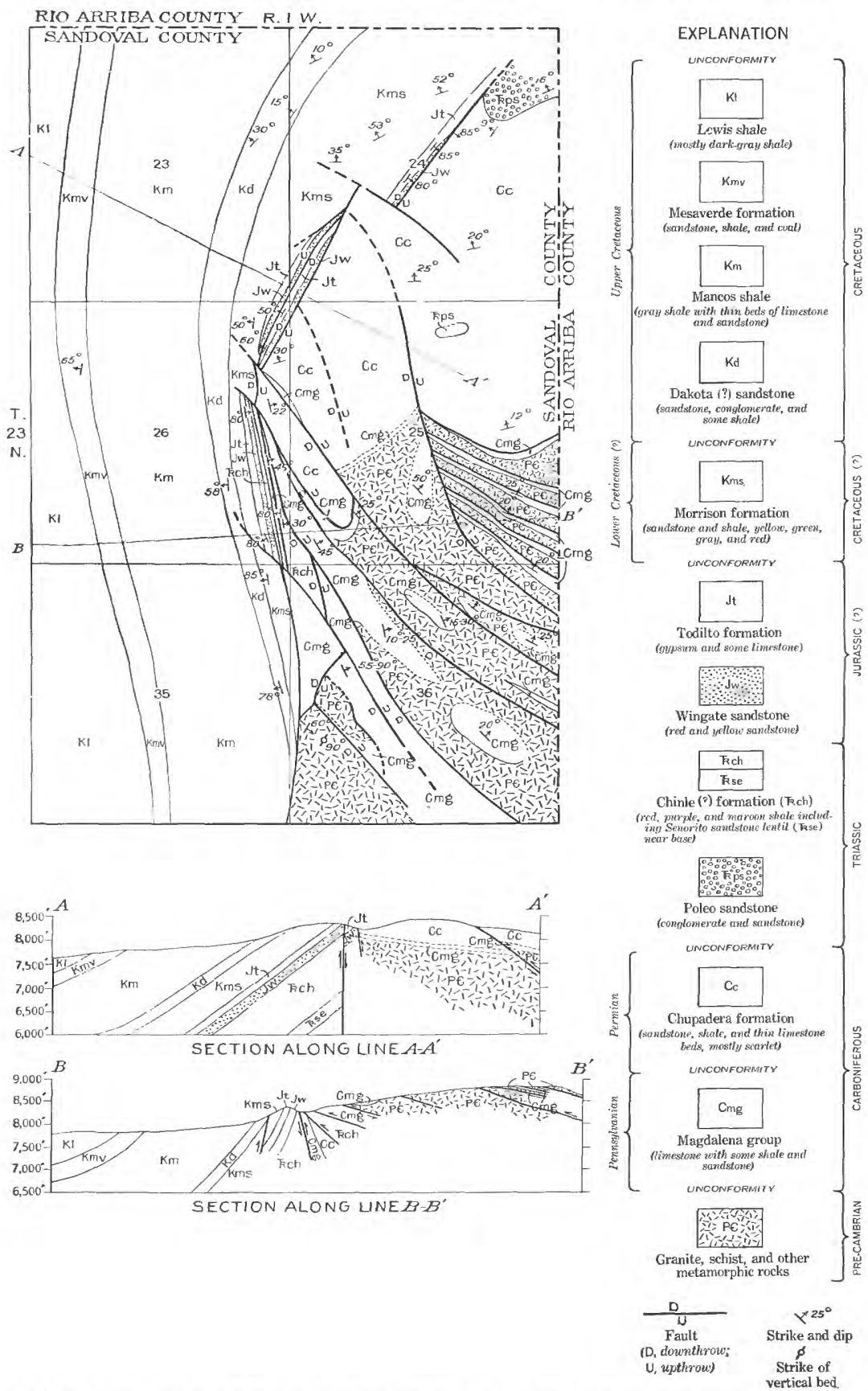

SECTION ALONG LINER-B

vertical bed.

MAP AND SECTIONS SHOWING GEOLOGIC STRUCTURE ALONG THE SIERRA NACIMIENTO OVERTHRUST IN T. 23 N., R. 1 W. 


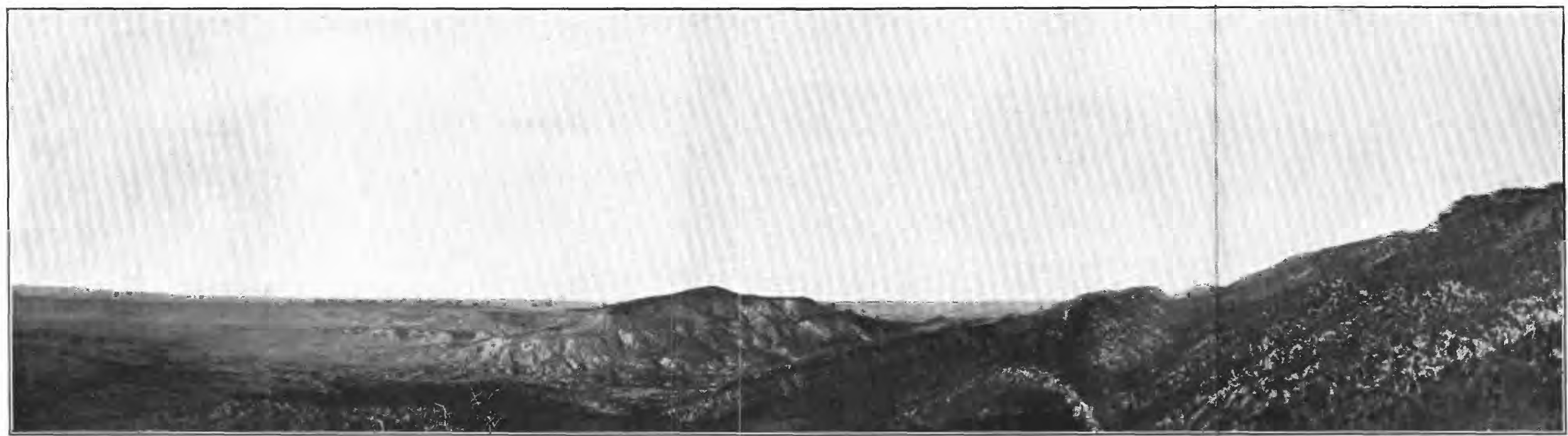

A. PANORAMA FROM POLEO HOGBACK SOUTHEAST OF LA VENTANA MESA, IN SECS. 36, 35, AND 34, T. 19 N., R. 1 W.

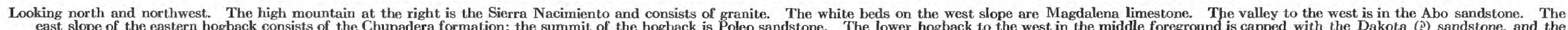

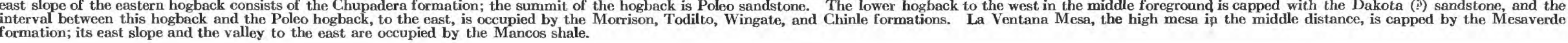

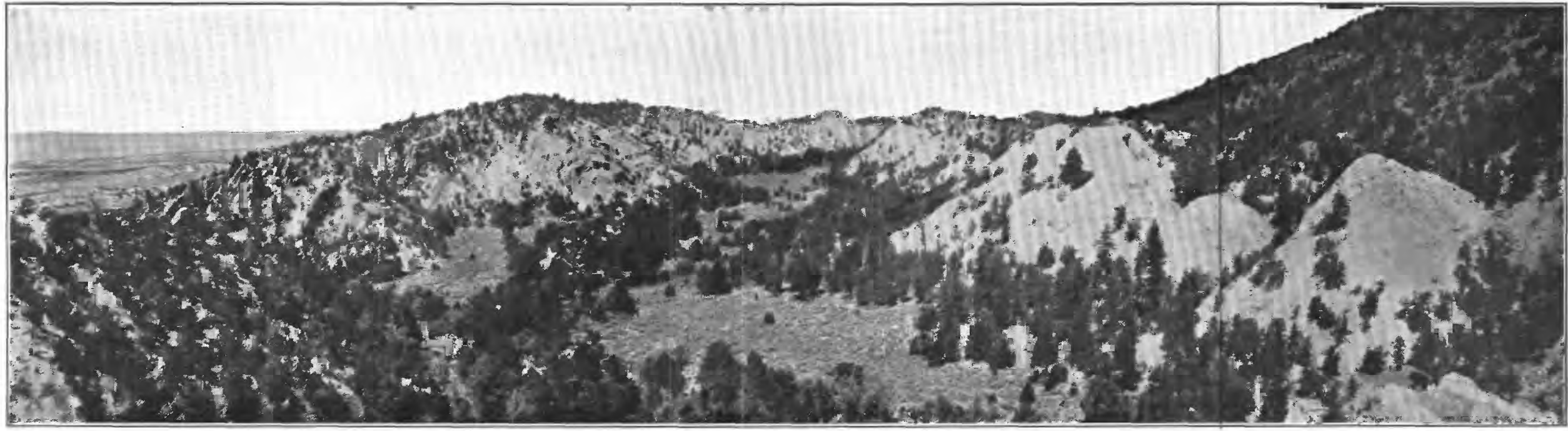

B. PANORAMA SHOWING STRUCTURE IN NE. 14 SEC. 14 AND NW. 14 SEC. 13 , T. 20 N., R. 1 W.

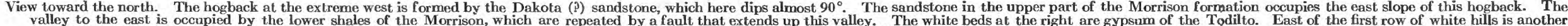

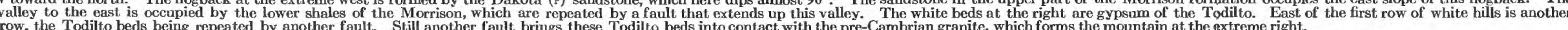





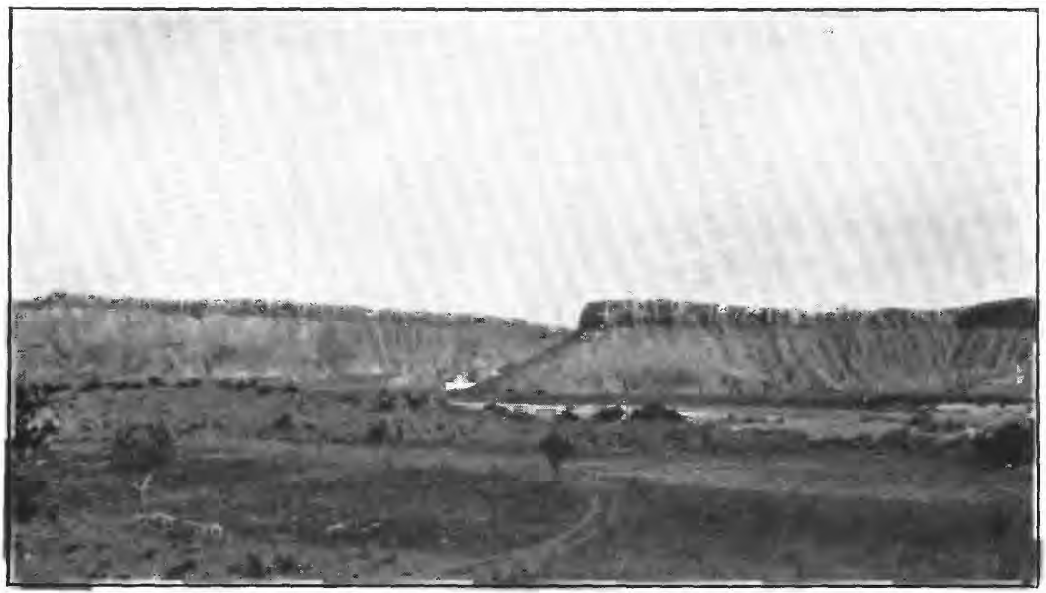

\section{A. MESA BLANCA}

View toward the southeast in secs. 9,10 , and 11, T. 15 N., R, 1 E. The mesa is capped by gypsum of the Todilto formation. The underlying Wingate sandstone is below. The Chinle shale crops out in the lower part of the bluff (darker color) and underlies the valley of the Rio Salado, which is the stream in the middle distance.

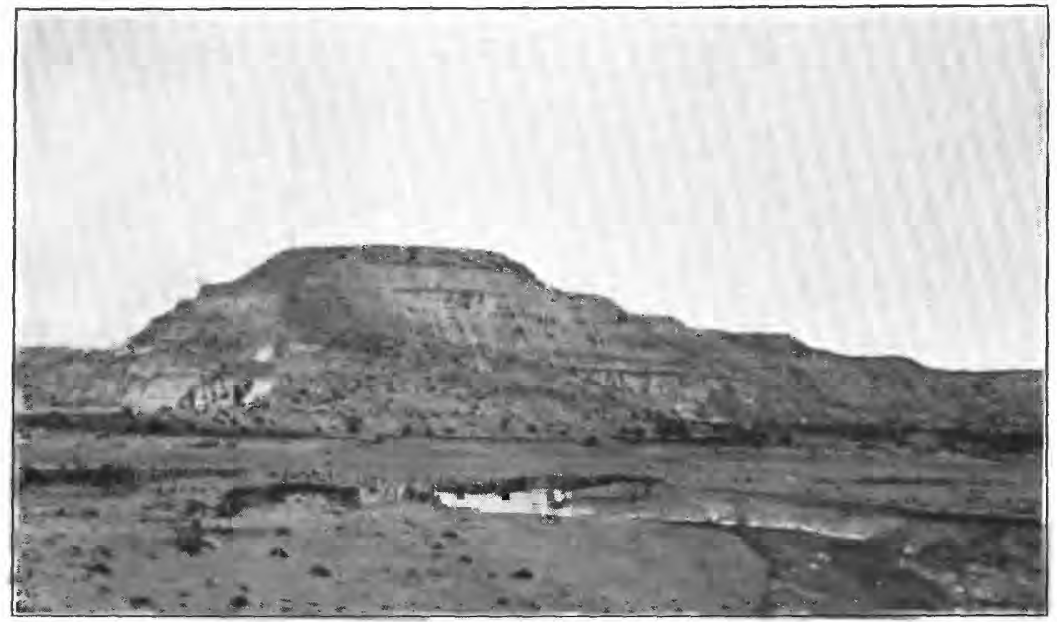

B. MORRISON FORMATION (LOWER PART) IN SEC. 12, T. I5 N., R. I W. View toward the west. 


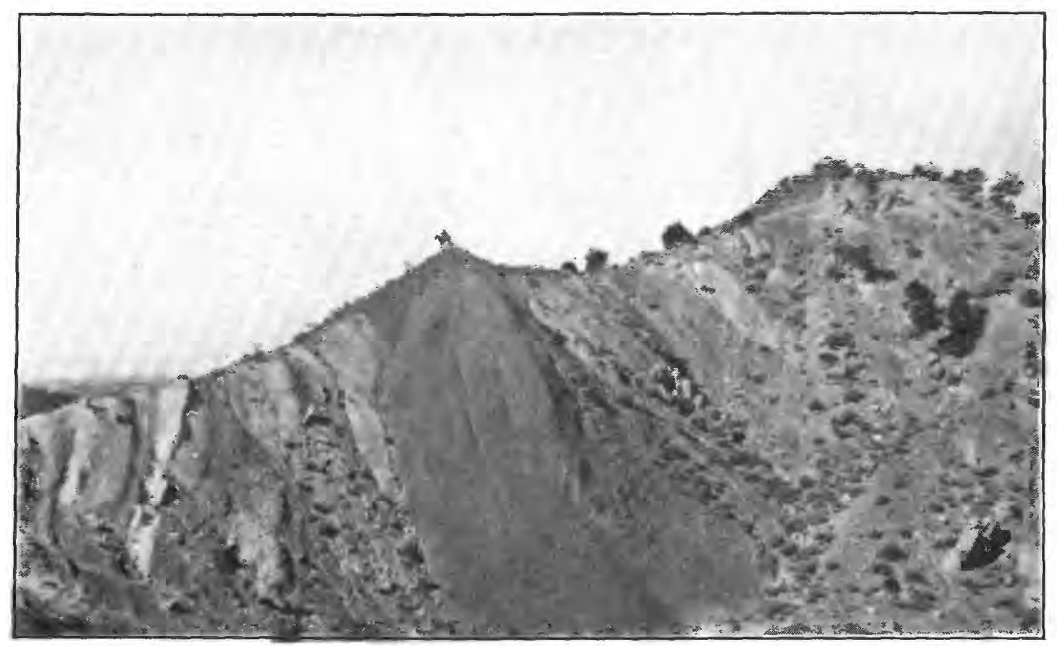

A. MESAVERDE FORMATION IN SW. 1/4 SE. 1/4 SEC. 35, T. 21 N., R. 1 W.

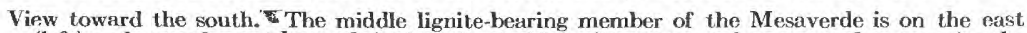
(left) and extends west beyond the horseback rider; the upper sandstone member occupins the hill at the extreme right. The beds here are almost vertical.

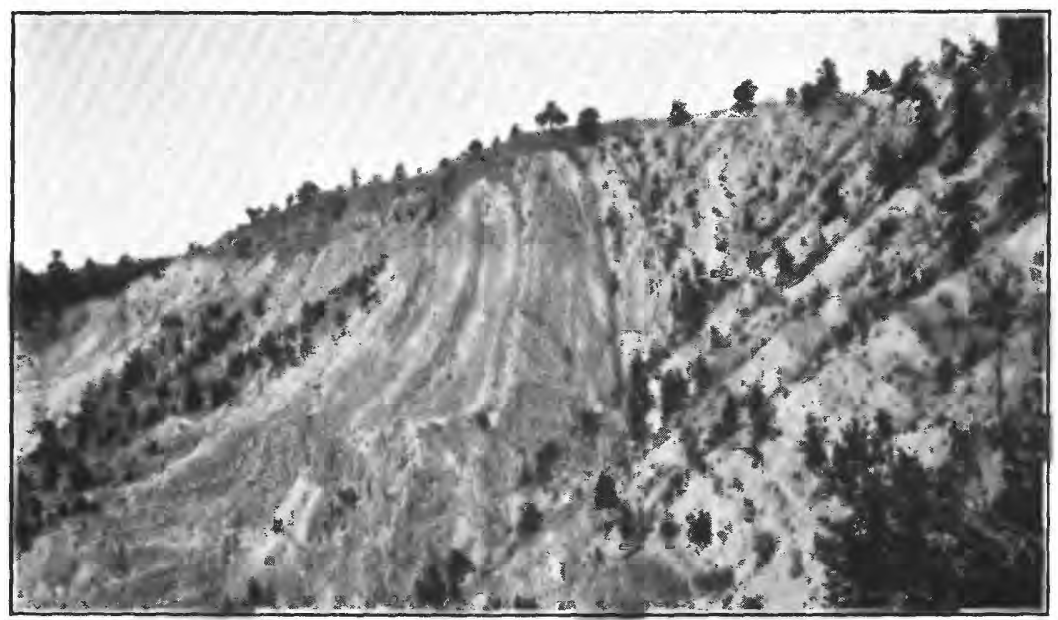

B. NACIMIENTO GROUP (LIGHT-COLORED BEDS AT RIGHT) AND WASATCH FORMATION (DARKER BEDS AT LEFT) IN BLUFF IN SECS. 2 AND 11, T. 21 N., R. $1 \mathrm{~W}$

View toward the north. The beds here are vertical. 


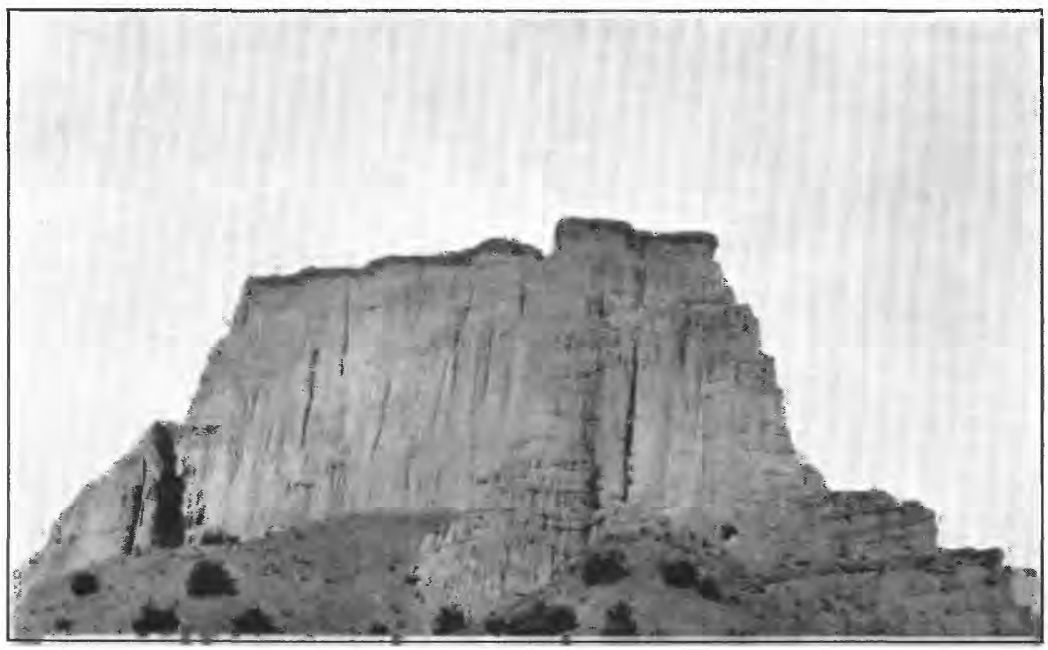

A. SANTA FE FORMATION ABOUT 1 MILE WEST OF JEMEZ PUEBLO

The summit which is capped with later river-terrace conglomerate, represents this remnant of a pediment

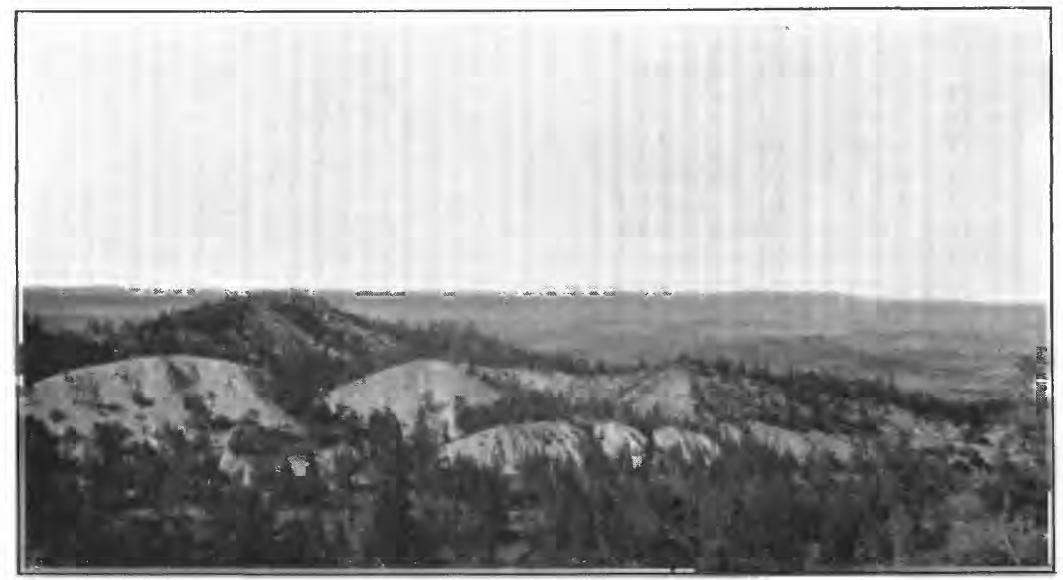

B. TODILTO FORMATION REPEATED BY FAULTING VEAR THE CORNER OF SECS. $23,24,25,26$, T. $23 \mathrm{~N}$, R. I W.

Looking northwest. In each white ridge the summit is capped with the Todilto; the Wingate occupies the slope below. The fault is just back of the first white ridge. (See pl. 2.) The Dakota (?) sandstone caps the farthest hogback to the northwest. 


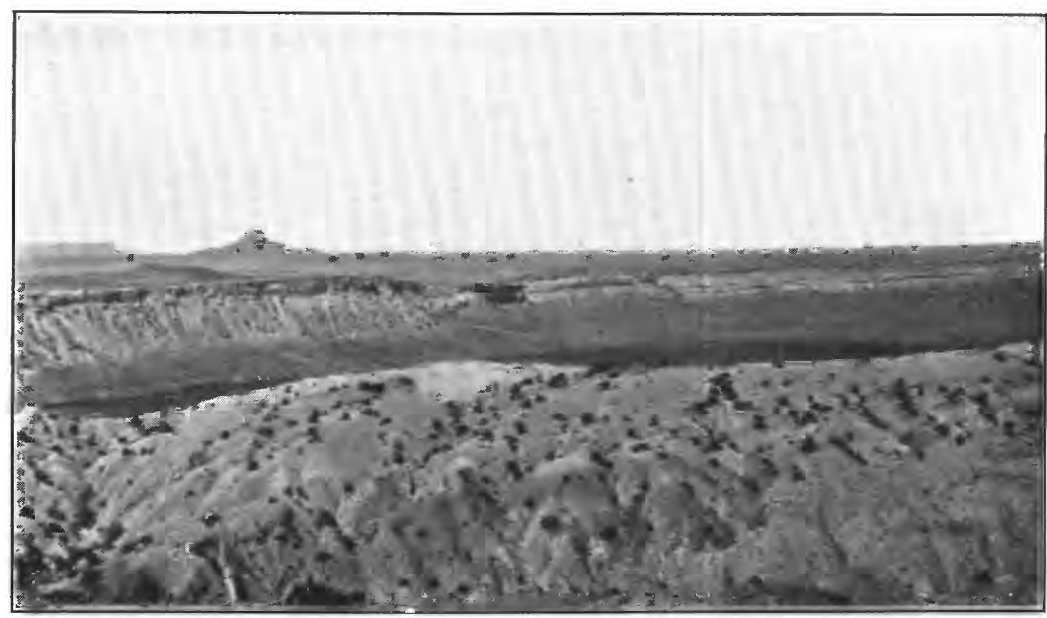

\section{A. SOUTH END OF RIO SAI.ADO ANTICLINE.}

Looking west-northwest from a point about half a mile northeast of the northwest corner of the San Ysidro grant. The white beds in the foteground are gypsum of the Todilto formation along the southeast limb of the anticline. The escarpment in the middle distance is capped by the Todilto, this being the southwest limb of the anticline. The Wingate sandstone occupies the upper two-thirds of the slope below the Todilto, and the Chinle shale occupies the lower part of the slope and the valley in which Arroyo Cachana and Arroyo Penasco flow. Cabezon Peak appears in the far distance.

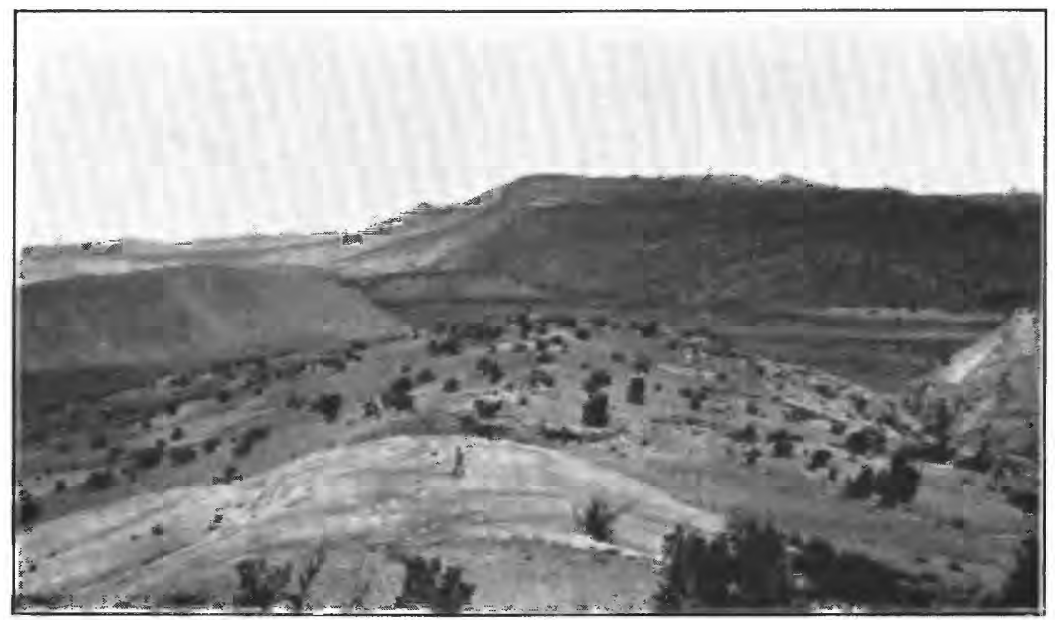

B. SOUTH END OF TIERRA AMARILLA ANTICLINE LOOKING NORTH FROM THE EAST SIDE OF SFC. 17, T. 15 N., R. 1 E.

The white deposits in the center and foreground are thermal-spring deposits. The south group of the San Ysidro Springs issue from a crack that extends northward along the crest of the ridge. Other springs occur along the west slope and in the valley of the Rio Salado, to the north. There are also many extinct-spring craters, like that shown in Plate $1,0, B$. The ridge to the northwest is capped with gypsum of the Todilto, dipping steeply west, with the Wingate and Chinle below, this being the west limb of the anticline. The white beds to the extreme right are Todilto gypsum on the east limb. The mesa to the right in the distance is the Sierrita Mesa, which is capped with the Poleo sandstone. It is terminated on the west (left) by the Sierra Nacimiento fault, which is marked by the steep escarpment, the soft slope on the west being on the downthrown side. 
rest conformably on the Poleo sandstone, are exposed on the north side of the stream, and the topmost beds appear in the lower part of the gypsum-capped bluff known as Mesa Blanca on the south side. The middle portion of the formation is not exposed in this locality. Along the west slope of the Sierra Nacimiento there are many exposures of the beds. From a point about 1 mile north of the south line of the Ojo del Espiritu Santo grant northwestward to the Cuchillo Blanco, where there is a general westerly dip, the average width of the Chinle(?) outcrop is about 2 miles. North of that place the dip steepens and the outcrop is considerably narrower, though more or less continuous to Nacimiento Creek and beyond. At several places some of the beds are concealed by faulting. Farther north the Chinle(?) formation crops out extensively, but here also the continuity of exposure is interrupted by faulting.

The upper half of the Chinle(?) formation consists largely of scarlet to poppy-red argillaceous shale with interbedded arenaceous shale and a few thin beds of conglomerate. Approximately the lower half of the formation is darker, ranging in color from maroon to purple; the color gradation between the upper and lower members is gradual. All the beds are predominantly shale, but in greater part the lower member contains more sandstone. In San Miguel Mine Canyon (see sec. 7) the Chinle(?) formation was found to be about 950 feet thick, which is about the average thickness in this area.

\section{Section of Chinle ( 9 ) formation in San Miguel Mine Canyon, in the W. 36} sec. 13, T. 19 N., R. 1 W.

Wingate sandstone.

Chinle(?) formation:

Feet

Shale, reddish pink with green streaks, grading down into red with lavender tints; a few thin beds of conglomerate; strike N. $17^{\circ}$ W., dip $43^{\circ} \mathrm{W}$

Shale, maroon-purple with green streaks; a few thin beds of sand; strike $\mathrm{N}$., dip $50^{\circ} \mathrm{W}$

Sandstone, maroon-purple, with interbedded greenish shale; strikes N. $5^{\circ} \mathrm{W}$., dip $50^{\circ} \mathrm{W}$

Senorito sandstone lentil(?): Sandstone, grayish green and maroon, thin bedded, crenulated; strike N. $10^{\circ}$ W., dip $50^{\circ} \mathrm{W}$

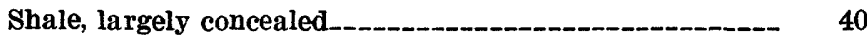

Poleo sandstone.

953

From a point south of the head of Naranja Creek southward to San Miguel Canyon there is a sandstone near the base of the Chinle (8) formation which is a distinct unit and to which the name Senorito sandstone lentil is here applied, because it is well exposed in Senorito Canyon.

$3616-31-3$ 
8. Section of Senorito sandstone lentil in Senorito Canyon

Chinle (?) formation:

Senorito sandstone lentil:

Sandstone, massive, with several streaks of conglomerate; tan with greenish tint; cross-bedded, horizontally truncated; contains fragments of stems

Conglomerate and sandstone

Sandstone, massive, cross-bedded, horizontally truncated; tan to yellow, white with greenish tints; contains fragments of twigs, etc.

The Senorito sandstone lentil differs in certain lithologic features from the Poleo sandstone, which in the San Pedro Mountain region is essentially a coarse sandstone containing much less conglomerate than it does at the south end of the Sierra Nacimiento. The Senorito sandstone was very useful in working out the structure, because it gives rise to a ridge at most places.

Although the section of the Senorito sandstone lentil given above does not show a conglomerate at the base, there is at most places a conglomerate about 10 feet thick, consisting of small limestone pebbles that average about three-eighths of an inch in diameter. Most of this limestone conglomerate contains an abundance of pebbles of red jasper generally about half an inch in diameter. Red jasper pebbles are not characteristic of the Poleo.

The Senorito sandstone lentil is easily traceable south to San Miguel Canyon. Farther south, in San Miguel Mine Canyon, there is 13 feet of conglomerate and sandstone (see sec. 7) separated from the Poleo by only about 40 feet of shale. Distinctive features of this sandstone are its maroon-purple color and thin bedding, with the laminae crenulated and wavy. From San Miguel Mine Canyon southward at many places along the range a thin-bedded maroonpurple crenulated sandstone occurs above the Poleo, in some places lying directly on it. This maroon-purple sandstone is probably the southward continuation of the Senorito sandstone lentil.

At the south end of La Sierrita there is a sandstone with basal conglomerate which caps many of the hills north of the Rio Salado. The sandstone, which is from 3 to 10 feet thick, is red-brown to maroonpurple and thin bedded; the laminae are highly crenulated. The basal conglomerate of this sandstone consists largely of limestone fragments in a sandstone matrix. The interval from this sandstone to the Poleo in this area is from 10 to 50 feet, the interval increasing toward the north. This is in all probability the stratigraphic equivalent of the Senorito sandstone lentil. 
The stratigraphic position and similarity in lithologic character lead the writer to correlate the distinctive shale above the Poleo sandstone and below the Wingate sandstone with the typical Chinle formation (Upper Triassic) of the Navajo country, described by Gregory. ${ }^{19}$ But as the beds do not contain fossils and are not continuous with the typical Chinle formation, and as the equivalency of the underlying Poleo sandstone with the Shinarump conglomerate has not been completely established, the beds are in this report called Chinle (?) formation, as in Darton's recent reports on this region.

The Senorito sandstone lentil of the Chinle (?) formation will doubtless prove to be water bearing, but the water will probably be of poor quality, like that found in the Poleo. The body of shale that forms most of the Chinle (?) strata is impermeable and will not yield much water. Any water obtained from the Chinle (?) formation will probably prove to be highly mineralized.

\section{JURASSIC (?) SYSTEM}

\section{WINGATE SANDSTONE}

The Wingate sandstone is best exposed along the south and east sides of the Sierra Nacimiento. It appears mostly in bluffs, as in Mesa Blanca, where it underlies the white gypsum of the Todilto formation, which caps the mesa. West of Mesa Blanca, in the valley known as Tierra Amarilla, the Wingate is at the surface, and 11/2 miles northwest of San Ysidro the upper beds of the Wingate are exposed in a small area. On the west side of the mountains the Wingate crops out at many places. It is well displayed from a point about 2 miles southwest of Sierrita Mesa northward as far as Cuchillo Blanco. From Cuchillo Blanco to San Pablo Canyon it crops out continuously, but from San Pablo and Senorito Canyons northward the continuity of the outcrop is interrupted by faulting at several places. North of the headwaters of the Rio Puerco the Wingate sandstone has been cut out in places by faulting.

The Wingate sandstone in this area is rather soft and weathers down easily into a smooth slope. (See pl. 7, B.) It is exposed only in bluffs where it is protected from erosion by the overlying Todilto, differing in this respect from the massive cliff-making Wingate in the Zuni Plateau ${ }^{20}$ and Navajo country. Measurements of the Wingate and the overlying Todilto are given in section 9.

\footnotetext{
${ }^{10}$ Gregory, H. E., The geology of the Navajo country : U. S. Geol. Survey Prof. Paper 93 , pp. $42-47,1917$.

${ }_{20}$ Dutton, C. E., Mount Taylor and the Zuñi Plateau: U. S. Geol. Survey Sixth Ann. Rept., pp. 136-137, 1885. Gregory, H. E., op. cit., p. 53. Darton, N. H., A reconnaissance of parts of western New Mexico and northern Arizona: U. S. Geol. Survey Bull. 435, pp. 44-48, 1910; "Red Beds" and associated formations in New Mexico: U, S. Geol. Survey Bull. 794, p. 33, 1929.
} 
The Wingate sandstone comprises two members; the upper one consists of white, bluff, and light-tan sandstone, which in section 9 is about 88 feet thick, and the lower one consists mostly of red and pinkish sandstone about 140 feet thick. Throughout this area both of these members are characteristic of the Wingate and their thickness varies but slightly. The Wingate is prevailingly fine grained and cross-bedded, though the cross-bedding is best displayed in the lower, red member.

9. Section of Todilto formation and Wingate sandstone in the $S W .1 / 1$ sec. 1 , T. 19 N., R. 1 W.

Morrison formation.

Todilto formation:

Limestone

Gypsum. Lower third contains much shaly limestone. The proportion of gypsum increases gradually upward, and the purest gypsum is in the upper half--

Limestone, dark gray, thin bedded; shaly, with seams of gypsum

\section{$1051 / 2$

Wingate sandstone:

Sandstone, thin bedded, shaly________________ $2 \pm$

Sandstone, tan

Sandstone, marine, blue grading down into buff_-.-.- $\quad 31 / 2$

Sandstone, ocher-yellow grading down into white; massive but soft

Sandstone, grading downward through white, flesh color, and pink; transitional in color between the beds above and those below.

Shale, brick-red, pinkish on weathered surface, grading up into member above. No definite contact_-_-- 6

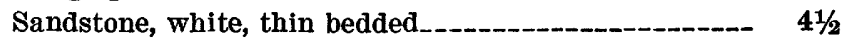

Chinle (?) formation: Typical purple-maroon shale with streaks of green.

Throughout this area the Wingate sandstone rests on the Chinle (?) formation and apparently there is no unconformity of any magnitude between them.

On the basis of lithology and stratigraphic position this sandstone was correlated by Darton ${ }^{21}$ with the Wingate of Dutton ${ }^{22}$ and Gregory. ${ }^{23}$ Though originally regarded by Dutton as Triassic,

${ }^{21}$ Darton, N. H., Geologic structure of parts of New Mexico: U. S. Geol. Survey Bull. 726, pp. 175-184, 1922.

22 Dutton, C. E., op. cit., p. 137.

23 Gregory, H. W., op. cit., p. 55. 
the Wingate was later assigned to the Jurassic by Gregory; it is now regarded as probably belonging to the Jurassic.

In this area the Wingate sandstone is more or less compact and is not so permeable as the Poleo sandstone or the Dakota (?) sandstone. No springs were noted in the Wingate in this area. Owing to the fact that the Todilto formation, which here consists mostly of gypsum, overlies the Wingate sandstone, it is very probable that any water obtained in the Wingate will be highly mineralized and of unsatisfactory quality.

In the Navajo country the Wingate sandstone gives rise to a number of springs that yield water of good quality. ${ }^{24}$ There the Wingate is more permeable and the overlying Todilto is not gypsiferous and hence is less likely to damage the quality of the water in the Wingate.

\section{TODILTO FORMATION}

The Todilto formation consists of a thick bed of gypsum with a thin limestone member at the top and another at the bottom. It caps Mesa Blanca, extends westward around Tierra Amarilla, and appears about 1 mile northwest of San Ysidro. A wide outcrop extends from a point near the junction of Arroyo Bernalillito and the Rio Salado northward for several miles, then swings around to the east, giving rise to the Cuchillo Blanco. Northward from the Cuchillo Blanco the Todilto crops out along the flank of the mountain almost continuously to a point south of Nacimiento Creek. From Nacimiento Creek northward it is cut out by a fault, but it reappears in sec. 24, T. 21 N., R. 1 W., and again in the northeast corner of the area. (See sec. 9, p. 30.)

The Todilto formation ranges in thickness from 60 to 125 feet. The limestone at the base is from 4 to 10 feet thick, whereas that at the top is generally only a few inches thick. The outcrop at most places is marked by a ridge, as the Todilto is more resistant to erosion than the soft Wingate below and the Morrison shale above. Its white color makes it conspicuous and a very useful bed in mapping structure. Plate $7, B$, shows the 'Todilto repeated by faulting.

The lower part of the formation, above the basal limestone, contains considerable shale and shaly limestone as lenses in the gypsum; the upper two-thirds of the gypsum is generally pure. (See sec. 9, p. 30.) Some features of this gypsum deposit have been described

\footnotetext{
${ }^{24}$ Gregory, H. E., The Navajo country-a geographic and hydrographic reconnaissance of parts of Arizona, New Mexico, and Utah: U. S. Geol. Survey Water-Supply Paper 380, p. 138, 1916.
} 
by Reagan, ${ }^{25}$ Herrick, ${ }^{26}$ Shaler, ${ }^{27}$ and Darton. ${ }^{28}$ Darton ${ }^{29}$ has correlated the gypsum and the associated limestone with the Todilto formation of Gregory. In the type locality, in Todilto Park, the formation is only 10 feet thick and consists entirely of limestone.

The Todilto throughout this area rests with apparent conformity on the Wingate sandstone. In the Navajo country, according to Gregory,$^{30}$ it contains pebbles of limestone at the base.

The Todilto formation may yield water, but the water will undoubtedly contain so much gypsum in solution that it will be nonpotable and unsatisfactory for most uses. In drilled wells any water obtained in the Todilto will probably be so highly mineralized that it will have to be cased off.

\section{CRETACEOUS (?) SYSTEM}

\section{LOWER CRETACEOUS ( ?) SERIES}

MORRISON FORMATION

The Morrison formation makes the crest of the hogback at the northwest end of San Pedro Mountain. ..It.is.cut,out by.a fault gbout 3 miles south of the Sandoval-Rio Arriba County line and reappears * again in a narrow outcrop in sec. 24, T. 21 N., R. 1 W. A fault again brings it to the surface in secs. 1 and 2, T. $20-\mathrm{N}$ :, R. $1 \mathrm{~W}$., and from this locality southward the outcrop is continuous to a point where it swings around the south end of the Sierra Nacimiento. It is also exposed in a narrow strip on the east side of the mountains west of San Ysidro.

The section of the Morrison formation measured in the hill known as Los Bancos (see sec. 10) shows a thickness of 710 feet, but apparently the thickness in San Miguel Canyon is about 950 feet. The Morrison formation comprises at least two easily recognizable members. The lower one, 181 feet thick, consists of maroon soft sandy shale, calcareous in places, containing bands of white and gray sand. Its upper limit, however, is not definite, for there is some gradation of materials so that a part of the overlying white sand might correctly be assigned to it. The upper member consists of alternating beds of soft shale and resistant sandstone; its prevailing colors are malachite-green, greenish buff, maroon, lavender, white, and tan, and in some places beds of scarlet chert are prominent.

\footnotetext{
${ }^{25}$ Reagan, A. N., Geology of the Jemez-Albuquerque region, N. Mex.: Am. Geologist, vol. 31, pp. $77-78,1903$.

20 Herrick, H. N., Gypsum deposits in New Mexico: U. S. Geol. Survey Bull. 223, pp. 94-95, 1904.

${ }^{27}$ Shaler, M. K., Gypsum in northwestern New Mexico: U. S. Geol. Survey Bull. 315, pp. 260-265, 1907.

${ }^{28}$ Darton, N. H., in Stone, R. W., and others, Gypsum deposits of the United States : U. S. Geol. Survey Bull. 697, pp. 181-184, 1920.

${ }^{29}$ Darton, N. H., Geologic structure of parts of New Mexico: U. S. Geol. Survey Bull. 726, p. 244, 1922.

${ }^{30}$ Gregory, H. E., op. cit., pp. 55-56.
} 
The Morrison formation gives rise to some marked topographic features. The upper member, with its beds of resistant sandstone, makes up most of the outer hogback that parallels the mountain from Senorito Canyon to a point south of Arroyo Olguin. From the Ojo del Espiritu Santo ranch house to the south end of the range, where the westward dip of the Morrison is less than it is on the north, the outcrop of the Morrison is wider and the alternating hard and soft layers give rise to an extremely rugged dissected semibadland topography. The soft shales of the lower member underlie the depression and valleys. (See pl. 5, B.)

A section of the Dakota (?) sandstone and the upper part of the Morrison formation was measured in Senorito Canyon. (See sec. 13, p. 37.) This section shows that there are about 210 feet of beds belonging to the upper member of the Morrison formation, and the entire thickness of the upper member is not much greater than this east of Cuba. Two miles to the north, in the SW. 1/4 sec. 24, T. 21 N., R. 1 W., the lower maroon member of the Morrison is about 98 feet thick, so that the entire formation east of Cuba is probably not over $\overline{3} 50$ feet thick. In this area, however, the deformation has been intense and the thinning of the formation may be due in part to squeezing.

\section{Section of Morrison formation in Las Bancos}

Dakota (?) sandstone.

Morrison formation:

Upper member :

Feet

Shale, variegated, predominantly malachite-green with pinkish bands; contains several sandstone lenses of peculiar mottled appearance and a thin red chert band 20 feet from the base

Sandstone, buff to greenish yellow, massive____.__ $\quad 17$

Shale, light gray to buff-_-_- 12

Sandstone, buff

Shale, variegated, light gray, greenish, and reddish_

Sandstone, light buff, cross-bedded; includes at base conglomerate band 2 inches thick which contains pebbles less than 1 inch in diameter consisting of quartzose igneous rock. (This sandstone is thinner in some places)

Intraformational unconformity.

Shale, green

Limestone, concretionary band

Shale, greenish with purple-maroon bands

Sandstone, whitish, coarse-grained, cross-bedded, poorly indurated. (Within a short horizontal distance this sandstone attains a thickness of $20 \pm$ feet)

55

Shale, mostly greenish, with lavender band near center; arenaceous 
Morrison formation-Continued.

Upper member-Continued.

Sandstone, greenish yellow to buff-white, massive, cliff forming; contains conglomerate layers with pebbles of green shale and greenish shaly sandstone. (This member is notably lenticular; within a quarter of a mile to the southwest it is $\mathbf{1 0 0}$ feet thick, and within less than a mile to the north it is 25 feet thick)

Shale, maroon with greenish tint, sandy, interbedded with greenish sandstone.

Sandstone, buff-yellow with greenish tint, some maroon layers, soft

Feet

Sand, white with some purple-tinted bands.

Total upper member

Lower member :

Shale, alternating beds of maroon and gray; contains some beds of compact sandstone; maroon to white

Shale, appears purple owing to interbanding of white and maroon; limy and sandy, with several layers of massive sandstone

Total lower member

181

Todilto formation.

Total Morrison formation

At all places where the basal contact of the Morrison formation was observed the lower maroon shale rests on the limestone bed at the top of the Todilto formation. There is no appearance of unconformity, but as the Navajo sandstone, which rests on the Todilto throughout the plateau country to the west, is absent, it is possible that an unconformity exists. It seems more probable that the Navajo sandstone was never deposited in this area.

No fossils were found in the Morrison in this area. The age of the formation is not definitely established, and there is a difference of opinion as to whether it is Jurassic or Cretaceous. The United States Geological Survey for the time being classifies it as Cretaceous (?), though it is regarded by many geologists as Jurassic.

The Morrison formation, as shown by section 10, contains considerable sandstone. The porosity of two samples of the sandstone (Nos. 403 and 405 in the following table) is 16.26 and 13.93 per cent. Though these sandstones are less porous than those in the Mesaverde and Dakota (?), yet they are sufficiently permeable to be regarded as prospective aquifers. It is recommended that where a well drilled into the Dakota (?) fails to yield a water supply, drilling be continued into the Morrison formation. A locality where it may be 
desirable to drill to the Morrison for a water supply is along Arroyo Chachulie in the latitude of Los Bancos, where the Dakota (?) sandstone is close to the surface and may fail to yield much water.

Specific gravity and porosity of rocks in western sandoval County, N. Mex.

[Determinations by Norah Dowell Stearns]

\begin{tabular}{|c|c|c|c|c|}
\hline $\begin{array}{l}\text { Labo- } \\
\text { ratory } \\
\text { No. }\end{array}$ & Location & Formation & $\begin{array}{c}\text { Specific } \\
\text { gravity } \\
\text { of oven- } \\
\text { dried } \\
\text { sample }\end{array}$ & $\begin{array}{l}\text { Poros- } \\
\text { ity } \\
\text { (per } \\
\text { cent) }\end{array}$ \\
\hline 416 & NE. 1/4 NW. 1/4 sec. 20 , T. 19 N., R. & Mesaverde formation & 2.00 & 24.69 \\
\hline $\begin{array}{l}413 \\
418 \\
407\end{array}$ & $\begin{array}{l}\text { SW. } 1 / 4 \text { NW. } 1 / 4 \text { sec. } 20, \text { T. } 19 \text { N., R. } 1 \text { W.- } \\
\text { NE. } 1 / 4 \text { sec. } 35, \text { T. } 20 \text { N., R. I W } \\
3 \text { miles north-northeast of Ojo del }\end{array}$ & $\begin{array}{l}\text { Mesaverde formation, basal sandstone. } \\
\text { Mesaverde formation. } \\
\text { Dakota (?) sandstone. }\end{array}$ & $\begin{array}{l}1.89 \\
2.09 \\
2.12\end{array}$ & $\begin{array}{l}28.32 \\
13.71 \\
22.72\end{array}$ \\
\hline 404 & $\begin{array}{l}\text { Espiritu Santo ranch house. } \\
\text { Ojo del Espiritu Santo grant, where the }\end{array}$ & Dakota (?) sandstone................ & 2. 18 & 17.89 \\
\hline 403 & Ojo del Espiritu Santo grant............ & Morrison formation, sandstone near & 2.20 & 16. 26 \\
\hline 405 & SE. $1 / 4$ sec. 11, T. 20 N., R. 1 W........ & $\begin{array}{l}\text { middle of Los Bancos section, p. } 33 \text {. } \\
\text { Morrison formation, sandstone near } \\
\text { top. }\end{array}$ & 2.77 & 13.93 \\
\hline
\end{tabular}

Along the head of the Arroyo Bernalillito, in T. 15 N., R. 1 W., there are several springs that yield a supply of potable water. A sample of water collected from these springs was lost in transit so that no analysis could be made. The water probably comes largely from the Dakota (?), but some of it may come from the Morrison formation.

\section{CRETACEOUS SYSTEM}

\section{UPPER CRETACEOUS SERLES}

DAKOTA (?) SANDSTONE

The Dakota (?) sandstone forms the west slope of the hogback at the northwest end of San Pedro Mountain north of San Jose Spring. Farther south it is interrupted by faulting, but it reappears south of Nacimiento Creek, and thence to Los Bancos it forms the west slope of the outer hogback, in which it is exposed west of the Morrison formation. South of Los Bancos, where the westward dip decreases, the outcropping Dakota (?) swings around the south end of the Sierra Nacimiento and is terminated on the southeast side of the range, south of Mesa Blanca, by the Sierrita fault, which defines the eastern limit of the mountains.

The thickness and the character of the Dakota (?) sandstone vary considerably in this area. In San Miguel Mine Canyon (see sec. 11) the formation is 189 feet thick; in San Miguel Canyon (see sec. 12) it is 263 feet thick; near Senorito Canyon, in the SE. $1 / 4$ sec. 2, T. 20 N., R. 1 W. (see sec. 13), it is 191 feet thick. These sections are representative of the Dakota (?) along the central part of the 
range. In the southern part of the area the thickness is much less. Three-quarters of a mile east-northeast of the Ojo del Espiritu Santo ranch house it is 65 feet (see sec. 14), and it decreases in the vicinity of Los Bancos and farther south along the Arroyo Bernalillito to 25 feet.

The Dakota (?) sandstone consists of an upper and a lower member of sandstone with a shale member between. Both the upper and lower sandstone members are generally massive, and in general the basal sandstone is decidedly conglomeratic, containing pebbles that range mostly from a quarter of an inch to 1 inch in diameter and consist of quartz, jasper, chert, and quartzite, in a matrix of sand. In the SW. $1 / 4$ sec. 35 , T. 23 N., R. 1 W., the basal beds contain a considerable quantity of limestone pebbles. In general there is a definite bed of conglomerate at the base of the formation, but lenses and beds of conglomerate are also commonly distributed throughout the lower 50 feet. The medial shale member consists of black carbonaceous shale, shaly carbonaceous sandstone, and sandy shale; in many places it is not well exposed. The shale member was not observed south of the latitude of the Ojo del Espiritu Santo ranch house, as it has decreased in thickness and disappeared, and the entire Dakota (?) formation there consists of massive sandstone. In Sandoval County the color of the sandstone ranges from white through buff and tan to brown, and in places it contains lenses of red sandstone. The Dakota (?) in this region has been briefly described by Gardner ${ }^{31}$ and Darton. ${ }^{32}$

\section{Section of Dakota (9) sandstome in San Miguel Mine Canyon}

Mancos shale.

$$
\text { [Mean strike north, mean dip } 42^{\circ} \text { W.] }
$$

Dakota (?) sandstone:

Ft. in.

Sandstcne, fine to medium grained, with carbonaceous material (wood fragments) disseminated throughout and containing streaks of carbonaceous sandstone. Massive at base, medium to thin bedded at top. Deposits of sulphur on outcrop---

Mostly concealed. In other exposures this member is largely carbonaceous shale, sandy shale, and shaly carbonaceous sandstone

Sandstone, massive, with thin layers of grit and conglomerate; some carbonaceous sandstone

${ }^{31}$ Gardner, J. H., Coal between Gallina and Raton Spring, N. Mex., in the San Juan coal region: U. S. Geol. Survey Bull. 341, p. 338, 1909.

Darton, N. H., "Red Beds" and associated formations in New Mexico: U. S. Geol. Survey Bull. 794, pp. 122-124, 169, 1929. 


\section{Section of Dakota (9) sandstone in San Miguel Canyon}

[Beds dip $40^{\circ}-50^{\circ}$ W.]

Mancos shale.

Dakota (?) sandstone:

Feet

Upper sandstone member, buff, yellow, and mottled with stain of limonite, massive

Middle shale member and some of lower member; shale, sand, and sandstone; partly concealed.

Lower sandstone member, cream-colored to buff and

light red at base, massive, cross-bedded_......-.- 10

Morrison formation.

13. Section of Dakota (?) sandstone and upper part of Morrison formation in SE. $1 / 1$ sec. 2, T. 20 N., R. 1 W., north side of Senorito Canyon

Mancos shale, black, carbonaceous, sandy.

Dakota (?) sandstone:

Ft. in.

Sandstone, white; buff on weathered surface

Sandstone, buff on weathered surface; massive, friable

Sandstone, buff on weathered surface; massive; basal beds have mud cracks

Sandstone, same as next above but thin bedded_...... $\quad 4$

Shale, partly concealed, and soft sandstone.

Sandstone, massive, containing carbonaceous material and showing a reticulate pattern on weathered surface.

Sandstone, thin bedded, friable, containing much organic material; partly concealed.

Sandstone, massive, friable

Shale, thin bedded, carbonaceous, mostly concealed_--

Sandstone, massive, with thin seams of carbonaceous sandstone in top part; forms hogbacks

Sandstone, massive, with streaks of conglomerate

Shale, black, sandy, carbonaceous.

Sandstone, massive, with streaks of carbonaceous material

Morrison formation:

Sand, green, with streaks of green shale

Grit, coarse, quartzose

Sand, buff-yellow

Sandstone, white, massive, coarse, quartzose

Sandstone, whitish, soft

Sand, brown, soft, with streaks of red clay shale

Sand, buff-yellow and greenish, soft._..............-

Shale, red, green, and chocolate-colored 
Morrison formation-Continued.

Sandstone, grayish white, massive, fine grained; typical mottled appearance on weathered surface_-- 3

Shale, dark maroon, with a streak of yellow sand 5 feet thick in center. 32

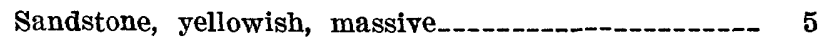

Sand, gray with streaks of green, coarse, soft

Lower part of Morrison cut out by a fault.

14. Section of Dakota (?) sandstone in the mesa three-fourths of a mile eastnortheast Ojo del Espiritu Santo ranch house

Mancos shale.

Dakota (?) sandstone: Feet

Sandstone, buff, massive, coarse grained

Sandstone, thinly laminated, cross-bedded, coarse grained_- 26

Sandstone; light buff with some green-tinted bands; mas-

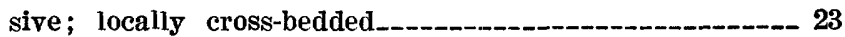

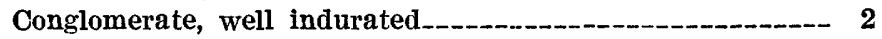

Morrison formation.

The Dakota (?) occupies so definite a stratigraphic position at the base of the Upper Cretaceous marine shales that correlations throughout this region may be made with fair confidence. No fossils were found in it in Sandoval County, but it is regarded as the base of the Upper Cretaceous series because of its position and character. No angular discordance was noted in this area between the Dakota (?) sandstone and the underlying Morrison formation, but there is a break between them representing a large part of Lower Cretaceous (Comanche) time.

The artesian prospects of the Dakota (?) sandstone are discussed on page 84, and this phase of the hydrology of the Dakota (?) will not be referred to here. The Dakota (?) sandstone in this area gives rise to numerous springs and seeps, chief among which are those on Arroyo Bernalillito, in T. 15 N., R. 1 W., and the one at the Ojo del Espiritu Santo ranch house. The analysis of the water at the Ojo del Espiritu Santo ranch house (see No. 5, p. 78) shows that the water in the Dakota (?) sandstone near its outcrop is somewhat hard but otherwise of good quality. It is entirely possible that soft water may be obtained from the Dakota (?) at a depth of several hundred feet.

Two samples of the sandstone were tested and found to have a porosity of 17.89 and 22.72. (See Nos. 404 and 407, p. 35.) These represent the typical sandstone, not the conglomeratic phases, which doubtless are more porous. However, even the degree of porosity indicated is sufficient to warrant the belief that the Dakota 
sandstone will prove to be a good water-bearing formation. In the localities where the Mancos shale is at the surface and where the alluvium along streams fails to yield water of satisfactory quality or in sufficient quantity it is recommended that wells be drilled to the Dakota (?) sandstone, provided the latter does not lie at so great a depth that it will involve excessive expenditure for drilling.

In the Catron well, at La Ventana, which was abandoned at 2,003 feet, the Dakota (?) sandstone yielded considerable water, as did also the beds of sand at higher and lower horizons. This water came within $\mathbf{1 5 0}$ feet of the surface. There is no record of the quality of the water.

Log of Catron well, at La Ventana, N. Me*.

[Driller's log. Formation names indicate probable correlation]

\begin{tabular}{|c|c|c|c|c|c|}
\hline & $\begin{array}{c}\text { Thiok- } \\
\text { ness } \\
\text { (feet) }\end{array}$ & $\begin{array}{c}\text { Depth } \\
\text { (feet) }\end{array}$ & & $\begin{array}{c}\text { Thick- } \\
\text { ness } \\
\text { (feet) }\end{array}$ & $\begin{array}{l}\text { Depth } \\
\text { (feet) }\end{array}$ \\
\hline $\begin{array}{l}\text { Mancos shale: } \\
\text { Adobe, brown } \\
\text { Sand, brown } \\
\text { Shale, blue } \\
\text { Sandy shale, blue. } \\
\text { Shale, blue, soft } \\
\text { Shale, blue... } \\
\text { Slate, brown, soft. } \\
\text { Sandy shale, brown } \\
\text { Shale, blue, } \\
\text { Lime, gray, hard } \\
\text { Slate, blue, soft } \\
\text { Shale, blue, soft. } \\
\text { Slate, blue, soft } \\
\text { Lime, gray, hard } \\
\text { Slate, blue, soft } \\
\text { Lime, gray, hard } \\
\text { Sand, gray, dry } \\
\text { Slate, white, soft } \\
\text { Lime, gray, hard }\end{array}$ & $\begin{array}{r}40 \\
37 \\
418 \\
9 \\
15 \\
39 \\
10 \\
17 \\
100 \\
5 \\
10 \\
12 \\
463 \\
5 \\
115 \\
5 \\
20 \\
15 \\
5\end{array}$ & $\begin{array}{r}40 \\
77 \\
495 \\
504 \\
519 \\
558 \\
568 \\
585 \\
685 \\
690 \\
700 \\
712 \\
1,175 \\
1,180 \\
1,29 \\
1,300 \\
1,320 \\
1,335 \\
1,340\end{array}$ & 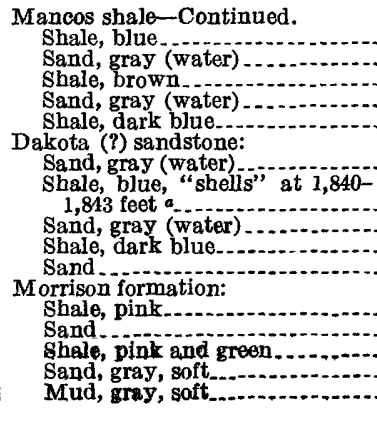 & $\begin{array}{r}310 \\
45 \\
10 \\
10 \\
75 \\
40 \\
\\
30 \\
30 \\
25 \\
10 \\
5 \\
15 \\
7 \\
40 \\
11\end{array}$ & $\begin{array}{l}1,650 \\
1,695 \\
1,705 \\
1,715 \\
1,790 \\
1,830 \\
1,860 \\
1,890 \\
1,915 \\
1,925 \\
1,930 \\
1,945 \\
1,952 \\
1,992 \\
2,003\end{array}$ \\
\hline
\end{tabular}

- The term "shells" probably refers to a thin hard bed. No fossil shells were noted at the surface in or near the Dakota (?) sandistone.

\section{MANCOS SHALE}

The Mancos shale crops out in a narrow but uninterrupted belt from the north margin of the area southward to La Ventana Mesa. In this area the beds either dip west at a high angle, are vertical, or are overturned toward the east, and the entire section is well displayed at many places. South of La Ventana Mesa the westward dip decreases and the width of the Mancos outcrop increases greatly, so that it is exposed in a belt several miles wide on the southwest margin of the area. At the south end of the Sierra Nacimiento, south of the Dakota (?) outcrop, it is at the surface, and the prevailing dip here is southward. It is also exposed east and southeast of Mesa Blanca. 
15. Section of Mancos shale in Senorito Canyon, in the NE. 1/4 sec. 11, T. $20 \mathrm{~N} .$, R. $1 \mathrm{~W}$.

Mesaverde formation.

Mancos shale :

Feet

1. Shale, dark gray, with abundant selenite in bedding planes and cracks. Upper third has many hard calcareous and siliceous concretionary bands from 6 inches to 3 feet in thickness, decreasing in amount and thickness near the base-

2. Sandstone, tan and buff, thin-bedded, generally not well indurated, interbedded with gray shale

3. Sandstone and shale, same as above except that it contains limestone beds less than 1 foot thick...-.-

4. Shale, dark gray, interbedded with thin tan sandstone in upper half; lower half concealed, but probably the same

5. Shale, dark grayish black, with interbedded thin fossiliferous limestone. Carlile fauna from this interval

6. Shale, black, thin bedded, carbonaceous

7. Sandstone, buff and tan, with hard concretionary band in center.

8. Shale, lower half black, grading up into tan and gray

9. Shale, dark gray, containing several beds of limestone less than 1 foot thick and thin sandstone about 40 feet from base.

Dakota (?) sandstone.

In Senorito Canyon, where section 15 was measured, the beds are overturned to the east, and it is possible that there may have been some shortening due to deformation, but it is believed that the section is approximately correct. The Mancos shale is prevailingly gray, and its weathered surface viewed from a distance appears cream-buff. The formation consists mainly of shale, but in places sandstone beds are rather abundant. South of La Ventana Mesa in the Ojo del Espiritu Santo grant and west of the Rio Salado south of the grant there are in the lower part of the formation several sandstone beds that form gently westward-dipping slopes, and farther west, in the Mesa Prieta, where higher beds are exposed, the soft buff sandstones that occur in the middle and upper part of the formation come to the surface. The sandstones of the middle and upper parts of the formation (beds 2,3, and 4), are not continuous over wide areas but grade into shale. The Mancos contains thin-bedded limestone in the middle and lower parts of the formation, and bed 5, which is abundantly fossiliferous, was found at every place where it was searched for. The Mancos everywhere in the area rests con- 
formably on the Dakota (?) sandstone as in other parts of the San Juan Basin. ${ }^{33}$

Fossils collected from bed 5 in Senorito Canyon (section 15) were identified as follows by J. B. Reeside, jr., who also furnished the memorandum as to their correlation.

Inoceramus fragilis Hall and Meek.

Inoceramus dimidius White.

Ostrea, small simple form.

Anchura ruida White.

Baculites gracilis Shumard.
Scaphites warreni Meek and Hayden. Prionotropis woolgari (Mantell). Prionotropis wyomingensis Meek. Prionotropis macombi Meek.

This lot contains a good representation of the widespread Carlile fauna, which is also found in a thin zone $\mathbf{3 0 0}$ to $\mathbf{5 0 0}$ feet above the base of the Mancos shale on the north side of the San Juan Basin and perhaps a little higher on the west side. In the Puerco Valley the collections made by Stanton and Lee show that it extends more than 1,000 feet above the base of the Mancos.

No fossils were collected in the lower 300 feet of the Mancos shale, but it is believed that the Greenhorn limestone horizon is probably represented.

Fossils were also collected 4 miles west-southwest of Cabezon from a limestone about 285 feet below the basal sandstone of the Mesaverde, which is there several hundred feet lower stratigraphically than the base of the Mesaverde at the place where section 15 was measured, owing to the thickening of the Mesaverde at the expense of the upper beds of the Mancos. This westward thickening of the Mesaverde at the expense of underlying and overlying beds is discussed on pages $43-45$ and illustrated diagrammatically in Figure 3. A list of the fossils with a memorandum from J. B. Reeside, jr., follows:

Cucullaea n. sp.

Inoceramus sagensis Owen.

Ostrea aff. O. elegantula newberryi.

Placenticeras sp. undetermined, with stout blunt nodes.
Tellina equilateralis Meek and Hayden. Gyrodes n. sp. aff. G. conradi Meek. Volutoderma sp., internal casts.

This is a lower Montana (Telegraph Creek and Eagle) fauna which occurs at the top of the Mancos shale of the western part of the San Juan Basin but some $\mathbf{7 0 0}$ feet below the top on the north side.

The data given above clearly establish the stratigraphic position of this shale formation in the Upper Cretaceous succession and serve as a basis for correlation with strata in the Rocky Mountains and adjacent country.

The Mancos shale is in general not water-bearing, but some of the beds of sandstone and sandy shale yield small to moderate supplies. Among the wells obtaining water from sands in the Mancos shale

\footnotetext{
${ }^{38}$ Reeside, J. B., jr., Upper Cretaceous and Tertiary formations of the western part of the San Juan Basin, Colo. and N. Mex. : U. S. Geol. Survey Prof. Paper 134, p. 9, 1924.
} 
are the A. C. Fish 105-foot drilled well, in the NW. 1/4 sec. 35, T. 23 N., R. 1 W., and the Frank Mahan 75-foot drilled well, in the NW. $1 / 4$ sec. 26, T. 23 N., R. 1 W., the shallow dug wells at Cabezon, in T. 16 N., R. 3 W., and the 286-foot drilled well of Mr. Ash near

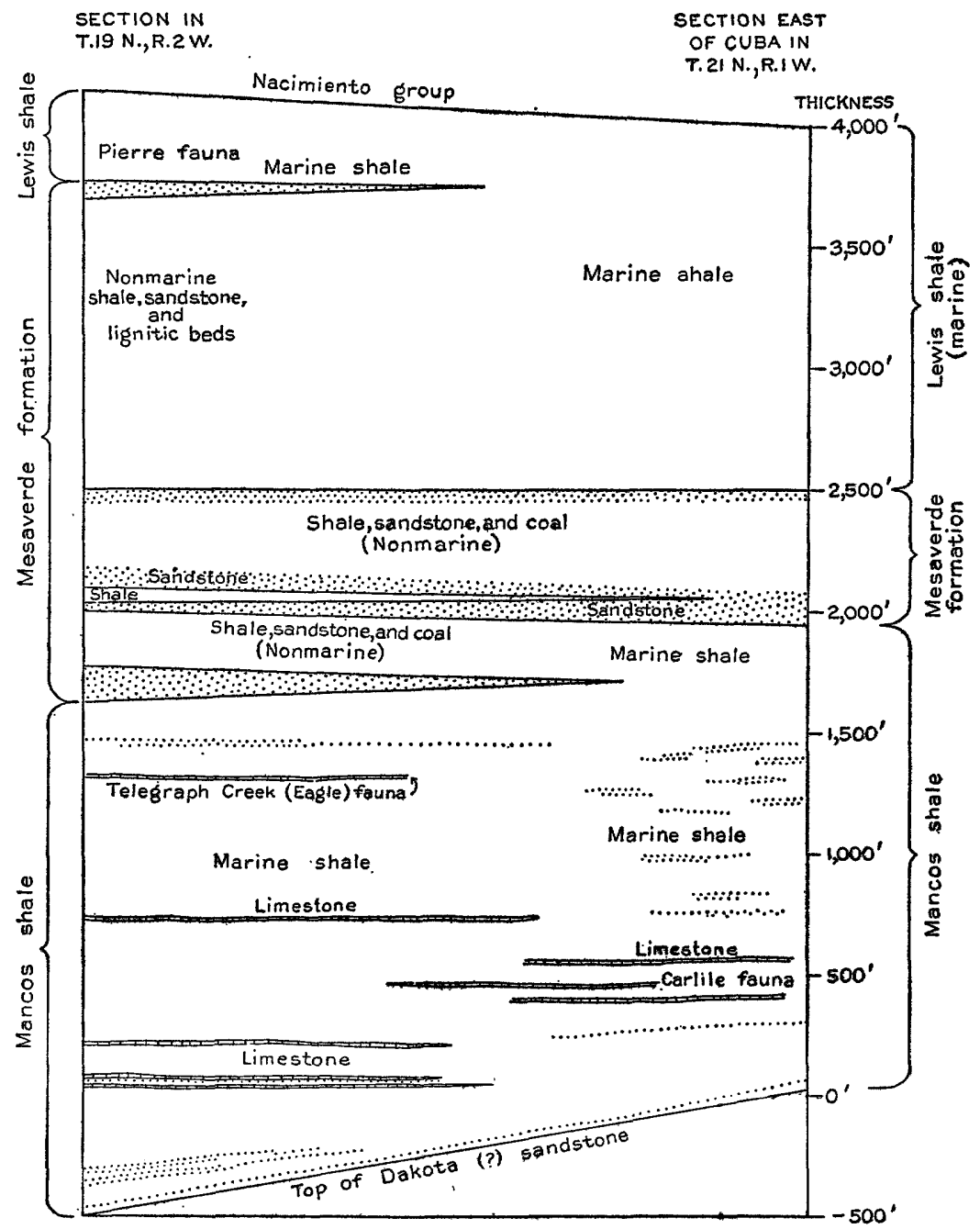

FIGURE 3.-Diagram showing the relations of the Mesaverde formation to the Lewis and Mancos shales

the head of Arroyo Bernalillito, in the SE. 1/4 NE. 1/4 sec. 24, T. $15 \mathrm{~N} .$, R. $2 \mathrm{~W}$. The water of all these wells is highly mineralized. The water obtained from the Mancos shale come entirely from the sandy phases of the formation and is hard, highly mineralized, and generally unsatisfactory for domestic use, but in most places it can be used for watering stock and for irrigation. In the Catron 
well, at La Ventana (see $\log$, p. 39), the sandstone from 1,650 to 1,695 feet and from 1,705 to 1,715 feet, which in all probability belongs to the Mancos, yielded a considerable supply of water, but the chemical character of the water is not known.

\section{MESA VERDE FORMATION}

From the Sandoval-Rio Arriba County line southward to a point beyond Senorito Canyon the Mesaverde formation crops out in a narrow strip paralleling the mountain. The beds stand almost vertical in this area. Between Senorito and San Miguel Canyons the strike changes from approximately north to northeast. The south end of La Ventana Mesa marks the limit of the Mesaverde rocks east of the Rio Puerco; here the basal beds cross the river, and they are well exposed west of the Puerco in T. 18 N., R. 2 W., in the southeastern part of T. 19 N., R. 2 W., the northwestern part of T. 17 N., R. 2 W., and in T. 17 N., R. 3 W.

The three divisions of the Mesaverde that were recognized by Holmes ${ }^{34}$ and later named by Collier ${ }^{35}$ in ascending order the Point Lookout sandstone, the Menefee formation, and the Cliff House sandstone can not be correlated with the divisions of the Mesaverde recognized in this area.

East of Cuba the Mesaverde formation consists of an upper and a lower sandstone member and a middle coal-bearing group of rocks, in all about 560 feet thick. The thickness of these members is shown in section 16. A view of the Mesaverde is given in Plate 6, $A$.

16. Section of Mesaverde formation measured east of Cuba, in the $\$ E$. $1 / 4$ sec. $35, T .21$ N., R. 1 E.

Lewis shale.

Mesaverde formation:

Ft. in.

Upper sandstone member: Sandstone, mostly white, with some buff, massive, medium grained. Weathering produces a reticulate pattern on bedding planes

37士

Middle coal-bearing member:

Shale, brown, lignitie; contains impressions of twigs and stems. In some places this unit grades into a thin-bedded carbonaceons shale and in others there is a workable coal bed at the top

8andstone, thin beds of buff and white_._._.... $14 \quad 6$

Shale, brown, lignitic, thin bedded; like the shale

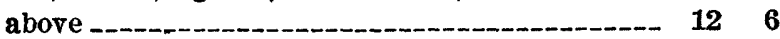

Sandstone, buff on weathered surface, massive_._ 2

a Holmes, W. H., Geological report on the San Juan district: U. s. Geol. and Geog. Survey Terr. Ninth Ann. Rept., p. 252, 1877.

${ }_{25}$ Collier, A. J., Coal south of Mancos, Montezuma County, Colo.: U. S. Geol. Survey Bull. 691, pp. 296-297, 1919. 


\section{Mesaverde formation-Continued.}

Middle coal-bearing member-Continued.

Sand, cream-colored, not indurated_._._....... 16

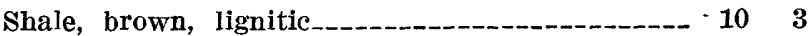

Sand, gray. Partly concealed__________._. 86

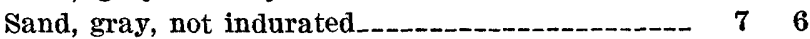

Siliceous bed containing branches, twigs, etc_.... 1

Shale, brown, lignitic, with some black carbonaceous bands

Sand, gray and buff

Shale, chocolate-brown, sandy. Partly concealed_

Sandstone, carbonaceous

Shale, black and brown, lignitic, with bands of

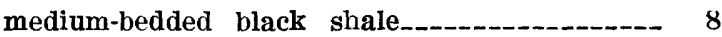

Sandstone, buff, medium grained.............. 5

Shale, chocolate-brown to black, fissile__._._...- 2

Shale, light brown and tan

Concretionary band, buff, siliceous_-_________-_ $\quad 10$

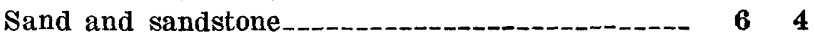

Shale, mostly gray, some cream-colored. Partly concealed.

Sand, cream-colored _._.

Shale, black carbonaceous, brown lignitic, and

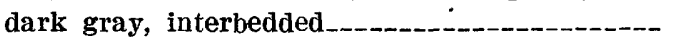

Sandstone, cream-colored to buff, medium bedded-

Shale, black carbonaceous, brown lignitic, and gray, interbedded _._..._-_._- 20

Sand, buff to cream-colored....-...--

Shale, black carbonaceous and brown lignitic, with streaks of gray shale and sand__._._._. 24

Sandstone, buff _. 5

Concretionary band, siliceous_____._-_-_-_ 8

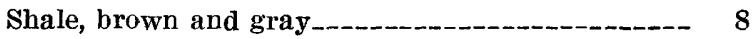

Sand and sandstone, light gray to white $\ldots$

Shale, gray and brown, fissile; streaks of sand near base

Total thickness of middle coal-bearing mem-

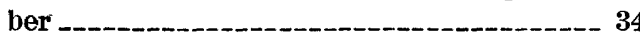

Lower sandstone member:

Sandstone, white, massive, more or less indurated ;

buff on some of weathered surfaces.

Sandstone, white to light gray, medium grained, generally incoherent with some cemented beds_- $\mathbf{7 4}$

Sand, white and gray, thin bedded, incoherent_-_ 37

Sandstone, white, medium grained, massive; buff

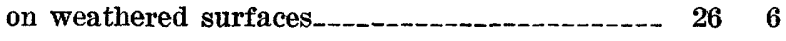

\begin{tabular}{l} 
Total thickness of basal sandstone-... \\
Total thickness of Mesaverde formation \\
\hline $\begin{array}{ll}563 & 10\end{array}$
\end{tabular}

Southward from Cuba the Mesaverde increases greatly in thickness, owing to the fact that the marine shales in the lower part of the 
Lewis shale and the upper part of the Mancos shale grade toward the southwest into fresh and brackish water deposits. These deposits consist of sandstone, carbonaceous shale, and coal. The several members represented in section 17 indicate that the total thickness of the Mesaverde is more than 2,100 feet. Section 17, A, shows that there are in the western part of T. 19 N., R. 1 W., about 1,250 feet of beds equivalent to the Lewis shale on the north, which are to be regarded as Mesaverde. The shales in the lower part of this section were probably deposited in brackish water, but the beds occupying the same position west of the Rio Puerco in T. 19 N., R. 2 W., are partly of fresh-water origin and are lignite bearing. The sandstone at the top of section 17, A, which east of the Rio Puerco has been mapped as the top of the Mesaverde, grades westward into a massive cliff-forming sandstone. The upper and lower sandstone members and the middle coal-bearing member are represented in section 17 , B, C, and D. In the southern part of T. 20 N., R. 1 W., sandstones and fresh-water lignitic beds begin to appear in the upper part of the Mancos. These beds were measured in the bluffs east of La Ventana and found to consist of a coal-bearing group of rocks about 328 feet thick, given as section $17, \mathrm{E}$, and a basal sand about 145 feet thick, given as section 17, F. The basal sand rests on the marine Mancos. The interfingering relation of the Mesaverde with the Mancos and Lewis is shown diagrammatically in Figure 3. From the foregoing statements it is evident that the Mesaverde-Lewis and MesaverdeMancos contacts have been drawn across time equivalents. This is not unusual with deposits of this type.

17. Sections of Mesaverde formation in T. 19 N., R. 1 W.

A. Along the road in secs. 8, 16, and 17

[Time equivalent of basal Lewis shale east of Cuba]

Sandstone, massive, cliff forming. On the west side of the Rio Puerco this sandstone thickens rapidly and gives rise to the dip slope of Mesaverde in secs. 22, 23 , and 24, T. 19 N., R. 2 W

Shale, dark, and sandstone, interbedded. The sandstone beds increase in thickness to a maximum of 3 feet at the top. This is a transition zone from the shale below to the sandstone above

Ft. in.

Shale, dark gray to blackish gray, mineralized; contains thin streaks of sand.

Shale, dark gray, with a few thin beds of flagstone and cross-bedded sandstone $1 \pm$ foot thick

Shale, dark gray ; contains less than one-fourth sand and beds of thin flagstone

Shale, blackish gray and tan-gray, sandy, with many beds of sandstone less than 4 feet thick 


\section{B. SE. $1 / 4$ sec. 17}

[Equivalent of upper sandstone member east of Cuba] Ft. in.

Sandstone, buff-yellow, massive, cliff forming__._._._. 55

\section{Near line between secs. 17 and 20}

[Equivalent of middle coal-bearing member of Mesaverde formation east of Cuba]

Coal, partly concealed.

Ft. in.

Sandstone, gray, with four streaks of carbonaceous sandstone 6 inches to 10 inches thick distributed at about equal distances. 2 Concretionary band, iron-stained.

Shale, black

Coal, mostly bone exposed

Shale, black, with three or four beds of bone coal 10 to 12 inches thick

Sandstone, buff-yellow and gray, thin bedded

Coal, bone, and black shale, interbedded..............

Shale, black, carbonaceous, sandy

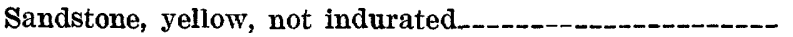

Sandstone, thin bedded, carbonaceous_._-_...-...--

Sandstone, tan, with carbonaceous streaks_........-.-.

Shale, black, carbonaceous, sandy at top._...-.....-.

Shale, dark gray

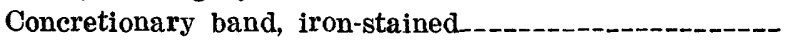

Sandstone, cream-colored, not indurated...........-.-.

Shale, dark gray and chocolate-colored; upper 1 foot sandy

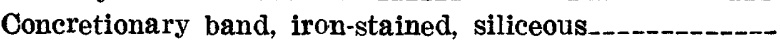

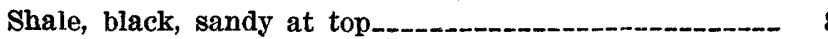

Sandstone, yellow, soft, cross bedded, lenticular._._..... 4

Shale, tan, sandy at base, grading up into gray argillaceous shale

Sandstone, massive, soft, gray to buff on weathered surface; lower 10 feet cross-bedded, lenticular............ Shale, gray and black, carbonaceous; partly concealed_.Concealed by alluvium. A quarter of a mile to the northeast these beds are the same as those next above. Sandstone, yellow to cream-colored, massive__._._._._._. Shale, brown and tan, sandy at top

\section{NE. $1 / 4$ see. 20}

[Equivalent of basal sandstone of Mesaverde east of Cuba]

Sandstone, massive, gray ; cream-colored on weathered surface. The carbonaceous beds below are channeled considerably. Thickness is approximate 


\section{E. Fastern part of secs. 29 and 32}

[Lower coal-bearing member, time equivalent of upper part of Mancos shale east of Cuba]

Shale, dark gray and tan-brown, with a few thin beds ( 1 to 2 feet thick) of dark-brown carbonaceous shale and bone

Ft. in.

Shale, brown, sandy

Sandstone, zellow-buff and yellow-green, massive; locally cross-bedded; medium grained; $\tan$ on weathered surface.

Shale, gray

Sandy silt, buff-yellow

Shale, gray, with brown sandy beds

Sandstone, brown, thin bedded

Shale, gray-brown and gray-green, with streaks of lignitic material

Sandstone, buff, thin bedded.

Shale, dark gray

Sandstone, buff, thin bedded.

Shale, black and gray

Sandstone, tan, massive, medium grained

Coal, bony, and thin black carbonaceous sandstone, interbedded

Shale, black, sandy, with wood fragments throughout. One streak of coal 2 inches thick 18 inches from base

Silt, gray, tan, and greenish brown, with concretionary layers

Coal, bony, and black shale

Silt, gray, sandy, with some thin iron-stained concretionary bands

Silt, tan, sandy

Sandstone, buff, massive, with some soft beds_..._......- 14

Silt, buff, sandy_-_._- 1

Shale, brown, lignitic-_-_-_.-

Coal, bony _-_ 1

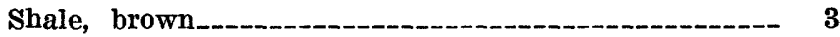

Sandstone, cream-colored to buff; generally incoherent.

Some massive resistant beds

Coal, in part bony

Shale, brown, lignitic, interbedded with black shale

Concretionary band, siliceous, iron stained at top......-

Sandstone, gray, medium grained, buff on weathered surface

Sandstone, thin bedded, carbonaceous

Shale, black

Coal

Shale, black

Sandstone, thin bedded, argillaceous_._.

Coal (La Ventana), apparently same as working at mine 
Eastern part of secs. 29 and 32 -Continued

Sandstone, thin bedded, soft, with lignitic and carbonaceous seams

Ft. in.

Concretionary band, brown, siliceous

Shale, brownish black

Sandstone, light gray, massive, medium grained; buffyellow on weathered surface

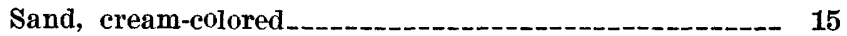

Sandstone, massive, medium grained, buff-tan on weathered surface.

Shale, brown, lignitic, with streaks of carbonaceous sandstone

Coal, with considerable bone; not well exposed

Shale, brown, lignitic

Sandstone, tan to gray, massive, medium grained. Some small beds of carbonaceous material

F. Ojo del Espiritu Santo grant, south of sec. 33, T. 19 N, R. 1 W.

[Basal sandstone of Mesaverde formation; time equivalent of upper part of Mancos shale east of Cuba but below $\mathrm{E}]$

Sandstone, gray, thin-bedded, medium grained, with carbonaceous seams and carbonized wood and twigs; weathers brown.

Ft. in.

Sandstone, gray stained with brown; massive, cliff forming; medium grained, locally cross-bedded.

Sandstone; thin-bedded, with sand and sandy silt; gray, tan, buff, yellow, and orange

$\begin{array}{r}98 \\ \hline 145 \\ \hline\end{array}$

Total thickness of Mesaverde formation $2,137+$ Mancos shale.

A section measured 1 mile north of Copper City by Gardner ${ }^{36}$ shows that the Mesaverde there is 719 feet thick. However, from this place northward the Mesaverde thins, and in the central part of T. 22 N., R. 1 W., is probably not over 250 feet thick, but south of the Rio Arriba-Sandoval County line it thickens again.

No fossils were found in the Mesaverde in this area, though some of the sandstone beds might be expected to carry marine forms.

so Gardner, J. H., The coal field between Gallina and Raton Spring, N. Mex., in the San Juan coal region: U. S. Geol. Survey Bull. 341, p. 345, 1909. 
The coal-bearing beds of the Mesaverde were not studied in detail, but for the information of those interested the following analyses are given.

Analyses of coals from the Mesaverde formation in the vicinity of La Vientana

[Analyses by U. S. Bureau of Mines]

\begin{tabular}{|c|c|c|c|c|c|c|}
\hline \multirow[b]{2}{*}{ Location } & \multirow[b]{2}{*}{$\begin{array}{c}\text { Mois- } \\
\text { ture }\end{array}$} & \multirow[b]{2}{*}{$\begin{array}{l}\text { Volatile } \\
\text { matter }\end{array}$} & \multirow[b]{2}{*}{$\begin{array}{l}\text { Fixed } \\
\text { carbon }\end{array}$} & \multirow[b]{2}{*}{ Ash } & \multicolumn{2}{|c|}{ Heating value } \\
\hline & & & & & Calories & $\begin{array}{c}\text { British } \\
\text { thermal } \\
\text { anits }\end{array}$ \\
\hline 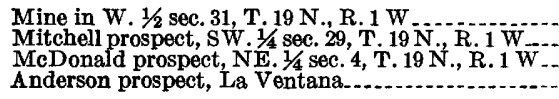 & $\begin{array}{l}11.2 \\
22.1 \\
17.7 \\
16.3\end{array}$ & $\begin{array}{l}39.8 \\
35.7 \\
35.0 \\
32.6\end{array}$ & $\begin{array}{l}46.3 \\
37.7 \\
42.5 \\
43.8\end{array}$ & $\begin{array}{l}2.7 \\
4.5 \\
4.8 \\
7.3\end{array}$ & $\begin{array}{l}6,522 \\
4,883 \\
5,728 \\
5,794\end{array}$ & $\begin{array}{r}11,740 \\
8,790 \\
10,310 \\
10,430\end{array}$ \\
\hline
\end{tabular}

The Mesaverde formation, at least in the southern part of the area, where it crops out, contains more water-bearing sandstone than any other group of rocks in this area and is one of the principal aquifers of the region. The samples analyzed (Nos. 413, 416, and $418, \mathrm{p} .35$ ) show that the porosity ranges from 13.71 to 28.32 per cent; the prevailing porosity of the sandstone is probably nearer the larger figure. Some of the coal beds will probably also prove to be water bearing. The Mesaverde in T. 19 N., R. 2 W., gives rise to a number of springs, the water from which is of good quality though somewhat hard. Among these may be mentioned the spring of O. K. Ash, in the NE. 1/4 NW. 1/4 sec. 26. (See p. 78.)

. Where the Lewis shale is at the surface and satisfactory supplies of water can not be readily obtained it is recommended that wells be drilled through into the Mesaverde, provided that formation is not so far below the surface that the cost of drilling to reach it will be excessive. Although the shallow ground water in the Mesaverde formation is hard, it is entirely possible that water obtained from a depth of several hundred feet will be softer. The artesian prospects. of the Mesaverde formation in several parts of the area are discussed on page 84 .

\section{IEWIS SHAIE}

The Lewis shale crops out in a narrow continuous belt from the Rio Arriba-Sandoval County line to the southern part of sec. 11, T. $21 \mathrm{~N}$., R. $1 \mathrm{~W}$., where the belt begins to widen as the dip becomes more gentle. There the strike changes from north to northeast, and the outcrop crosses the Rio Puerco in Tps. 20 and 19 N., R. 1 W. The 
shale is well exposed west of the Rio Puerco in the central part of T. 19 N., R. 2 W.

The Lewis shale is a dark-gray shale of marine origin containing numerous siliceous and calcareous concretionary beds, the latter generally not exceeding 3 feet in thickness, and a few thin impure limestone beds. There is little sandstone in the formation except in T. 20 N., R. 1 W., where it grades into the Mesaverde formation. A section measured from the Mesaverde contact in sec. 2, T. 20 N., R. $1 \mathrm{~W}$., to the base of the Puerco formation in sec. 4, gave a thickness of about 1,660 feet. West of the Rio Puerco in the central part of T. 19 N., R. 2 W., where the Mesaverde has thickened at the expense of the Lewis shale (see fig. 3) the thickness of the Lewis probably does not exceed 400 feet. This westward thinning of the Lewis shale may also be due in part at least to the unconformity at its top. Gardner ${ }^{37}$ reports that farther north, near Gallina, it is 2,000 feet thick.

Fossils were collected from a thin limestone bed in the Lewis shale in sec. 5, T. 19 N., R. 1 W., about 200 feet above the sandstone mapped as the top of the Mesaverde formation at this place. They were identified by J. B. Reeside, jr., as follows:

Yoldia evansi Meek and Hayden.

Inoceramus sagensis Owen.

Pteria linguaeformis $\mathrm{E} \vee \mathrm{ans}$ and Shumard?

Syncyclonema rigida Hall and Meek.

Liopistha undata Meek and Hayden.

Tellina equilateralis Meek and Hayden.

The above list is a representative Pierre fauna, but according to Reeside ${ }^{38}$ the species alone do not separate it sharply from the Mesaverde, as most of them occur also in that formation.

The Lewis shale consists almost entirely of clay shale except where it grades into the underlying Mesaverde, and it is a poor waterbearing formation. The well of S. Zambrano, in the NW. 1/4 sec. 20, T. 19 N., R. 2 W. (see p. 99), obtains water of inferior quality from a bed of sandy shale near the base of the Lewis. The Bletcher well, near the mouth of Senorito Canyon, in T. 20 N., R. 1 W., probably obtains most of its water from the alluvium, but the well apparently extends into the Lewis. Its water is of better quality than is to be expected from any well that might obtain its entire supply from the Lewis shale. If in drilling through the Lewis shale into the Mesaverde formation water is encountered in the Lewis it should be cased off, as it is almost certain to be highly mineralized.

${ }^{37}$ Gardner, J. H., op. cit., p. 339.

ss Reeside, J. B., jr., written communication. 


\section{TERTIARY SYSTEM}

\section{EOCENE SERIES}

\section{PUERCO AND TORREJON FORMATIONS}

The name Nacimiento group was introduced by Gardner ${ }^{39}$ to include the Puerco ${ }^{40}$ and Torrejon ${ }^{41}$ formations. Wortman showed that the vertebrate faunas of these formations are quite different. Gardner states that the formations are separated by an erosional unconformity, but he adds : ${ }^{42}$

The unconformity between the Puerco and Torrejon formations can not be noted in the field except on fossil evidence. It is highly probable that it is one essentially of overlap with very little stratigraphic break. The two formations are so closely similar in lithologic character that it is difficult to distinguish one from the other without the assistance of fossils.

The fossils collected from the Nacimiento group have been listed by Gardner, ${ }^{43}$ who points out that they consist mostly of vertebrates, among which mammalian forms are the most numerous. Bones of reptiles and an undetermined bird are represented. The Puerco has yield some fresh-water mollusks. Gardner's paper contains a historical account of the names Puerco and Torrejon, together with a complete list of the fossils that have been collected along the Rio Puerco.

The rocks of the Nacimiento group are regarded as lower Eocene and the approximate equivalent of the Fort Union formation of the northern Great Plains. A view of these rocks as exposed in the northeastern part of T. 21 N., R. 1 W., is given in Plate $6, B$.

The accompanying geologic section (No. 18) of the Nacimiento group along the Rio Puerco, after Gardner, ${ }^{44}$ shows that this group is about 840 feet thick. The writer found that the Nacimiento group at the south end of the range, in secs. 5 and 8, T. 14 N., R. 1 E., is about 820 feet thick.

\section{Section of Nacimiento group along the Rio Puerco southwest of Nacimiento [Cuba]}

[Measured by J. H. Gardner]

Wasatch formation.

Unconformity.

Nacimiento group:

Torrejon formation:

Feet

1. Shale, variegated

20

2. Sandstone, brown

${ }^{30}$ Gardner, J. H., The Puerco and Torrejon formations of the Nacimiento group: Jour. Geology, vol. 18, pp. 702-741, 1910; The coal fields between Gallup and San Mateo, N. Mex.: U. S. Geol. Survey Bull. 341, pp. 364-378, 1909.

${ }^{10}$ Cope, E. D., Report on the geology of that part of northwestern New Mexico examined during the field season of 1874 : Chief Eng. Ann. Rept. for 1875, Appendix G, ch. 6, 1875.

41. Wortman, J. L., and Matthew, W. D., A revision of the Puerco fauna: Am. Mus.

Nat. Hist. Bull., vol. 9, p. 260, 1897.

4 Gardner, J. H., op. cit. (Jour. Geology), p. 722.

48 Idem, pp. 727-730.

4 Idem, p. 717 . 
Nacimiento group-Continued.

Torrejon formation-Continued.
3. Shale, gray
4. Sandstone, gray
5. Shale, gray, and soft sandstone
6. Sandstone, tan, massive__._. 15
7. Shale, yellowish
8. Sandstone, soft, coarse, tan, massive_-_-_-_- 120
9. Shale, gray
10. Sandstone, tan, massive, soft__._. 30
Total Torrejon formation

Feet

Puerco formation :

11. Shale and soft sandstone_____._._. 30

12. Shale, dark, carbonaceous_____._._._._._. 10

13. Shale, gray _....._. 10

14. Sandstone, yellowish, massive, lenticular.....- 10

15. Shale, rariegated._-_._- 25

16. Shale, dark, carbonaceous__-_-_-_ 4

17. Shale, chiefly yellowish

18. Sandstone, brown, massive, lenticular

19. Shale, variegated, and soft gray sandstone_-_-- 200

20. Sandstone, brown, massive, coarse grained.---- 40

21. Shale, gray, and soft sandstone_-_-_-_._-_-_ 45

22. Shale, very dark, local coal streaks____._.

23. Shale and soft sandstone, gray and tan__..... 90

Total Puerco formation
Total Nacimiento group_-

Unconformity.

Lewis shale.

In the lower part of the Puerco formation as defined by Gardner there is a massive cliff-forming sandstone which gives rise to a very prominent northward-sloping mesa. This is probably bed 20 of section 18. Recent work by C. H. Dane ${ }^{45}$ on the south side of the San Juan Basin has shown that this sandstone is the Ojo Alamo sandstone of Bauer ${ }^{46}$ and Reeside. ${ }^{47}$ West of Cuba there is another escarpment-forming sandstone which is apparently bed 8 of Gardner's section. This has been traced westward by Dane into similar sandstone and conglomerate, which were classed by Reeside and Bauer as the basal part of the Wasatch formation. The writer had accepted in the field the older classification of Gardner, but according to Dane certain tracts in the northwestern part of the area shown on the map as Puerco and Torrejon may include in places some beds of Wasatch age. Perhaps beds lower than 10 of Gard-

\footnotetext{
45 Personal communication.

${ }^{45}$ Bauer, C. M., Stratigraphy of a part of the Chaco River Valley : U. S. Geol. Survey Prof. Paper 98, pp. 275-276, 1916.

${ }^{4}$ Reeside, J. B., jr., Upper Cretaceous and Tertiary formations of the western part of the San Juan Basin, Colo. and N. Mex.: U. S. Geol. Survey Prof. Paper 134, p. 30, 1924.
} 
ner's section should now be included in the Torrejon formation, but the writer has not attempted to decide whether the division between the Puerco and Torrejon formations should be made. (See pl. 10, A.)

The Puerco formation contains a considerable amount of dark carbonaceous shale and silt. Associated with the shales are ironstained concretionary bands. The Torrejon formation in general contains less dark carbonaceous shales and more of tan, buff, and gray. At the south end of the Sierra Nacimiento, in the northeastern part of T. 14 N., R. 1 W., there are beds of the Nacimiento group which contain impure coal that has been prospected at several places.

In the southern part of the area mapped by the writer, in the northeastern part of T. $14 \mathrm{~N}$., Rs. $1 \mathrm{~W}$. and $1 \mathrm{E}$., beds considered to belong to the Nacimiento group lie on the Mancos shale, thus indicating a considerable unconformity at the base of the group.

The Nacimiento group as defined by Gardner contains a considerable amount of water-bearing sandstone that has about the same porosity as the sandstones of the Mesaverde formation. The shallow well of G. E. Conlisk, in the NE. $1 / 4$ sec. 31 , T. 20 N., R. 2 W., yields water that contains only 79 parts per million of dissolved solids. (See No. 2, p. 78.) This water, which comes from the sandstone represented by bed 20 of Gardner's section, is superior in quality to any other. found in the entire area. A number of shallow wells dug into the Puerco formation in the vicinity of Cuba yield water that is hard but on the whole not inferior in taste. The water obtained in shallow wells dug into beds of the Nacimiento group is generally though not always hard, but it is probable that water at a depth of several hundred feet is softer. It is entirely possible that some of the shale beds in the Nacimiento group will yield water of inferior quality, but if water of this character is obtained it should ke cased off and the well should be drilled down to lower sandstone strata in this group. The writer recommended that a well several hundred feet deep be drilled at Cuba in search for a more adequate water supply. (See p. 2.) The possibility of obtaining artesian water from the Nacimiento group in the San Jose Valley is referred to on page 84 .

\section{WASATCF FORMATION}

The Wasatch formation crops out in the western parts of Tps. 23, 22, and 21 N., R. 1 W. It is well exposed in many of the arroyos leading out from San Pedro Mountain. (See pl. 6, B.) Younger beds of the Wasatch crop out west of the area mapped, and the total thickness has therefore not been determined, but as exposed in this area it is at least several hundred feet. The formation is characterized by a basal conglomerate, which contains pebbles and cobbles of quartz, 
quartzite, and sandstone, and in places an abundance of shale pebbles. The pebbles range from half an inch to 5 inches in diameter, and the matrix is generally sand. The conglomerate as a whole is buff in color, but it weathers to a brown in some places. Above the basal conglomerate there is a great thickness of variegated sandy shale. In the northern part of the area along the Rio Puerco no beds of coal or lignite were noted in the Wasatch, but at the south end of the Sierra Nacimiento several thin clinker beds were observed. A section of the basal conglomerate of the Wasatch follows.

19. Section of basal conglomerate of Wasatch formation in NW. $1 / 4$ sec. 2 , T. 15 N., R. 1 W.

Wasatch formation:

Shale.

Basal conglomerate member:

Feet

Sand, yellow

Sandstone, cream-colored to buff, coarse grained, thin bedded.

Sandstone and conglomerate, predominantly coarsegrained sandstone; creamy yellow to buff. Conglomerate pebbles mostly quartzose, the largest 4 inches in diameter. (The top of this bed might be considered to be the top of the basal conglomerate)

Sand and shale interbedded; gray, green, yellow, and buff

Conglomerate and coarse sandstone interbedded. Pebbles in conglomerate dominantly quartzose, but also some of sandstone and shale, half an inch to 5 inches in diameter.

Nacimiento group (probably all Puerco formation):

Shale, dark gray, black, and chocolate-brown, grading

up into green

Sand and shaly sand, buff

Impure lignite with typical "somber beds" below.

Gardner ${ }^{48}$ considered that the Wasatch truncated the upturned outcrop of all younger formations, as shown by the following statement:

Steeply inclined strata limit the older sedimentary rocks along the boundary of the Nacimiento Mountains [San Pedro Mountain], the dips decreasing westward toward the interior of the San Juan Basin. Near the mountains this inclination varies from $35^{\circ}$ north of Gallina to more than $90^{\circ}$ at Copper Oity and northward. In the latter district the fold is overturned and dips $70^{\circ}$. toward the mountains. All the sedimentary formations above the Jurassic have this inclination with the exception of the Wasatch. About 10 miles north-

28 Gardner, J. H., op. cit. (Jour. Geology), pp. 720-721. 
west of Gallina the Wasatch has an inclination of about $\mathrm{S} .10^{\circ} \mathrm{W} . * * *$ The dip in that vicinity is apparently local and is of more recent date than any uplift in the Nacimiento Mountains, as shown by the fact that the Wasatch beds rest nearly horizontally against the crystalline rocks of these mountains between Gallina and Nacimiento [Cuba].

It is evident that there is an erosional unconformity at the base of the beds here mapped as Wasatch, and there may have been some minor warping prior to their deposition, but detailed work along San Pedro Mountain shows conclusively that the Wasatch, like the underlying formations, dips westward at a high angle, as much as $90^{\circ}$ in places. (See sec. $B-B^{\prime}$, pl. 1.) Plate $6, B$, shows the Wasatch and Nacimiento group standing almost vertical in secs. 2 and 11, T. 21 N., R. $1 \mathrm{~W}$. Likewise at the south end of the Sierra Nacimiento, where it rests on the Nacimiento group, it dips $50^{\circ}$ to $70^{\circ}$, and in a general way the strike is conformable with the underlying formations, though there are slight variations. Reeside ${ }^{49}$ points out that the Wasatch rests unconformably on the Torrejon in the southern part of the San Juan Basin without noteworthy stratigraphic hiatus, but in the northern part it apparently rests conformably on the Torrejon. .

Cope ${ }^{50}$ was the first to describe fossils from the Wasatch along the Rio Puerco. Most of the forms are mammalian vertebrates, but some reptiles also occur. Granger ${ }^{51}$ also made collections in the area, and Matthew ${ }^{52}$ has given a list of the Wasatch fossils in the San Juan Basin and a bibliography of publications relating to the Wasatch formation.

The water from shallow wells in the Wasatch formation is similar in quality to that obtained from shallow wells in the Nacimiento group. It is generally hard but potable and satisfactory for most uses. There are several wells of this type along the upper part of the San Jose and its tributaries. The massive basal sandstone and conglomerate of the Wasatch formation will doubtless prove to be the best water-bearing part of the formation because it is the most porous. The rocks lying above consist mostly of variegated sandy shales, which though less porous will probably also yield water. In fact, wells drilled into the Wasatch formation at any place in the upper San Jose Valley should yield supplies of water. The writer recommends that the basal sandstone of the Wasatch in the vicinity of La Jara be prospected for artesian flows. (See p. 2.)

\footnotetext{
4 Reeside, J. B., jr., op. cit., p. 46.

50 Cope, E. D., op. cit., pp. 1008-1017.

61 Granger, Walter, On the names of lower Eocene faunal horizons of Wyoming and New Mexico : Am. Mus. Nat. Hist. Bull., vol, 33, pp. 201-207, 1914.

62 Matthew, W. D., Faunal lists of the Tertiary Mammalia of the West: U. \$. Geol. Surrey Bull. 361, pp. 92-95, 1909.
} 


\section{MIOCENE AND PLIOCENE SERIES}

\section{SANTA FE FORMATION}

The Santa $\mathrm{Fe}$ formation was first described by Hayden ${ }^{53}$ in the vicinity of Santa $\mathrm{Fe}$ and was called the Santa Fe marls. Cope ${ }^{5 *}$ referred to the distribution of the Santa $\mathrm{Fe}$ beds between the Sangre de Cristo Range and the Sierra Nacimiento. In these beds on the east flank of the Jemez Mountains Cope found remains of the threetoed horse, dog, antelope, rhinoceros, mastodons, rats, birds (vultures), and tortoises. On the basis of the species of horse he correlated the Santa Fe formation with the so-called "Loup Fork," which included beds of Miocene, Pliocene, and Pleistocene age and which has since been divided into several units. More recently Osborn ${ }^{55}$ has regarded the species that have been found in the Santa $\mathrm{Fe}$ beds as transitional from the Miocene to the Pliocene.

The Santa $\mathrm{Fe}$ formation in this area varies greatly in character and thickness from place to place. West of Jemez Pueblo it consists mostly of white sand. (See pl. 7, A.) In the Santa Ana Mesa. where a thickness of at least 1,500 feet is exposed, there are alternating beds of sand, conglomerate, and sandy shale, and the prevailing color is red. In the valley of Jemez Creek between San Ysidro and Bernalillo, where the deposit is most extensively exhibited, it consists of alternating lenticular beds of conglomerate, sand, sandstone, and sandy shale, and the prevailing color is light tan, but some parts are red.

About half a mile southwest of Upper Canones, in an area of about half a square mile, there are some beds that are regarded as Santa $\mathrm{Fe}$ but that differ in character from most of the Santa $\mathrm{Fe}$ formation. They rest on the Abo sandstone and Chupadera formation and consist of about 65 feet of conglomeratic beds which at the base contain weathered boulders 10 inches in diameter, most of them of fine-grained igneous rock. These coarser beds grade into fine arkosic conglomerate and arkose, which in turn grade upward into well-indurated thin-bedded fine-grained flaggy sandstone about 100 feet thick. These beds are faulted against the Magdalena group and are greatly deformed.

Some beds regarded as Santa Fe in a small hill near the corner of secs. $8,9,16$, and 17, T. 13 N., R. 4 E., are also of rather exceptional character. The hill consists chiefly of beds of fine conglomerate,

${ }^{53}$ Hayden, F. V., Preliminary field report of the U. S. Geological Survey of Colorado and New Mexico: U. S. Geol. and Geog. Survey Terr, Third Ann, Rept., pp. 66-67, 1869.

54 Cope, E. D., op. cit., pp. 986-987.

5o Osborn, H. F., Equidae of the Oligocene, Miocene, and Pliocene of North America, iconographic type revision: Am. Mus. Nat. Hist. Mem., new ser., vol. 2, pt. 1, pp. 3, 34, 1918. 
grit, and sand (mostly quartzose and well rounded), about 300 feet in all. Unlike the typical Santa Fe, the individual beds are persistent and not lenticular and most of them contain a considerable. amount of basalt, much of which is glassy and scoriaceous, in the form of fragments that range from a fraction of an inch to almost 1 foot in diameter. The larger fragments of basalt generally occur in definite beds and are mostly confined to the lower third of the section. The sedimentary beds in this hill are cut by dikes that range from 1 to 10 feet in diameter, and the strata are deformed; the strike ranges through $180^{\circ}$ and the dip from $0^{\circ}$ to $20^{\circ}$. Presumably the deformation is due, in large part at least, to the intrusion of the dikes. It is uncertain whether or not the fragmental basalt in the sediments or in the later dikes that cut them may becorrelative with the basalt that caps Santa Ana Mesa and the adjoining hills. Near the southeastern margin of this hill there is a more or less circular intrusion of basalt about 100 feet in diameter at thebase, which Herrick ${ }^{58}$ considered a volcanic neck. A very prominent dike extends from it toward the west.

Along the railroad about 3 miles north of the railroad bridgeacross the Rio Grande, in the Santa Fe formation, there is a clastic dike about 6 feet wide, which consists of material of the Santa $\mathrm{Fe}$ formation that has been injected into the overlying strata. Lithologically the material of the dike is similar to that of the inclosing rock. The structure of the beds in the dike simulates the axis of a sharply flexed anticline. Jenkins ${ }^{57}$ describes the mode of origin of clastic dikes in eastern Washington and gives a bibliography of other occurrences.

In the Santa Ana Pueblo grant, west of the highway and about 2 miles south of the pueblo, there are several ridges composed of arkosic sand that has been cemented by calcium carbonate. On the exposed surface the sandstone of these ridges is weathered into. botryoidal and reticulate forms. The contact with the adjacent softer rock is obscured by a cover of sand, but the material composing the ridges apparently differs only in the presence of the carbonate cement. A definite conclusion as te its origin has not been reached, but it may have been formed by cementation along local zones or fissures by ground water.

The relation of the Santa Fe formation to the Wasatch is shown in the northern part of T. 14 N., R. 1 E., where the contact is exposed. There is no considerable difference in the strike and dip.

\footnotetext{
so Herrick, C. L., The geology of the environs of Albuquerque, N. Mex.: Am. Geologist, vol. 22 , pp. $26-43,1898$.

57 Jenkins, O. P., Mechanics of clastic dike intrusion: Eng. and Min. Jour.-Press, vol. 20, p. 12, 1925 ; Clastic dikes of eastern Washington and their geologic significance: Am. Jour. Sci., 5th ser., vol. 10, pp. 234-246, 1925.
} 
of the two formations, but a great thickness of Wasatch was eroded prior to the deposition of the Santa Fe formation, as the basal conglomeratic beds of the Santa Fe lie on lower Wasatch beds.

Along Jemez Creek there are terrace deposits consisting largely of redeposited material from the Santa Fe formation, and at the southeast end of the Sierra Nacimiento northwest of San Ysidro, there are terrace deposits resting on the Santa Fe formation made up of redeposited material from the Santa Fe as well as detrital material from the mountains. On the geologic map these terrace deposits are not separated from the deformed Santa Fe. The Santa $\mathrm{Fe}$ is the youngest formation involved in the folding and faulting that resulted in the uplift of the Sierra Nacimiento and San Pedro Mountain. (See p. 77.)

As there is a considerable variation in the lithologic character of the Santa $\mathrm{Fe}$ formation both laterally and vertically, there is also. a variation in the ground-water conditions in this formation in different parts of the area and at different stratigraphic positions. The ground-water conditions, therefore, can not everywhere be predicted. Along the valley of Jemez Creek the United States Indian Service has drilled a number of successful wells at Jemez, Santa Ana, and Sia. The water from these wells is probably derived in part from the Recent alluvium and in part from the Santa Fe formation; in the Jemez well some of the water may also be contributed by undetermined older formations obscured by the Santa $\mathrm{Fe}$ beds in this faulted valley. Analyses 7, 8, and 9 (p. 78) show that the water from the Jemez and Santa Ana wells is hard and contains from 628 to 933 parts per million of dissolved solids. The water from all these wells is used by the Indians and has a good taste. On La Ceja Mesa, which lies much higher than the valley of Jemez Creek, it is probably several hundred feet to water-bearing beds in the Santa $\mathrm{Fe}$ or older formations.

\section{HIGH-LEVEI GRAVEL}

In some places at an altitude as high as 8,600 feet, there are considerable deposits of well-rounded stream gravel. The pebbles are predominantly siliceous, consisting of quartz, quartzite, agate, jasper, decomposed granite, and volcanic rock. They range from the size of a pea to 4 inches in diameter. That these deposits have been transported for a considerable distance is shown by the fact that the pebbles are well rounded and that although in places they rest on limestone they contain few if any limestone pebbles. It is possible that stream gravel occurs at a higher altitude, but the deposits at an altitude of about 8,600 feet antedate the major uplift and are 
older than the oldest gravel of the mountain pediments. They are therefore probably of late Pliocene age and are here tentatively included within the Tertiary system.

On the plateau in the north-central part of sec. 25 and the southcentral part of sec. 36, at an altitude of about 8,800 feet and less, the old surface of pre-Cambrian and Magdalena rocks is covered with a grit of rounded siliceous pebbles about the size of a pea. This material is believed to have resulted from the weathering of the basal beds of the Magdalena group and possibly also of the Abo sandstone, which consists of such material. It rests on and is associated with decomposed granitic material from the pre-Cambrian. Also associated with this conglomeratic and arkosic material are limestone pebbles that are believed to have been derived from the Magdalena at some higher altitude. These materials are in large part at least younger than the high-level river terrace gravel described in the preceding paragraph.

\section{QUATERNARY SYSTEM}

\section{PLEISTOCENE SERIES}

PEDIMENTS

Along the west slope of San Pedro Mountain and also to a less extent along the west slope of the Sierra Nacimiento there are welldeveloped mountain pediments. ${ }^{58}$ These surfaces slope westward at an angle of $1.5^{\circ}$ to $3^{\circ}$. Newberry, ${ }^{59}$ when visiting this region in 1859 , was interested in these features as shown by the following passage from his report:

Near our camp are buttes and messas, several hundred feet in height, composed of yellow sandstones of Canyon Largo, of which the summits are thickly strewn with boulders of red granite and limestone, evidently washed down from the neighboring mountain before the intervening valley had been cut out by the stream which now flows through it. The amount of erosion indicated by the presence of this local drift where it is now found is enormous. I previously noted the same phenomenon in many localities among the foothills of the northern mountains.

The pediments of the Papago country, described by Bryan, contain a relatively thin veneer of detrital material in transit, with much of the bare rock surface exposed, on the upper part, adjacent to the

s Bryan, Kirk, Erosion and sedimentation in the Papago conntry : U. S. Geol. Survey Bull. 730, pp. 52-65, 1920 .

${ }^{60}$ Newberry, J. S., in Macomb, J. W., Report of the exploring expedition from Santa Fe, N. Mex., to the junction of the Grand and Green Rivers of the great Colorado of the West in 1859 , p. 116, 1876 .

3616-31-5 
mountain; their lower parts, adjacent to the valley, are covered with a considerable thickness of gravel and detrital material. In western Sandoval County the pediments are covered throughout with gravel from 5 to 30 feet thick, the amount not increasing on the lower. part of the slope as it does in the Papago country and other arid: regions. Pediments with a considerable cover of detrital material extending to the base of the mountain have also been described by. Bryan, ${ }^{60}$ who considers that a cover of this kind is characteristic of mountain regions with heavier rainfall, as the mountain streams with. larger volumes are able to supply a great quantity of material to the pediments at a rate equal to or faster than it is transported by the stream to which they are tributary. That there has been vigorous. stream action across the pediments in western Sandoval County is shown by the fact that these pediment surfaces persist across the upturned edges of older rocks of unequal hardness where the mountain streams developed a smooth, even surface, without protuberances, independent of the character of the older rocks. Adjacent to the mountains an alluvial fan of very recent geologic date gen-. erally overlies the pediment.

Along the west flank of San Pedro Mountain there are pediments at several levels. The best-preserved ones lie about 150 feet above the present streams near the mountains but are lower near the mouths of the streams. One of these is in secs. 25 and 26, T. 21 N., R. 1 W.; another extends out from the mountain on the north side of La Jara Creek in secs. 27, 32, and 33, T. 22 N., R. 1 W.; and between Cuba and Regina there are remnants of numerous other pediments at the same. level. In secs. 14 and 15, T. 21 N., R. 1 W., there is a pediment slope. which stands at the same general level, but it is not so high above the near-by stream; this gentle slope, which merges into the valley. on the east, has been cleared except immediately adjacent to the mountains and is cultivated, giving rise to a prosperous farming com:munity in the vicinity of Vallecito del Rio Puerco.

Remnants of older pediments stand at levels between 350 and 650 , feet above the streams. They doubtless record former periods of erosion during the elevation of the mountains.

Southeast of Cuba the pediments adjacent to the mountains have. been dissected and many of them have been almost completely destroyed by subsequent erosion.

West of the sharp ridge north of La Sierrita there is a well-devel-. oped pediment sloping westward, away from the mountains. The deposits of this pediment have been cemented to a large extent by

\footnotetext{
${ }^{60}$ Bryan, Kirk, San Pedro Valley, Ariz., and the geographic cycle . [abstract] : Geol. Soc. America Bull., vol. 37, pp. 169-170, 1926.
} 
calcium carbonate from the waters of springs, which were once plentiful along this front of the mountains.

Along the southeast slope of the Sierra Nacimiento, between San Ysidro and Canones, there are several well-developed mountain pediments and remnants with associated contemporary terraces. There is an especially well-developed one about $11 / 2$ miles north of San Ysidro that extends from the Sierrita fault nearly to Jemez Creek. For a mile or more west of Jemez Creek, between Upper and Lower Canones, there are remnants of pediments at several levels which doubtless record several different stages of the elevation of the mountains along the fault.

\section{TERRACES}

There are terraces along the principal streams, such as the Rio Grande, the San Jose, the Rio Puerco, the Rio Salado, and Jemez Creek. The deposits of the terraces along the tributaries to the Rio Puerco, the Rio Salado, and Jemez Creek grade into the deposits of the mountain pediments. The material composing these terrace and pediment deposits has the same composition except that closer to the mountain it is coarser.

At several places along the Rio Puerco flat-topped terraces stand 75 to 150 feet above the present flood plain, but they are best developed where the stream crosses the outcrop of relatively soft beds, such as the Wasatch shales along the San Jose north of La Jara, the Lewis shale in the southern part of T. 20 N., R. 1 W., and the Mancos shale south of La Ventana. These terraces are covered by 1 to 10 feet of gravel. The predominant material is red-brown granite in subangular fragments, as much as 6 or 8 inches in diameter, associated with a considerable amount of chert, quartz, and quartzite, the fragments of which are smaller and more rounded. Sandstone and limestone pebbles are locally present in noticeable amounts, and there are generally. some fragments of schist and basic igneous rock from the pre-Cambrian.

Between Cuchillo Blancho and Arroyo Penasco, along the stream that is tributary to the Rio Salado, the terraces are somewhat different from those along the Rio Puerco. The deposits contain essentially the same materials, but those east of the stream are cemented largely by calcium carbonate deposited from the waters of thermal springs that were active in past geologic time (see p. 63) and also to some extent by gypsum. Some of the deposits west of the stream are apparently cemented almost entirely by gypsiferous material from the near-by Todilto formation. The terrace deposits on the east side of the stream grade into the alluvial deposits and into the pediment. 
From a point about three-quarters of a mile west of San Ysidro westward for a mile or more, north of the road, there is a terrace that stands 130 to 150 feet above the flood plain of the Rio Salado. 'The terrace is covered by about 25 feet of compact conglomerate, the cement of which is calcium carbonate deposited by the waters from extinct springs. Traces of these springs are visible on the southwest slope of La Sierrita ; and their descendants issue along the road in the southwest end of La Sierrita. The terrace material grades from coarse conglomerate with cobbles 6 to 8 inches in diameter down to fine grit. The coarse material consists mostly of angular and subangular fragments of granite with some dioritic rock from the pre-Cambrian of the near-by mountain. The conglomerate contains well-rounded cobbles of sandstone, shale, chert, and quartz, which are smaller than the granite and grade down to fine grit. The finer-grained phase of the conglomerate is predominantly quartzose.

Along Jemez Creek between Upper and Lower Canones there are terraces that stand 100 to 150 feet above the river. These terraces contain material similar to that of the terraces already described, also an appreciable amount of basalt, diorite, and rhyolite from the near-by Tertiary rocks. The black basalt or dioritic boulders, some of which exceed 2 feet in diameter, are plentiful over the surface and are characteristic of the Jemez Creek drainage basin, none being observed along the Rio Salado or the Rio Puerco.

In the vicinity of Jemez Creek, between San Ysidro and the Rio Grande, there are terraces at several levels within the outcrop of the Santa Fe formation, which consist of material derived largely from the Santa Fe formation. These terraces were not studied in detail.

The present investigation extended as far as the Rio Grande only in the vicinity of Bernalillo, and the terraces adjacent to that stream were not investigated in detail, but it is apparent that between 30 and 40 feet above the river there is a well-developed terrace covered with well-rounded quartzose conglomerate.

WATER IN PEDIMENT AND TERRACE DEPOSTTS

The pediment and terrace deposits in general have not been prospected for ground-water supplies, but they are largely composed of permeable material that should yield water where it is saturated. Unfortunately, many of the terrace deposits adjacent to streams are relatively thin and are considerably above the water table, so that they are not to be considered as a source of water. The deposits on the pediments are also thin, but some of these pediment deposits adjacent to the mountains may prove to be water bearing to some extent. 


\section{PLEISTOCENE AND RECENT SERIES}

\section{THERMAL SPIING DEPOSITS}

At a number of localities along the flanks of the Sierra Nacimiento there are craters of travertine and similar thermal spring deposits. Some of this material cemented the gravel in the pediments and terraces. The oldest of the thermal spring deposits was formed in Pleistocene time, when these springs were most active, but some of the deposits are of Recent age, and springs are actively depositing at the present time. The spring deposits are very extensive at the south end of La Sierrita, along the Rio Salado, and between Arroyo Cachana and the Sierra Nacimiento overthrust. They are described more fully on pages 86-88. (See also pls. $8, B$, and 10,B.)

\section{RECENT ALLUVIUM}

Along all the larger streams and their tributaries there are deposits of alluvium, the character of which varies considerably from place to place. Along the Rio Puerco it consists largely of silt derived from the early Tertiary and Cretaceous rocks, but there are included lenses of conglomerate consisting mainly of harder rock from the near-by sandstones and from the older rocks of the mountains. Along Jemez Creek, sand makes up the greater portion of the alluvium, but there is also a considerable amount of conglomerate. The sand is contributed largely from the Santa $\mathrm{Fe}$ formation and the conglomerate from the harder rocks of the mountains as well as from the Santa Fe formation, which contains a considerable amount of conglomerate. The alluvium along the Rio Salado consists mostly of sand and silt with a minor amount of conglomerate. In the flood plain of the Rio Grande, the alluvium consists of sand and silt with a considerable amount of well-rounded conglomerate, which occurs at lenses in the finer deposits.

In most of the valleys, the alluvium along the flood plain has been dissected, so that the present stream flows in a trench. The time at which the streams in the arid Southwest ceased to deposit alluvium and began to dissect their flood plains is the subject of a recent paper by Bryan. ${ }^{61}$ Some information regarding the date of trenching by the Rio Puerco was obtained by the writer.

Throughout its length the Rio Puerco has cut a channel in the alluvial deposits of the flood plain. The width and depth of this channel increase from the headwaters downstream. In the vicinity of Cabezon the trench averages about 40 feet in depth and about 150

oryan, Kirk, Date of channel trenching (arroyo cutting) in the arid Southwest: Science, new ser., vol. 62, pp. 338-344, 1925 . 
feet in width. Mr. R. T. Heller reports that when he came to Cabezon, in 1889, the Rio Puerco flowed in a trench only about 5 feet wide, across which there was a bridge. He estimates that the water was about 6 feet below the bridge. It is reported that at that time there was probably more water than now and that during times of high water the stream spread over its present flood plain, which no longer happens. From these facts it is evident that although the Rio Puerco had begun to dissect its flood plain prior to 1889 , by that date it had cut only a relatively shallow trench, and the main dissection has taken place since 1889. This is consistent with the information furnished by Bryan, who points out that many of the arroyos in southern Arizona began to be dissected between 1880 and 1890 . It is probable that Jemez Creek has dissected its flood plain within the last 40 to 50 years.

The alluvium along the valley bottoms is an important source of ground water, but the quantity and quality of water obtained from this source vary considerably. The alluvial gravel along the Rio Grande yields water abundantly; analysis 10 (p. 78) shows that the water contains 782 parts per million of dissolved solids and though hard is satisfactory for most uses. The water from wells in the alluvium along Jemez Creek contains about the same amount of dissolved mineral matter, but the content of salt is greater; analysis 6 of water collected at San Ysidro shows 693 parts per million of dissolved solids. The alluvium along the upper Rio Puerco, though it bears a considerable quantity of water, is not so good an aquifer as that along Jemez Creek, as the water is more mineralized; the water has an unpleasant taste and, as shown by analysis 3, contains 2,708 parts per million of dissolved solids. Any water obtained from alluvium along streams will almost certainly be hard.

\section{IGNEOUS ROCKS}

In this area there are igneous rocks of two types-rhyolite and basalt. These two rocks are not in contact where they were observed in the area, and their relations were not determinable.

In western Sandoval County no fossil-bearing beds are associated with the igneous rocks, hence their exact age can not be established. The following facts, however, bear on their age: They lie on the Santa $\mathrm{Fe}$ formation, and though the Santa $\mathrm{Fe}$ is involved in the deformation that resulted in the uplift of the Sierra Nacimiento and San Pedro Mountain, the rhyolite and rhyolite tuff which flank the mountains on the east are not deformed and hence were not involved in this movement. The age assigned to the Santa $\mathrm{Fe}$ is Miocene and Pliocene, but as it seems hardly probable that the rhyolite and basalt are as late as Pleistocene the writer is inclined to regard them as of 
late Pliocene age, and they are so classified in this report. Herrick and Johnson, ${ }^{62}$ and also Lindgren, Gordon, and Graton ${ }^{63}$ consider these basaltic eruptive rocks overlying the Santa Fe as marking the final stage of the Tertiary.

\section{BASALT .}

There are two principal areas of basalt in the area studied-one in the southeastern part and the other in the southwestern part. The basalt in the southeastern part of the area is best displayed in the Santa Ana Mesa, which is a part of the great body of eruptive rocks east of the Sierra Nacimiento. The basalt in the southwestern part of the area appears in the Mesa Prieta, the Mesa Chivato, and the peaks along the Rio Puerco that represent the eastern extension of the Mount Taylor volcanic field. Neither area is in proximity to the region of acute deformation adjacent to the mountains.

\section{SANTA ANA MESA AND ENVIRONS}

The Santa Ana Mesa is a broad undulating table-land underlain by basalt, through the southwest edge of which Jemez Creek has cut a gorge, leaving an isolated mesa in the northwestern part of T. 13 N., R. 4 E. The basalt, which rests on the Santa Fe formation, is in general a black massive rock 25 to 200 feet thick, but in places there is more than one flow, and the tops of individual flows are scoriaceous.

The base of the basalt is about 1,000 feet higher in the southeastern part of T. 15 N., R. 3 E., than it is in the northwestern part of T. 13 N., R. 4 E. This seems to be due largely to the difference in relief of the prebasalt surface. That this surface was irregular is shown by the fact that there are exposures which show that the molten basalt cascaded over cliffs at least 50 feet in height, the flow at the top of the cliff being continuous with that at the bottom. This great sheet of basalt was probably erupted largely from volcanoes to the east, but here and there dikes of basalt were noticed. There are some especially noteworthy dikes in sec. 17, T. 13 N., R. 4 E.

\section{MESA CHIVATO}

The Mesa Chivato was not investigated, but as this mesa is intimately related to the Mesa Prieta it will be referred to briefly here. At the west edge of the Mesa Chivato is Mount Taylor, or San

\footnotetext{
${ }^{62}$ Herrick, C. L., and Johnson, D. W., The geology of the Albuquerque sheet: New Mexico Univ., Hadley Lab. Bull., vol. 2, pp. 6 and 50, 1900.

63 Lindgren, Waldemar, Graton, L. C., and Gordon, C. H., The ore deposits of New Mexico: U. S. Geol. Survey Prof. Paper 68, p. 33, 1910.
} 
Mateo Mountain. Mount Taylor was first described by Newberry, ${ }^{64}$ who pointed out the fact that it is the crater of an extinct volcano. Later the region was studied in more detail by Dutton, ${ }^{65}$ who reported that although Mount Taylor stands upon the basalt-covered mesa, the basalt forming the mesa away from the base of the mountain was erupted largely through fissures and did not come from Mount Taylor. However, on the slopes and in proximity to the mountain there is much volcanic material that was erupted from this crater.

\section{MESA PRIETA}

The Mesa Prieta is situated mostly in Tps. 14 and 15 N., R. 2 W. The western edge of this mesa is about 8 miles east of the Mesa Chivato and separated from it by the valley of the Rio Puerco. The Mesa Prieta over most of its surface is capped with 100 to 200 feet of basalt. This basalt, though prevailingly massive, is scoriaceous in places. It was erupted through fissures or small volcanoes apart from Mount Taylor. The present valley of the Rio Puerco may represent a stretch where the basalt was thin; or the basalt of the two mesas may not have been continuous, a fact that was pointed out by Dutton. ${ }^{66}$

\section{PEARS IN THE IOWER RIO PUERCO VAILEY}

In the Rio Puerco Valley south and southwest of Cabezon village, between the Mesa Chivato and Mesa Prieta, there are a number of peaks, the largest of which is Cabezon. These peaks have been of interest to geologists since the time of the earliest explorations. Newberry saw them in 1859 and mentioned them in his report. ${ }^{67}$ Dutton ${ }^{68}$ also examined them and concluded that they are volcanic necks and represent former sources of eruption of the basalt equivalent in age to the flows that cap the Mesa Prieta and Mesa Chivato. Johnson ${ }^{69}$ described them in some detail. He regarded these peaks or buttes as true volcanic necks representing the material which remained in tubes or chimneys connecting with vents at some higher surface. He pointed out that the inclosing sediments into which they were intruded are generally not disturbed; that in many the basalt has a columnar structure that curves outward, which suggests a cooling surface at the top and at the sides of the plug adjacent to the inclosing sediments; that several of the plugs contain agglomerate,

6* Newberry, J. S., in Macomb, J. N., Report of the exploring expedition from Santa Fe, N. Mex., to the Junction of the Grand and Green Rivers of the great Colorado of the West in 1859 , pp. $61-62,1876$.

${ }^{05}$ Dutton, C. E., Mount Taylor and the Zuñi Plateau : U. S. Geol. Survey Sixth Ann. Rept., pp. 111-183, 1885.

Dutton, C. E., op. cit., p. 166.

ot Newberry, J. S., op. cit., p. 117.

${ }^{68}$ Dutton, C. E., op. cit., pp. 64-69.

68 Johnson, D. W., Volcanic necks of the Mount Taylor region, New Mexico: Geol. Soc. America Bull., vol. 18, pp. 303-324, 1907. 
some of which consists of baked fragments of the inclosing sedimentary beds, and that material of this type is to be expected in a volcanic conduit in which there have been explosive eruptions; that the numerous cones contain types of material that might be expected in a volcanic conduit from the surface down to a depth of several hundred feet; that subsequent erosion of the softer inclosing sediments left the more resistant basalt standing as an erosional remnant with the sediments lapping around it and forming its base.

The writer was mostly concerned with an examination of the structure of the sedimentary rocks along the Rio Puerco, with a view to determining their artesian possibilities, and as it was late in the season there was little time available for a study of the mode of origin of these peaks. In the descriptions of some of the peaks. which follow, Johnson's paper has been freely used.

Cabezon Peak.-The most spectacular peak in this area is Cabezon (pl. 3, $A$ ), which has long been a well-known landmark. Its summit is more than 8,000 feet above sea level and is reported to be about 2,160 feet above the valley bottom. The upper half of this peak is a more or less cylindrical mass of basalt, much of which is columnar; the lower half is a broad platform of sedimentary rocks, partly covered by talus and wash. The basalt is of several types, as indicated in the following section:

\section{Section of basalt on east side of Cabezon Peak}

[Thicknesses are estimated]

Summit of peak.

Red, purple, and black scoriaceous and cindery basalt

Dense black basalt, exhibiting well-developed exfoliation weathering.

Dense black basalt, greenish on weathered surface; zeolite bearing.

Alternating layers of dense black basalt and vesicular zeolitic basalt

Dutton ${ }^{70}$ did not climb Cabezon, but he concluded that it was a neck of origin similar to those that occur throughout the Rio Puerco Valley in this vicinity. Johnson ${ }^{71}$ points out that the sediments around the base are undisturbed and that the contact between the sediments forming the basal platform and the basalt is obscured by talus, but on the basis of his examination of the other peaks he concludes that Cabezon is a volcanic neck, and with this opinion the writer is inclined to agree. 
Cerro Chato.-About 2 miles southwest of Cabezon Peak there is a small flat-topped peak known as Cerro Chato, referred to as Butte No. 3 by Johnson, ${ }^{72}$ who wrote:

This butte is rudely cylindrical in cross section, is fairly flat-topped, of smaller diameter than Cabezon, and does not form so prominent a landmark as many of the others. On the eastern side the yellow and brown Cretaceous shales and sandstones are well exposed and are seen to be quite horizontal and little affected by heat. They may be traced to within less than 50 feet of the butte at this point, but the precise contact is obscured. $* * * A$ closer examination shows that in no exposure does the igneous rock rest upon the sediments; but large remnants of the sediments found well up toward the summit of this butte on other sides prove that the contact is essentially vertical. The internal structure of the butte is fairly typical of the greater number of those examined. It is found to be composed of a peculiar agglomerate consisting of angular or somewhat rounded fragnents of vesicular; generally reddish lava, loosely held together, often containing fragments of sandstone and shale, and shot through in all directions by great tongues or stringers of more massive columnar lava. The columns in this butte are often finely developed at right angles to the contact with the agglomerate, showing: that the liquid lava was the last to be intruded. Doubtless in many cases there have been several alternations of the two types of activity. The agglomerate suggests a more or less explosive phase of volcanic activity.

The agglomerate in Cerro Chato contains fragments of sandstone, some of them $1 \frac{1}{2}$ to 3 feet in diameter, which have been baked to a flintlike rock, but in many fragments the bedding is well preserved. At the south end of the butte a dike of basalt 200 feet thick, with north-south trend, cuts the well-indurated tuff and spreads out near the top of the peak.

La Abra de los Cerros.-About 4 miles southwest of Cabezon Peak there are two peaks which are separated by the Canada La Abra de los Cerros, and these peaks are themselves referred to as Abra de los Cerros. The northwest one is No. 4 of Johnson, ${ }^{73}$ and the southeast one is No. 5. In referring to the northwest peak, Johnson states that the butte is similar to Cerro Chato in being composed of both agglomerate and columnar basalt. The writer noted that in the west face there is about 150 feet of tuffaceous material or agglomerate, which is cut by a vertical dike of basalt 50 feet or more in width that spread out on top of the tuff. Some of the basalt is denseand black; some is vesicular.

Johnson's description of the southeast butte is as follows:

On the northern and western sides the yellow sandstones and shales (Mancos)" are beautifully exposed and show practically no disturbing effect of the intrusion. Gullies have cut back through the sediments to the butte, ending abruptly against the more or less vertical wall of igneous rock. These give peculiar niches or alleyways, flanked on either side by steep walls of horizontal

72 Johnson, D. W., op. cit., p. 312.

${ }^{78}$ Idem, p. 314. 
sediments, with a back wall of igneous rock formed by the side of the butte. The precise contacts are sometimes well shown and are seen to be essentially vertical. The sediments are usually cut off square without any evidence of disturbance whatever, but occasionally they show a slight dip away from the contact.

Cerro de los Cuates.-West of the Rio Puerco about 4 miles westnorthwest from Cabezon Peak is Cerro de los Cuates. This peak was not ascended by the writer. It apparently owes its existence to the presence of one or more dikes with a general north-sound trend. Extending for more than a mile northward from the base of this peak are two dikes. About $11 / 2$ miles north of the peak the dikes are from 1 to 3 feet wide and about 25 feet apart, and their prevailing trend is about N. $25^{\circ} \mathrm{E}$.

Cerro de las Chanisalas.-West of the Rio Puerco, about 2 miles southwest of La Abra de los Cerros and about 4 miles southwest of Cabezon, there is a small peak known as Cerro de las Chanisalas. This hill was seen only on the north and east sides, near the base. In the north face a dike of basalt with a trend north of east was observed; this dike seems to widen at the top of the peak.

Cerro Cochino.-Cerro Cochino is about $23 / 4$ miles east-northeast of the village of Guadalupe. It was not examined in detail. The mass of igneous rock which forms its summit indicates that in origin it is similar to the other peaks and that it probably represents either a volcanic neck or a dike.

Cerro Lopez.-About 2 miles east of the village of Casa Salazar there is a peak known as Cerro Lopez. This peak, which was observed only from the west side, apparently consists of a mass of intrusive basaltic rock which has a trend approximately north-south.

El Salado.-About 3 miles west of the village of Guadalupe there is a fair-sized peak known as El Salado, which was not visited.

\section{RHYOLITE AND RHYOLITE TUFF}

Overlying the Santa Fe formation in the northeastern part of the area is a great mass of rhyolite and rhyolite tuff, mostly tuff. This rock is cream-colored to white, but in it there are darker-colored beds, 50 feet or more thick, which consist of a massive lavendertinted rhyolite with phenocrysts of quartz. This rhyolite is not known to be ore bearing in this region, but rhyolite which is presumably of the same age contains considerable quantities of gold and silver in the Cochiti or Bland district ${ }^{74}$ to the east, where it has been broken and fractured and in some places faulted. East of Canones the rhyolite tuff rests on the Poleo sandstone, but farther up Canyon San Diego it extends across the Chupadera formation

${ }^{74}$ Graton, L. C., op. cit. (Prof. Paper 68), p. 153. 
(pl. 3, B) and Abo sandstone, and in one locality in the bluff west of Jemez Springs it rests on the Magdalena group. Some exposures of the rhyolite tuff resting on the Permian red beds in the Canyon San Diego are striking features. Graton ${ }^{75}$ and Larsen and Ross ${ }^{76}$ have found that this lava came from Redondo Peak, to the northeast. Away from the immediate proximity of the peak the rhyolite gives rise to a broad, flat-topped plateau, which extends west to the east flank of the Sierra Nacimiento. The canyons that dissect this plateau afford excellent exposures, and they show that the rhyolite was poured out on an eroded and previously deformed surface. East-southeast of Lower Canones the rhyolite tuff rests horizontally on deformed Triassic beds, thus showing that the rhyolite was erupted after the mountain-making deformation.

\section{WATER IN THE BASALT AND RHYOLITE}

No springs of importance were noted at the contact of the rhyolite or basalt with the sedimentary rocks in this area, but Gregory ${ }^{77}$ reports that the springs at the Hopi Buttes, in the Navajo county, occur at such contact. In the portion of Sandoval County shown on Plate 1 the basalt and rhyolite occupy high mesas, generally 1,000 feet or more above the nearest streams, so that in proximity to the streams the outcrops of these rocks are high above the permanent water table. However, so far as lithologic character is concerned these eruptive rocks are sufficiently porous to be good water-bearing beds, and it is very probable that away from the deeply trenched streams wells drilled into these rocks will yield supplies of water. In the mountains to the northeast there are numerous springs in the volcanic rocks.

\section{STRUCTURE}

\section{GENERAL FEATURES}

The dominant structural feature of the area described in this report is the mountain range comprising the Sierra Nacimiento and San Pedro Mountain. Newberry ${ }^{78}$ who was the first to describe it, pointed out that it consists of a core of granite covered in many places by Carboniferous limestones and that younger rocks ranging

75 Lindgren, Waldemar, Graton, L. C., and Gordon, C. H., The ore deposits of New Mexico: U. S. Geol. Survey Prof. Paper 68, p. 151, 1910.

7 Larsen, E. S., and Ross, C. S., unpublished manuscript.

${ }^{77}$ Gregory, H. E., The Navajo country, a geographic and hydrographic reconnaissance of parts of Arizona, New Mexico, and Utah : U. S. Geol. Survey Water-Supply Paper 380, p. $139,1916$.

${ }^{78}$ Newberry, J. S., in Macomb, J. N., Report of the exploring expedition from Santa Fe, N. Mex., to the junction of the Grand and Green Rivers of the great Colorado of the West in 1859, pp. 114-118, 1876. 
in age from Carboniferous to Tertiary are turned up on edge along the flanks of the granite axis. Cope ${ }^{79}$ described some of the structural features of San Pedro Mountain, and M. K. Shaler, ${ }^{80}$ referring to the steeply dipping rocks along the flanks of the mountains, said, "A fault whose extent and relations are not clearly understood trends north-south between the vicinity of Cuba and a point east of the southern end of the Nacimiento Range." Reagan's sections across part of the area ${ }^{81}$ show faulting along the Sierra Nacimiento. Gardner ${ }^{82}$ noted that in the northern part of the area the strata in proximity to the mountains are overturned and that farther away the westward dip decreases. Darton ${ }^{83}$ showed that a fault of considerable magnitude extends along the west side of the Sierra Nacimiento, and the writer has pointed out that this fault is an overthrust. ${ }^{84}$

Besides the faults, which are mostly close to the mountains, there are several flexures, most of which are a few miles from the mountains.

\section{FAULTS}

Sierra Nacimiento overthrust.-A major zone of faulting exists along the west slope of the Sierra Nacimiento and San Pedro Mountain. Most of the fault planes in this zone dip toward the east, showing that the mountain mass has been overthrust to the west, toward the San Juan Basin. This overthrust is not a single fault, but in several places the movement has taken place along several planes of shear. The name Sierra Nacimiento overthrust is suggested for this zone of faulting, and its principal features are shown in the cross sections in Plates 1 and 2.

The Sierra Nacimiento overthrust, unlike many of the other overthrusts in the Rocky Mountains, moved toward the west. It was initiated as a fault with the upthrow on the east, but as compressive forces were operating within the earth's crust a horizontal component of force as well as the vertical component was present. Therefore, when the pre-Cambrian granite and the relatively small amount of

${ }^{79}$ Cope, E. D., Report on the geology of that part of northwestern New Mexico examined during the field season of 1874 : Chief Eng. Ann. Rept. for 1875, Appendix G 1, pp. 10081017, 1875.

80 Shaler, M. K., Gypsum in northwestern New Mexico: U. S. Geol. Survey Bull. 315, pp. 260-265, 1907.

si Reagan, A. B., Geology of the Jemez-Albuquerque region, N. Mex. : Am. Geologist, vol. 31, pp. 68-110, 1903.

Gardner, J. H., The Puerco and Torrejon formations of the Nacimiento group : Jour. Geology, vol. 18, pp. 702-741, 1910.

8 Darton, N. H., Geologic structure of parts of New Mexico: U. S. Geol. Survey Bull. 726, p. 241, 1922; "Red Beds" and associated formations in New Mexico: U. 8. Geol. Survey Bull. 794, pp. 171-172, 1928 ; Stone, R. W., Gypsum deposits of the United States: U. S. Geol. Survey Bull. 697, p. 181, 1920.

84 Renick, B. C., The geology and artesian-water prospects in the San Jose-Rio Puerco Valley, in Sandoval County: New Mexico State Fngineer Seventh Bien. Rept., p. 72, 1926. 
overlying sedimentary rocks caught with it on the upthrown side of the fault were uplifted so that they came into contact with the soft Cenozoic, Mesozoic, and Paleozoic shales and sandstones, the preCambrian mass on the east side of the fault was rigid and the younger sedimentary rocks on the west side were incompetent and relatively much more easily deformed. The pressure resulting from the compressive stresses within the crust was no doubt released in the direction of least resistance-that is, toward the sedimentary rocks on the west-and the granite thus moved westward over the sedimentary rocks. The shale beds doubtless acted as a lubricant-for example, at several places the older beds slid on the Chinle shale as if it were a greased surface. (See p. 73.) At the north end of San Pedro Mountain, in sec. 25, T. 23 N., R. 1 W., rocks have been moved westward over younger rocks at least 1 mile (see pls. 1 and 2), and to the south the westward movement has been at least half a mile.

The stratigraphic displacement along this overthrust varies considerably. The maximum observed was 3,000 to 3,500 feet, which is less than that observed on the Jemez fault (p. 74). At many places the Permian, Jurassic (?), and Triassic formations rest against the pre-Cambrian, and in sec. 2, T. 21 N., R. 1 W., the Mancos shale rests against the Chupadera formation.

The most complex structure in the area is at the northwest end of San Pedro Mountain, especially in secs. 23, 24, 25, 26, and 36, T. 23 N., R. $1 \mathrm{~W}$, the details of which are shown in Plate 2. The predominant feature is a series of overthrusts from east to west, most of the fault planes dipping east at a relatively flat angle. In a hill in the SE. $1 / 4$ sec. 25 a succession of overthrusts repeats the lower Magdalena beds and the pre-Cambrian several times. In the SW. 1/4 sec. 25 and SE. $1 / 4$ sec. 26 there is still greater displacement, as the Magdalena strata are thrust westward over the Chinle (?) formation and the Chupadera formation has been brought against the Morrison. In the SE. 1/4 sec. 23 and extending northeastward across sec. 24 a fault which repeats the Todilto and Wingate outcrops may be a normal fault, but it is of a slightly earlier date than the overthrust faults on the west and has been offset by the overthrusting near the center of the western part of sec. 24. This zone of complicated overthrusting apparently ends in the southern part of sec. 36. For several miles farther south the structure is less complex.

In the eastern parts of secs. 23 and 26, T. 22 N., R. 1 W., there are two and possibly three fault planes along the Sierra Nacimiento overthrust belt. Along the westernmost of these the Senorito sandstone lentil has been thrust over the Mancos shale, both dipping $45^{\circ}$ to $90^{\circ} \mathrm{E}$.; along the next fault to the east the Chupadera formation 
rests against the basal Chinle (?) shales; and a short distance farther east the pre-Cambrian rests against the Chupadera formation, possibly by faulting or possibly by unconformable deposition.

In the NW. 1/4 sec. $24, T .21$ N., R. 1 W., Wingate sandstone is faulted against Mancos shale, the Mancos being on the west (downthrown) side. (See sec. $C-C^{\prime}$, pl. 1.) A short distance farther east the Chinle (?) shales and Senorito sandstone lentil have been thrust westward over the earlier fault, almost to the Mesaverde outcrop. Where the plane of this later fault is first exposed it dips east $75^{\circ}$ or more, but toward the west it flattens greatly, and it is practically horizontal where it crosses the earlier fault. The later fault is offset slightly along the south line of sec. 13, but the two faults join along the south line of sec. 24 . It appears likely that along the later overthrust the upper Chinle (?) shales have acted as a lubricant, so that the beds overthrust onto them have slid easily to the west. The Chinle (?) shales exhibit this property at a number of places along the Sierra Nacimiento overthrust, and it seems that where they are faulted the plane of overthrust generally has a flatter eastward dip than elsewhere.

In the northeast corner of T. $20 \mathrm{~N}$., R. $1 \mathrm{~W}$., the structure is complex, for in addition to the major overthrust, which here has a north-south trend, there are several other faults of less displacement. In this area (see sec. $D-D^{\prime}$, pl. 1) the displacement along the overthrust is considerably less than it is at most places along the range farther north. To the south, however, in secs. 13, 14, and 24, the faulting along the overthrust is en échelon, the arrangement being well displayed by the pattern of the outcrop of Todilto gypsum, which is repeated and forms two distinct white ridges. The maximum stratigraphic displacement is at least 2,500 feet, shown in secs. 13 and 14, T. 20 N., R. 1 W., where the Todilto and overlying Morrison are in contact with the pre-Cambrian granite. (See pl. 4, B.)

Some features of the Sierra Nacimiento overthrust are well shown in sec. 36, T. 20 N., R. 1 W., and sec. 1, T. 19 N., R. 1 W. Here the main fault passes northward through the central part of these sections. West of it the Senorito sandstone, which had been thrust westward over the upper Chinle (?) shales by a previous fault, dips east at an angle of $25^{\circ}$ to $45^{\circ}$ until it meets the main fault. Here the upper Chinle (?) shales have apparently again acted as a lubrieant. Southward from this place the amount of displacement of the Sierra Nacimiento overthrust varies considerably. In the northeast corner of the Ojo del Espiritu Santo grant the Magdalena group lies against the granite, its strata dipping to the west at a high angle but apparently with little displacement. To the south suc- 
cessively younger beds come in contact with the granite, and near the head of Arroyo Olguin the Chinle (?) formation abuts against the granite. Again near the head of Rito Semilla the Magdalena group is in contact with the granite, and northeast of Los Bancos the Chinle (?) formation abuts against the granite.

In the western part of the Jemez Indian Reservation the strueture is complicated by the cross faults north of the Sierrita Mesa, and the displacement along the major overthrust is in general less than it is to the north, the major overthrust finally dying out near the northwest corner of the Mesa Blanca, along the east limb of the Tierra Amarilla anticline. (See pl. 8, B.)

Sierrita fault.-The fault here designated the Sierrita fault begins near the northwest end of La Ceja and trends about N. $35^{\circ} \mathrm{E}$. toward the southeast end of the Mesa Blanca, thence northward, crossing the Rio Salado and intersecting the southeast end of Sierrita Mesa about 1 mile west of San Ysidro. This fault gives rise to the escarpment which forms the east side of La Sierrita. A mile or less north of the latitude of San Ysidro this fault curves toward the northwest, and near the north line of the Jemez Indian Reservation it splits, the main fault continuing northward along the east side of the Sierra Nacimiento and the other fault extending about $\mathrm{N} .45^{\circ} \mathrm{W}$., almost to the Sierra Nacimiento overthrust. In the northeastern part of the Jemez Indian Reservation, east of the Sierrita fault, there is a minor fault of less displacement with the same general trend as the Sierrita fault. The plateau between the Sierrita fault and the Nacimiento overthrust is thus a horst.

The Sierrita fault is believed to be an overthrust, but the dip of the fault plane is apparently steeper than along the Sierra Nacimiento overthrust. At the surface this fault displaces all beds from the Santa $\mathrm{Fe}$ formation at the south to the pre-Cambrian at the north. At several places along this fault plane the displacement is as much as 2,000 feet.

Jemez fault.-The Jemez fault is east of the Sierrita fault but west of Jemez Creek, which it parallels for a considerable distance. It was traced from the northeast corner of sec. 1, T. 14 N., R. 1 E., as far north as the latitude of Canones, and it doubtless extends considerably farther. Its trend is almost due north to a point about $11 / 2$ miles northwest of San Ysidro, and thence a little east of north. Like the Sierrita fault it has the downthrow on the east and like the other north-south faults at the south end of the Sierra Nacimiento it increases in displacement toward the north. The Santa Fe formation is at the surface on the east side of the fault. At the south the Wasateh formation is first brought against the Santa $\mathrm{Fe}$, then toward the north successively older formations, until northwest of Jemez, in the Jemez Pueblo grant, the pre-Cambrian rock 
rests against the Santa Fe formation, thus indicating a stratigraphic displacement of at least 8,000 feet. This is the maximum displacement found in the eastern part of Sandoval County. The plane of the fault seems to be approximately vertical, but it has resulted from the upthrust of the rocks on the west.

Canada de las Milpas fault.-Between the south end of the Tierra Amarilla and the Canada de las Milpas anticline there is a fault which extends southward for about 5 miles, until its continuity is lost in the Wasatch beds. The downthrow is on the east, as in the Sierrita and Jemez faults, and the maximum displacement is at least 750 feet.

IFaults east of Canones.-East of Jemez Creek near Upper Canones and extending southward for about $4 \frac{1}{2}$ miles there is a series of faults, three of which are shown on Plate 1. Their general trend is N. $20^{\circ}$ to $25^{\circ} \mathrm{W}$. The two eastern faults displace the Permian and basal Triassic strata, and the westernmost one involves the Santa Fe formation. At the north end of the faulted area a mass of rhyolite and rhyolite tuff rests horizontally on the Poleo sandstone, showing that the rhyolite was not involved in the deformation. South of the latitude of Canones the valley of Jemez Creek is in a well-defined graben, with the Santa Fe formation at the surface.

Faults at the north end of La Sierrita.-Crossing the north end of La Sierrita is a fault with a mean trend of about N. $50^{\circ} \mathrm{E}$., which extends from the Sierra Nacimiento overthrust on the west to the Sierrita fault on the east. The downthrow is on the north, and the maximum displacement is at least 200 feet.

North of this fault there are two smaller faults with the same trend, which intersect the Sierra Nacimiento overthrust but do not extend to the Sierrita fault. The southern one is similar to the fault just described, but the northern one has its downthrow on the south.

\section{FOLDS}

La Ventana anticline.-Southwest of La Ventana the basal sand. stones of the Mesaverde formation strike about N. $45^{\circ}$ E. and dip about $5^{\circ} \mathrm{NW}$.; east of La Ventana in the eastern part of sec. 33, T. 19 N., R. 1 W., the same beds strike N. $40^{\circ} \mathrm{W}$. and dip about $6^{\circ} \mathrm{NE}$. The north end of the anticline thus indicated, which is here called the La Ventana anticline, is apparently near the NW. 1/4 sec. 29, T. 19 N., R. $1 \mathrm{~W}$. There is no observable closure at the south end. A well drilled for oil in this anticline during the winter of 1925-26 was abandoned at a depth of 2,003 feet. A log of this well is given on page 39 .

Olguin anticline.-In the Ojo del Espiritu Santo grant about 6. miles southeast of La Ventana and about 1 mile north of Arroya.

3616-31-6 
Olguin there is an anticline about 1 mile long and half a mile wide, indicated by sandy beds in the Mancos shale. It is here called the Olguin anticline. On the east side the prevailing strike is about N. $30^{\circ} \mathrm{W}$. and the dip is about $10^{\circ} \mathrm{E}$., though in one place it is as much as $25^{\circ} \mathrm{E}$. On the west side the strike ranges from northeast to northwest, and the average dip is about $9^{\circ} \mathrm{W}$. Apparently the anticline is closed at the north end, but if there is closure at the south end it is concealed by a covering of alluvium and soil.

Cabezon anticline.-About 4 miles southeast of the village of Cabezon the Albuquerque road passes over the Cabezon anticline, the axis of which trends about $\mathrm{N}$. $70^{\circ} \mathrm{W}$. Its relations are indicated by the outcrop of a thin-bedded sandstone in the Mancos shale. The mean dip of the northeast limb is about $2^{\circ} 30^{\prime} \mathrm{N}$.; the dip of the southwest limb is $3^{\circ}$ to $6^{\circ} \mathrm{SW}$. No closure was found at the southeast end; at the nose-shaped northwest end the dip is about $1^{\circ} 30^{\prime}$. This anticline is about $11 / 2$ miles long and half a mile wide.

Guadalupe anticline.-South of Cerro Chato on the east side of the Rio Puerco, in the west face of the Mesa Prieta, the heavy sandstone beds in the Mancos shale dip $3^{\circ}$ to $4^{\circ} \mathrm{E}$. and strike N. $20^{\circ}$ E. to N. $30^{\circ} \mathrm{W}$. On the west side of the Rio Puerco the Mancos shale dips $4^{\circ}$ to $6^{\circ} \mathrm{W}$. and strikes N. $40^{\circ}$ E. to N. $25^{\circ} \mathrm{W}$. The anticline indicated by these dips closes at the north near the village of Guadalupe, but it is not known to have closure at the south. It is here called the Guadalupe anticline.

Rio Salado anticline.-Just west of the Jemez Indian Reservation is an imperfect anticline, indicated by the Todilto outcrop, which swings around the north, west, and south sides with a dip of $5^{\circ}$ to $10^{\circ}$. (See pl. 8, A.) The east side of the anticline is on the downthrown side of the Sierra Nacimiento overthrust, and the beds adjacent to this fault have been dragged upward along the fault plane so that they dip steeply westward at angles of $20^{\circ}$ to $75^{\circ}$ at the outcrop but flatten very noticeably toward the west. The Chinle (?) formation is at the surface in the center of this anticline. Two wells drilled on this anticline in an unsuccessful search for oil, the Kaseman wells 1 and 2, are described on pages 82-83.

Tierra Amarilla anticline.-East and northeast of the Canada de las Milpas anticline and in the same general area is the welldefined Tierra Amarilla anticline, which is about 6 miles long and 1 mile wide. It lies mostly in secs. $5,8,9,16$, and $17, T .15 \mathrm{~N}$., R. 1 E., but its northern continuation extends into the San Ysidro grant and the southwest corner of the Jemez Indian Reservation. It is indicated by the curved outcrop of the Todilto formation, which almost completely encircles it. The beds dip $40^{\circ}$ to $80^{\circ}$ on the east and west limbs. North of the Rio Salado the general trend of this anticline is approximately north, but south of the river the trend is 
about N. $25^{\circ}$ W. The Sierra Nacimiento overthrust, which here is apparently a normal fault downthrown to the west, borders this anticline on the northeast; but the fault dies out about 1 mile south of the Rio Salado.

On the south side of the Rio Salado the apex of the Tierra Amarilla anticline is covered with travertine and thermal-spring deposits. (See p. 87 and pl. 8, B.) These deposits are more than a mile in length, are about half a mile wide, and at several places. attain a thickness of 100 to 150 feet.

Canada de las Milpas anticline.-Southwest of the Tierra Amarilla anticline and west of the arroyo known as Canada de las Milpas is the Canada de las Milpas anticline, a closed fold, the crest of which is mostly in the W. $1 / 2$ sec. 20, T. 15 N., R. 1 W. There the Todilto formation is at the surface and is flanked by the Morrison formation. This anticline trends about N. $20 \mathrm{~W}$., and its maximum length is about 2 miles. The dips along its axis are $40^{\circ}$ to $45^{\circ}$ east and west.

\section{AGE OF DEFORMATION}

The Santa Fe formation, regarded as of Miocene and Pliocene age, is involved in the deformation of the Sierra Nacimiento and San Pedro Mountain, a feature clearly visible at many places along the Sierrita fault. The late Tertiary basalt and rhyolite were apparently not involved in the major deformation, as shown by the fact that along one of the faults east of Jemez Creek and southeast of Lower Canones there is a small area of flat-lying rhyolite tuff resting on deformed Permian beds. (See p. 75.)

\section{QUALITY OF GROUND WATER}

\section{SOURCE OF INFORMATION}

For the purpose of ascertaining the quality of water in western Sandoval County samples were collected and sent to the waterresources laboratory of the United States Geological Survey for chemical analysis. Information was obtained also by tasting the water and from statements of the inhabitants of the area as to its utility. The data obtained relate chiefly to the water in the Cretaceous, Tertiary, and Quaternary rocks; little information was obtained about water in the Triassic and Permian beds, in which no wells had been sunk at the time the investigation was made.

\section{QUANTITY AND CHARACTER OF DISSOLVED SOLIDS}

The ground waters of western Sandoval County contain as their principal dissolved constituents the basic radicles calcium $(\mathrm{Ca})$, magnesium $(\mathrm{Mg})$, sodium $(\mathrm{Na})$, and potassium $(\mathrm{K})$, and the acid radicles bicarbonate $\left(\mathrm{HCO}_{3}\right)$, sulphate $\left(\mathrm{SO}_{4}\right)$, and chloride $(\mathrm{Cl})$. 
The water analyses are tabulated below, and some of them are represented graphically by reacting values or milligram equivalents ${ }^{85}$ in Plate 9, the method of representation being adapted from that suggested by Collins. ${ }^{88}$

Analyses of waters from western Sandoval County, N. Mex.

Analyses by H. B. Riffenburg (Nos. 3-15, 17-22), C. S. Howard (Nos. 1 and 2), and Margaret D. Foster (No. 16). Parts per million]

\begin{tabular}{|c|c|c|c|c|c|c|c|c|c|c|c|}
\hline No. & $\begin{array}{l}\text { Total } \\
\text { dis- } \\
\text { solved } \\
\text { solids }\end{array}$ & $\begin{array}{c}\text { Silica } \\
\left(\mathrm{SiO}_{2}\right)\end{array}$ & $\begin{array}{l}\text { Iron } \\
(\mathrm{Fe})\end{array}$ & $\begin{array}{l}\text { Cal- } \\
\text { cium } \\
\text { (Ca) }\end{array}$ & 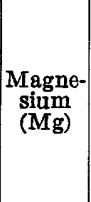 & $\begin{array}{c}\text { Sodium } \\
\text { and } \\
\text { potas- } \\
\text { sium } \\
(\mathrm{Na}+\mathrm{K})\end{array}$ & $\begin{array}{l}\text { Bicar- } \\
\text { bonate } \\
\text { radicle } \\
\left(\mathrm{HCO}_{3}\right)\end{array}$ & $\begin{array}{c}\text { Sul- } \\
\text { phate } \\
\text { radicle } \\
\left(\mathrm{SO}_{4}\right)\end{array}$ & $\begin{array}{l}\text { Chlo- } \\
\text { ride } \\
\text { radicle } \\
\text { (Cl) }\end{array}$ & $\begin{array}{c}\text { Nitrate } \\
\text { radicle } \\
\left(\mathrm{NO}_{3}\right)\end{array}$ & $\begin{array}{l}\text { Total } \\
\text { hardness } \\
\text { as CaCO } \\
\text { (calcu- } \\
\text { lated } \\
\text { from eal- } \\
\text { cium and } \\
\text { magne- } \\
\text { sium), }\end{array}$ \\
\hline 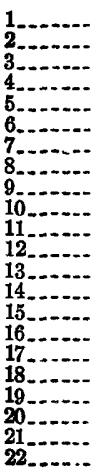 & \begin{tabular}{|r}
229 \\
79 \\
2,708 \\
872 \\
396 \\
693 \\
628 \\
700 \\
933 \\
782 \\
7,320 \\
610,960 \\
7,510 \\
11,040 \\
466 \\
11,120 \\
67,887 \\
$\cdot 4,344$ \\
140 \\
$d 2,562$ \\
$-2,184$ \\
$f 3,458$
\end{tabular} & $\begin{array}{l}5.8 \\
22 \\
16 \\
16 \\
30 \\
48 \\
56 \\
59 \\
41 \\
67 \\
15 \\
15 \\
30 \\
25 \\
49 \\
18 \\
324 \\
146 \\
70 \\
259 \\
91 \\
48\end{array}$ & $\begin{array}{r}.12 \\
.58 \\
.20 \\
\text { Trace. } \\
.30 \\
1.2 \\
.20 \\
.13 \\
.48 \\
.40 \\
3.0 \\
2.0 \\
.60 \\
.75 \\
.17 \\
2.3 \\
1,250 \\
72 \\
.40 \\
252 \\
1.2 \\
.10\end{array}$ & $\begin{array}{c}52 \\
6.8 \\
360 \\
149 \\
90 \\
58 \\
73 \\
40 \\
91 \\
85 \\
368 \\
494 \\
260 \\
480 \\
63 \\
400 \\
303 \\
316 \\
12 \\
41 \\
166 \\
328\end{array}$ & $\begin{array}{c}13 \\
2.4 \\
94 \\
28 \\
12 \\
15 \\
20 \\
15 \\
17 \\
15 \\
85 \\
91 \\
70 \\
96 \\
9.0 \\
73 \\
33 \\
51 \\
2.4 \\
16 \\
9.0 \\
23\end{array}$ & $\begin{array}{c}13 \\
3.0 \\
324 \\
106 \\
29 \\
180 \\
115 \\
187 \\
198 \\
160 \\
2,219 \\
3,310 \\
2,400 \\
3,130 \\
91 \\
3,450 \\
157 \\
127 \\
14 \\
52 \\
645 \\
1,000\end{array}$ & $\begin{array}{r}209 \\
29 \\
371 \\
427 \\
259 \\
478 \\
310 \\
403 \\
210 \\
500 \\
1,757 \\
1,969 \\
1,301 \\
386 \\
290 \\
1,498 \\
0 \\
0 \\
71 \\
0 \\
791 \\
1,440\end{array}$ & $\begin{array}{c}33 \\
6.2 \\
1,584 \\
336 \\
99 \\
41 \\
42 \\
80 \\
277 \\
162 \\
1,712 \\
3,401 \\
1,728 \\
4,543 \\
16 \\
3,645 \\
6,156 \\
3,159 \\
4.9 \\
2,337 \\
42 \\
40\end{array}$ & $\begin{array}{c}1.9 \\
1.0 \\
24 \\
6.0 \\
4.0 \\
106 \\
100 \\
96 \\
154 \\
12 \\
1,940 \\
2,500 \\
2,330 \\
2,370 \\
94 \\
2,660 \\
54 \\
1.0 \\
1.0 \\
20 \\
820 \\
1,320\end{array}$ & $\begin{array}{c}\text { Trace. } \\
\text { Trace. } \\
\text { Trace. } \\
\text { Trace. } \\
.25 \\
6.0 \\
80 \\
18 \\
30 \\
\text { Trace. } \\
\text { Trace. } \\
\text { Trace. } \\
\text { Trace. } \\
\text { Trace. } \\
\text {.50 } \\
\text { Trace. } \\
\text { Trace. } \\
\text { Trace. } \\
0 \\
5.0 \\
\text { Trace. }\end{array}$ & $\begin{array}{r}183 \\
27 \\
1,285 \\
487 \\
274 \\
206 \\
264 \\
162 \\
297 \\
274 \\
1,268 \\
1,608 \\
937 \\
1,594 \\
194 \\
1,299 \\
244 \\
424 \\
40 \\
168 \\
452 \\
914\end{array}$ \\
\hline
\end{tabular}

- Borate $\left(\mathrm{BO}_{3}\right) 50$ parts per million.

- Acidity as $\mathrm{SO}_{4} 5,400$ parts per million, aluminum 303 , phosphate $\left(\mathrm{PO}_{4}\right) 37$.

- Acidity as $\mathrm{SO}_{4} 2,328$ parts per million, aluminum 421, hydrogen sulphide $\left(\mathrm{H}_{2} \mathrm{~S}\right) 2.1$, phosphate $\left(\mathrm{PO}_{4}\right) 41$.

- Acidity as $\mathrm{SO}_{4} 2,256$ parts per million, aluminum 90, hydrogen sulphide $\left(\mathrm{H}_{2} \mathrm{~S}\right)$ 1.6, phosphate $\left(\mathrm{PO}_{4}\right){ }^{154}$.

Borate $\left(\mathrm{BO}_{3}\right) 2.5$ parts per million.

$i$ Borate $\left(\mathrm{BO}_{3}\right) 2.5$ parts per million.

1. Spring in NE. $1 / 4$ NW. $1 / 4$ sec. 26 , T. 19 N., R. 2 W., owned by O. K. Ash. Water from sandstone in Mesaverde formation. Temperature $58^{\circ} \mathrm{F}$. Collected October 2, 1925.

2. Dug well, 7 feet deep, 4 feet in diameter, in NE. 1/4 sec. 31, T. 20 N., R. 2 W., owned by George E. Conlisk. Water from sandstone in the Puerco formation. Temperature $54^{\circ}$ F. Collected September 29, 1925.

80 The milligram equivalent is obtained from the following formula :

$$
\begin{aligned}
& \text { Combining weight of radicle }=\frac{\text { atomic weight or sum of atomic weights }}{\text { valence of radicle }} \\
& \text { Number of milligram equivalents }=\frac{\text { parts per million }}{\text { combining weight of radicle }}
\end{aligned}
$$

In the diagrams 1 milligram equivalent equals 23 parts per million $\mathrm{Na}, 39 \mathrm{~K}, 20 \mathrm{Ca}$. $12 \mathrm{Mg}, 61 \mathrm{HCO}_{3}, 30 \mathrm{CO}_{3}, 48 \mathrm{SO}_{4}, 35.4 \mathrm{Cl}$.

Geochemical methods of interpretation of water analyses are discussed in the following: papers: Palmer, Chase, The geochemical interpretation of water analyses: U. S. Geol. Survey Bull. 479, 1911; Rogers, $G_{n}$ S., The interpretation of water analyses by the geologist : Econ. Geology, vol. 12, pp. 56-88, 1917.

Collins, W. D., Graphic representation of water analyses: Ind. and Eng. Chemistry. vol. 15 , p. 394,1928 . 
3. Dug well, 22 feet deep, $4 \frac{1}{2}$ feet in diameter, in Cuba, owned by J. F. Young. Water from alluvium. Temperature 52 $2^{\circ}$. Collected September 5, 1924.

4. Drilled well, 150 feet deep, 6 inches in diameter, in Cuba, owned by A. Eichwald. Water from alluvium and from the Puerco formation. Water level 110 feet below surface. Temperature 52 ${ }^{\circ}$ F. Collected September 5, 1924.

5. Spring at Ojo del Espiritu Santo ranch house, owned by $\mathrm{Mr}$. Catron. Water comes from alluvium but probably is contributed by the Dakota (?) sandstone. Temperature $60^{\circ}$ F. Collected September 22, 1924.

6. Dug well, 13 feet deep, 31/2 feet in diameter, at San Ysidro, owned by J. W. Miller. Water from alluvium. Depth of water in well is 2 feet 4 inches. Collected September 27, 1924.

7. Drilled well, 100 feet deep, 6 inches in diameter, on main road at south end of Jemez, owned by the pueblo. Water level 38 feet below surface. Collected September 25, 1924.

8. Drilled well, about 125 feet deep, 6 inches in diameter, on east side of Jemez, owned by the pueblo. Collected September 25, 1924.

9. Drilled well, 30 feet deep, 6 inches in diameter, about 200 jards south of Santa Ana, owned by the pueblo. Water probably from the Santa Fe formation. Collected September 27, 1924.

10. Dug well, 16 feet deep, 14 feet in diameter, at Bernalillo, owned by White Pine Lumber Co. Water from alluvial gravel. Collected September 29, 1924.

11. Spring, one of the San Ysidro group, north of Rilo Salado, along road 2.7 miles west of San Ysidro. Deposit of calcareous tufa around spring. Temperature $68^{\circ} \mathrm{F}$. Collected September 15, 1924.

12. Spring, one of the San Ysidro group, on hill south of Rio Salado, about 3 miles west-southwest of San Ysidro. Water comes to surface near the contact between the Wingate sandstone and the Chinle (?) formation. Deposit of calcareous tufa around springs. Temperature $86^{\circ}$ F. Collected September 15, 1924.

13. Swimming Pool Spring, at north edge of Sierrita Mesa. Temperature $70^{\circ} \mathrm{F}$. Collected September 14, 1924.

14. Rio Salado, 4 miles west of San Ysidro. Water slightly turbid; rain about 5 days before sample was collected. Collected September 15, 1924.

15. Jemez Creek near Jemez. Water slightly turbid, but no rain in 10 days preceding. Collected September 25, 1924.

16. Kaseman well No. 1. Drilled well in Ojo del Espiritu Santo grant. Depth 550 feet, diameter 12 inches. Estimated yield 2,450 gallons a minute. Temperature $115^{\circ}$ F. September 29, 1926.

17. Springs at men's bathhouse, Sulphur Springs. Temperature $110^{\circ} \mathrm{F}$. Collected August 31, 1924.

18. Alum Spring, 100 yards north of hotel at Sulphur Springs. Temperature $76^{\circ}$ F. Collected August 31, 1924.

19. Turkey Spring, five-eighths of a mile northeast of hotel at Sulphur Springs. Water issues from the base of a vegetation-covered slope of porphyritic andesite. Collected September 1, 1924.

20. Foot Bath Spring, Sulphur Springs. Temperature $99^{\circ}$ F. Collected August 31, 1924.

21. Spring at bathhouse, Jemez Hot Springs. Temperature $125^{\circ}$ F. Collected August 21, 1924.

22. Spring at Soda Dam, 11/4 miles north of Jemez Springs. Temperature $104^{\circ}$ F. Collected August 21, 1924. 
There is a considerable variation in the chemical character of the ground water in this area. The best water analyzed (No. 2) was found in G. E. Conlisk's well, in the NE. 1/4 sec. 31, T. 20 N., R. 2 W. This water contains only 79 parts per million of total dissolved solids and is soft. The water from the well of J. F. Young, at Cuba (No. 3), contains 2,708 parts per million of total dissolved solids and has a calculated hardness of 1,285 parts per million. Other waters are still more highly mineralized. The average amount of total dissolved solids of the waters shown in Plate 9 is 800 parts per million.

Inspection of analyses 1 to 10 shows that bicarbonate and sulphate are the principal acid radicles except in the waters collected from wells along Jemez Creek (Nos. 6, 7, 8, and 9), which contain considerable amounts of chloride. This chloride is probably derived from the Permian and Triassic formations over which Jemez Creek flows.

The waters from the San Ysidro Springs, Nos. 11 and 12, described on pages $86-87$, are highly mineralized and are probably of different origin from most of the other springs of the area. No. 11 contains 7,320 parts per million and has a temperature of $68^{\circ} \mathrm{F}$; N No. 12 contains 10,960 parts per million and has a temperature of $86^{\circ} \mathrm{F}$. These waters contain large amounts of chloride, sulphate, and bicarbonate.

\section{RELATION OF QUALITY TO USE}

Calcium and magnesium in a water produce hardness, and a water with any considerable amount of these constituents is unsatisfactory for laundry use without first softening or "breaking" it. Salts of calcium and magnesium also form scale when the water is used in a steam boiler.

A water which has little or no calcium or magnesium is designater a soft water. Some soft waters carry considerable quantities of salts of sodium, especially sodium bicarbonate or sodium sulphate. Water of this type is desirable for laundry and domestic use but is not suitable for irrigation because the sodium bicarbonate forms black alkali $\left(\mathrm{Na}_{2} \mathrm{CO}_{3}\right)$, which is generally recognized as exceedingly harm. ful to the soil.

Of the waters shown in Plate 9 all are hard except No. 2, but all are potable, though No. 3 has a taste which is objectionable to many people. The rather unpleasant taste is due in large part to the presence of magnesium sulphate, which is decidedly bitter.

On the whole, the waters shown in Plate 9, which are the more normal ground waters of this area, are superior in quality to the waters in many of the semiarid regions of the western United States.

\section{CHANGES IN CHEMICAL CHARACTER OF WATER WITH DEPTH}

Shallow ground water is rather generally hard, but in many places where such hard water exists it has been shown that the water en- 
countered at greater depth is soft. This variation in chemical character of water with increase in depth has been explained as follows: ${ }^{87}$

The ground water as it percolates to greater depth reacts with certain silicate minerals in the rocks, the calcium and magnesium combining with the silicate minerals, which in return contribute sodium to the water; the calcium and magnesium are thus exchanged for sodium, hence the name base-exchange silicate is applied to minerals that possess this property. The most effective of these minerals are those of the bentonite group ${ }^{88}$ but feldspar, mica, and other silicates also possess this property. ${ }^{89}$

All the waters illustrated in Plate 9 came from relatively shallow depths and are hard. However, the Tertiary rocks and some of the Cretaceous rocks in this region very probably possess the property of base exchange, and it is probable that waters obtained at a depth of several hundred feet in the Nacimiento group, Wasatch formation, Mesaverde formation, Dakota (?) sandstone, and perhaps also the Morrison formation will be soft. It is not unlikely that some of this deep-lying water will be a soft sodium bicarbonate and sodium sulphate water, of a type which is generally unsatisfactory for irrigation unless the soil is treated to prevent the formation of black alkali. Therefore, before any large-scale irrigation project with wells is undertaken in this area the quality of the water should be determined. In this connection it should be remembered that powdered gypsum put on the land will prevent the formation of black alkali from a sodium bicarbonate water. Gypsum is abundant in this region, the Todilto formation heing composed almost entirely of it.

\section{ARTESIAN CONDITIONS}

\section{GENERAT PRINCIPLES}

In this area there are several localities that give promise of developing artesian flow; in fact, since the field investigation was completed flowing wells have been obtained in at least one locality. (See pp. 82-83.)

The general principles underlying artesian flow were understood at least as far back as the first part of the last century and are described in many textbooks and in reports of the Geological Survey,

87 Thresh, J. C., The alkaline waters of the London Basin: Chem. News (London), pp. 40, 43, 1912. Renick, B. C., Base exchange in ground water by silicates as illustrated in Montana : U. S. Geol. Survey Water-Supply Paper 520, pp. 53-72, 1925; Geology and ground-water resources of central and southern Rosebud County, Mont.: U. S. Geol. Survey Water-Supply Paper 600, pp. 41-42, 1929.

${ }^{8}$ Ross, C. S., and Shannon, E. V., The minerals of bentonite and related clays and their physical properties: Am. Ceramic Soc. Jour., vol. 9, pp. 77-96, 1926.

${ }^{8}$ Sullivan, E. C., The interaction between minerals and water solutions, with special reference to geologic phenomena : U. S. Geol. Survey Bull. 312, 1907. 
among which may be mentioned those of Chamberlin, ${ }^{90}$ Norton, ${ }^{91}$ and Fuller. ${ }^{92}$ In order to obtain an artesian flow it is necessary to have a permeable water-bearing bed, such as sandstone or limestone, overlain by an impervious bed, such as shale, and the waterbearing bed must have an inclination such that its intake area is at a higher altitude than the well. The head of the water in the well will depend upon the distance from the intake area to the well, the difference in altitude, and the permeability of the water-bearing bed; the hydraulic gradient, or space rate of decline in the head, is determined by the frictional resistance to the flow of the water through the water-bearing bed.

\section{AREAS OF ARTESIAN FLOW}

PROVED AREAS

Arroyo Cachana Valley.-The tract along the Arroyo Cachana and its headwater tributaries, from a place about 1 mile south of Los Bancos southward to the north end of the Sierrita Mesa, is a good locality for prospecting for artesian flows. This tract is within the Ojo del Espiritu Santo grant. The Poleo sandstone, which is water bearing, forms the ridge to the east. Where it appears at the surface it dips about $75^{\circ} \mathrm{W}$. The dip, however, diminishes rapidly toward the west, and within less than a mile it is not more than $10^{\circ}$.

Two wells drilled on the Rio Salado anticline in this locality to test the petroleum possibilities were visited by the writer in October, 1926. One of these wells, the Kaseman No. 1, encountered heavy flows of hot, salty artesian water at a depth of 500 feet. This water comes from the Poleo sandstone which crops out less than a mile to the east. When the writer visited this well, about 6 months after it was drilled, there was 12 inches of water flowing over a 10-inch casing at an estimated rate of 2,450 gallons a minute. It is claimed that the initial pressure in this well was 225 pounds to the square inch. The well was abandoned at 550 feet after an unsuccessful attempt had been made to shut off the water. An analysis of the water is given as No. 16, page 78.

The other well, the Kaseman No. 2, about a mile farther north, was drilled to a depth of 2,008 feet. The first flow was obtained at 425 feet, and below that depth a number of other flows were encountered. When visited by the writer in October, 1926, this well had reached a depth of about 1,800 feet and drilling was still in prog.

${ }^{0}$ Chamberlin, T. C., Requisite and qualifying conditions of artesian wells: U. S. Geol. Survey Fifth Ann. Rept., pp. 131-173, 1883-1884.

${ }^{01}$ Norton, W. H., Artesian wells of Iowa : Iowa Geol. Survey, vol. 6, pp. 122-128, 1897.

92 Fuller, M. L., Summary of the controlling factors of artesian flows: U. S. Geol. Survey Bull. 319, 1908. 


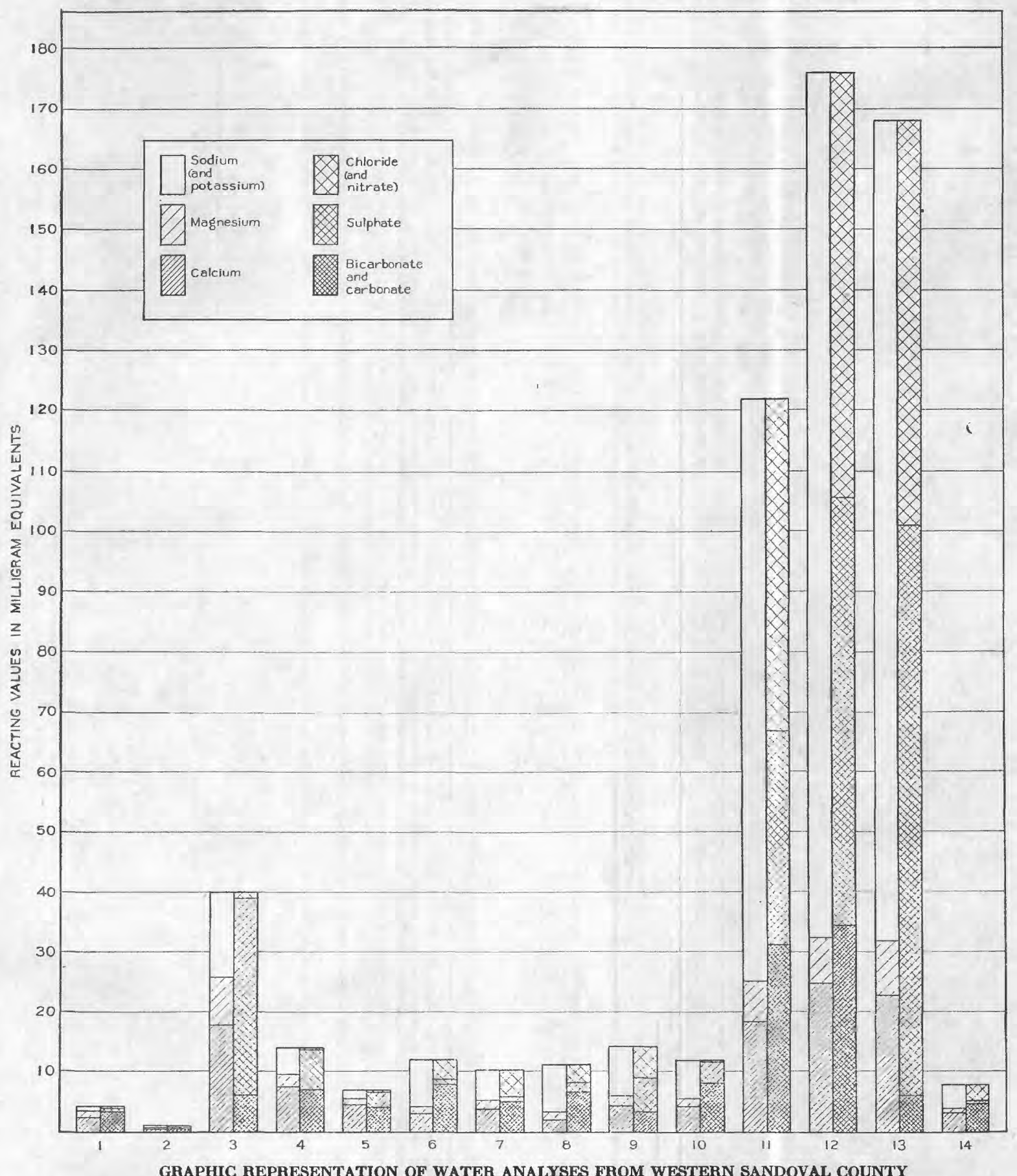

GRAPHIC REPRESENTATION OF WATER ANALYSES FROM WESTERN SANDOVAL COUNTY

The numbers of the analyses correspond with those used in the table on page 78. 
ress. With three strings of casing in the hole, shutting off much water, Mr. F. H. Healy, of the State engineer's office, estimated that the water coming to the surface around the several casings amounted'. to 2,050 gallons a minute.

\section{Log of Kaseman well No. 2, Ojo del Espiritu Santo ranch}

[Driller's log. Formation names indicate probable correlation. Well drilled with cable tools; 12-inch casing to 486 feet, 8 -inch casing to 940 feet, 6 -inch casing to 1,810 feet]

\begin{tabular}{|c|c|c|c|c|c|}
\hline & $\begin{array}{c}\text { Thick- } \\
\text { ness } \\
\text { (feet) }\end{array}$ & $\begin{array}{l}\text { Depth } \\
\text { (feet) }\end{array}$ & & $\begin{array}{c}\text { Thick- } \\
\text { ness } \\
\text { (feet) }\end{array}$ & $\begin{array}{l}\text { Depth } \\
\text { (feet) }\end{array}$ \\
\hline 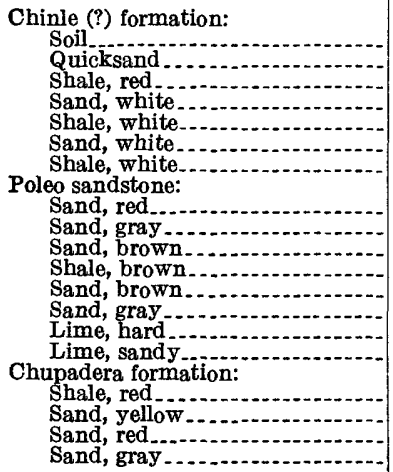 & $\begin{array}{r}15 \\
5 \\
398 \\
57 \\
15 \\
75 \\
35 \\
\\
45 \\
20 \\
10 \\
15 \\
10 \\
15 \\
15 \\
70\end{array}$ & $\begin{array}{r}15 \\
20 \\
418 \\
475 \\
490 \\
565 \\
600 \\
\\
645 \\
665 \\
675 \\
690 \\
700 \\
715 \\
730 \\
800\end{array}$ & 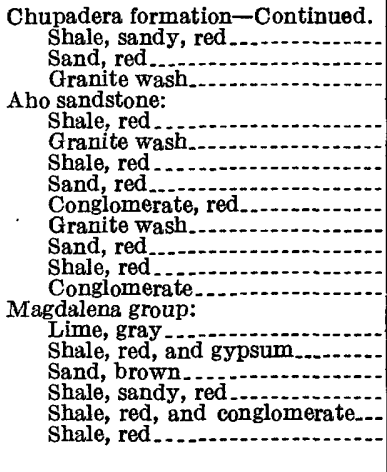 & $\begin{array}{r}10 \\
65 \\
40 \\
10 \\
105 \\
5 \\
20 \\
90 \\
10 \\
10 \\
10 \\
25 \\
25 \\
40 \\
20 \\
8\end{array}$ & $\begin{array}{l}1,500 \\
1,515 \\
1,525 \\
1,535 \\
1,600 \\
1,640 \\
1,650 \\
1,755 \\
1,760 \\
1,780 \\
1,870 \\
1,880 \\
1,890 \\
1,915 \\
1,940 \\
1,980 \\
2,000 \\
2,008\end{array}$ \\
\hline
\end{tabular}

The following data recorded by Mr. Houston, the driller, show that the water from successive beds increased in temperature with the depth.

Temperature of water in the Kaseman well No. 2

\begin{tabular}{|c|c|c|c|}
\hline Depth (feet) & Temperature $\left({ }^{\circ} \mathrm{F}.\right)$ & Depth (feet) & Temperature $\left({ }^{\circ} \mathrm{F}.\right)$ \\
\hline $425 \ldots$ & 108 & $1,060 \ldots$ & \\
\hline 490 & 108 & 1,570 & -125 \\
\hline 550 & 112 & 1,760 & $-\ldots 142$ \\
\hline 610 & 116 & 1,920 & ---n- \\
\hline 910 & 124 & & \\
\hline
\end{tabular}

Water collected from several depths was sent to the New Mexico College of Agriculture and Mechanic Arts for analysis. The results. are given below.

Partial analyses of water from Kaseman vell No. 2

[Parts per million. C. W. Botkin, analyst]

\begin{tabular}{|c|c|c|c|}
\hline & 1 & 2 & 3 \\
\hline $\begin{array}{l}\text { Total mineral matter } \\
\text { Sodium chloride }(\mathrm{NaCl}) \\
\text { Carbonate (as } \mathrm{CaCO} \text { ) }\end{array}$ & $\begin{array}{r}11,760 \\
5,450 \\
1,130\end{array}$ & $\begin{array}{l}7,780 \\
3,800 \\
1,510\end{array}$ & $\begin{array}{l}\mathbf{5}, 580 \\
2,890 \\
1,710\end{array}$ \\
\hline
\end{tabular}

Remainder largely sulphates of calcium, magnesium, and sodium.

1. Water above 940 feet; between the 12 and 8 inch casings.

2. Water between 940 and 1,810 feet; between the 8 and 6 inch casings.

3 . Water between 1,810 and 1,800 feet; below the 6 -inch casing Oct. 2,1926 . 
San Jose-Puerco Valley.-Underlying the San Jose-Puerco Valley there are several beds that may supply artesian water, and in some parts of the valley certain of these beds may be reached at relatively shallow depths. The valley of the San Jose, from a point about $2 \frac{1}{2}$ miles north of Cuba up almost to the headwaters, may be regarded as a prospective artesian basin. A well drilled near the La Jara store will probably afford a good test of this part of the valley; it will not be necessary to drill very deep, because the basal sandstone of the Wasatch formation is only a short distance below the surface, and beneath it are the sandstones of the Nacimiento group, which should prove to be water bearing. These sandstones crop out on the flanks of the mountain 500 feet or more above the valley, so there should be ample head for an artesian flow. The depth necessary for drilling in order to reach the basal sandstone of the Wasatch and the sands of the Nacimiento group increases progressively upstream from La Jara store. From La Jara downstream toward Cuba the difference in altitude between the highest outcrop of the Nacimiento group and the valley bottom decreases; therefore, in the vicinity of Cuba the chances of obtaining artesian flows from the Nacimiento group are not so good. (See pp. 94-95.)

At Cuba there is some possibility of obtaining an artesian flow from the Mesaverde formation, but it is not certain that a flow could be obtained, and in order to reach the Mesaverde it would be necessary to drill through 200 feet or more of basal Puerco and about 1,500 feet of Lewis shale.

The valley of the Rio Puerco in the vicinity of Arroyo de los Pinos is another tract that is favorable for testing the artesian prospects. It is expected that the sandstones in the Mesaverde formation here will prove to be a source of artesian water. A well drilled along the Rio Puerco half a mile or so above the mouth of Arroyo de los Pinos, after passing through the alluvium, would enter the Mesaverde and continue in it for about 800 feet, penetrating most of the best water-bearing sandstones of this formation. The Mesaverde formation extends for several miles upstream, but the depth to the formation increases progressively in that direction.

At La Ventana the Mesaverde is absent, but there is another waterbearing bed below the surface, the Dakota (?) sandstone, which is reached at a depth of about 1,800 feet in the La Ventana well. Southward along the Rio Puerco as far as San Luis the Dakota (?) sandstone probably lies at about the same depth.

If artesian water is obtained from these Cretaceous and Tertiary formations and if it should prove to be a sodium bicarbonate water, 
the formation of black alkali may be prevented by putting powdered gypsum on the land. There is a great abundance of gypsum in this region.

Rio Puerco south of Guadahope.-In the Rio Puerco Valley south of Guadalupe the Dakota (?) sandstone will probably be encountered at depths of 700 to 1,500 feet, or perhaps less. There is some possibility that flows may be obtained from it in the strip west of the Mesa Prieta.

Lower Rio Salado.-Along the flood plain of the Rio Salado, between Sierrita Mesa and Mesa Blanca, flowing wells could probably be obtained, but the water would be highly mineralized. Wells drilled here would encounter the Poleo sandstone, which crops out on the north and has a relatively large intake area, most of which is 800 feet or more above the Rio Salado Valley. Artesian flows are also to be expected from the sandstones underlying the Poleo; the water would probably be slightly thermal, and like that found in the Kaseman wells (pp. 82-83) it would probably be too highly mineralized for domestic or agricultural use.

Upper Rio Salado.- There are prospects of obtaining flowing wells in the strip of country bordering the Rio Salado from a point south of Los Bancos to a point approximately west of the north face of Sierrita Mesa, but unfortunately the water may not be of satisfactory quality, as it will probably come from the Wingate sandstone or from the lower Poleo sandstone. The Poleo will be penetrated at 900 to 1,400 feet, the depth depending upon the location; throughout most of this tract it can be reached at a depth of about 1,000 feet.

Chachulie Arroyo.-The tract of country north of the outcrop of Dakota (?) sandstone, along Chachulie Arroyo, may prove to be underlain by artesian water. If a well fails to find artesian water or a satisfactory supply in the Dakota (?) sandstone, it should be continued into the Morrison formation, which may here prove to be water bearing. Although flowing wells may not be obtained, the water will certainly be under considerable hydrostatic head.

Arroyo Piedra Lumbre.-The tract immediately bordering Arroyo Piedra Lumbre, in secs. 21, 22, 28, 29, 32, and 33, T. 19 N., R. 2 W., and even farther south, may prove to have artesian water. Sandstones of the Mesaverde formation crop out to the east and south and dip beneath this valley. Wells drilled into these sandstones will doubtless yield water and may develop artesian flows.

Arroyo Piedra Parada.-In the valley of Arroyo Piedra Parada, in secs. 22 and 23, T. 15 N., R. 1 E., the Dakota (?) sandstone will be encountered near the surface. This sandstone and the underlying Morrison formation may yield artesian flows. 
Canada de las Milpas.-There is a tract of land in the central part of sec. 20, T. 15 N., R. 1 E., east of the Canada de las Milpas anticline and southwest of the Tierra Amarilla anticline, where the water-bearing character of the Dakota (?) sandstone may be tested with a slight chance that it may yield an artesian flow, but this tract is small and not considered so favorable as those above described. The Dakota (?) sandstone is faulted out in the north-central part of sec. 20.

Other prospective areas.-In addition to the prospective areas described above, there may be others whose structure is concealed by the Santa Fe formation and by surficial deposits, but it is not advisable to make further predictions without information on subsurface conditions.

\section{MINERALIZED SPRINGS AND SPRING DEPOSITS}

Near the south end of the Sierra Nacimiento there are a number of springs, all of which yield highly mineralized water. Some are thermal; others are not. These springs and those at Jemez Springs and Sulphur Springs were studied by Kelly and Anspach. ${ }^{93}$ Their waters are too highly mineralized to be potable and have a rather complex history. The springs occur in three different localities, and in the paper by Kelly and Anspach they are referred to as the Indian Springs, the San Ysidro Springs, and the Phillips Springs. The same names will be used here.

\section{INDIAN SPRINGS}

The Indian Springs are about $1 \frac{1}{2}$ miles north of San Ysidro, in the Jemez Pueblo grant. They occur mostly in an east-west belt. Kelly and Anspach ${ }^{94}$ report that they even extend east of the river, where the temperature of the water is about $120^{\circ}$, but those east of Jemez Creek were not observed by the writer; they may now be covered up by alluvium from the stream. The springs west of Jemez Creek are located in a faulted belt, in which the trend of the observable faults approaches due north. These springs have in places built up small deposits of sinter, but none approaching in magnitude the deposits of the Phillips Springs or the south group of the San Ysidro Springs.

\section{SAN YSIDRO SPRINGS}

There are two groups of springs in the so-called San Ysidro Springs-one north and the other south of the Rio Salado. These two groups are referred to as the north group and the south group.

\footnotetext{
es Kelly, Clyde, and Anspach, E. V., A preliminary study of the waters of the Jemez Plateau: New Mexico Univ. Bull., Chemistry ser., vol. 1, pp. 1-73, 1913.

os Idem, p. 6 .
} 
The springs of the north group, not less than 20 in number, issue along the San Ysidro-Cuba road, mostly in the N. 1/2 sec. 9, S. 1/2 sec. 3, and NW. $1 / 4$ sec. 10, T. 15 N., R. 1 E. Analysis 11 (p. 78) shows the chemical character of the water from one of these springs. The observed temperature did not exceed $68^{\circ} \mathrm{F}$. Many of the springs have built small craters of calcareous tufa 1 to 4 feet high and 3 to 6 feet or more in diameter. The land near the springs is marshy. Gas is being evolved from most of these springs. The water comes to the surface mostly in the area of outcrop of the Chinle (?) formation near the contact with the underlying Poleo sandstone. Although the water is nonpotable for human beings, stock apparently drink it in preference to the water in the Rio Salado. There are certain of these springs which the stock apparently prefer; it is uncertain whether or not there is any considerable variation in the quality of the water in different springs.

The springs of the south group are mostly in the central part of sec. 8, T. 15 N., R. 1 E. These springs are thermal, the average temperature for the group being about $85^{\circ} \mathrm{F}$. They issue on the north slope of the Tierra Amarilla anticline, and some of them are more than 200 feet above the Rio Salado, showing that the water is under appreciable head. This water comes to the surface near the contact of the Chinle (?) formation and Wingate sandstone, but the actual contact is concealed by a great accumulation of calcareous tufa. This deposit of tufa covers the north slope and the surface of the hill over an area at least 11/2 miles in length and almost onehalf mile in width. On the summit of this hill, which is the axis of the Tierra Amarilla anticline, there are many craters, some as much as 20 feet in diameter and 30 feet or more in depth, which mark the site of extinct thermal springs, the water in which must have been at considerably greater head than the present springs. Some of the deposits are shown in Plate $8, B$. An analysis of water from one of the springs on the north slope (No. 12, p. 78) shows that it is highly mineralized.

\section{PHILLIPS SPRINGS}

The Phillips Springs issue at the north end of the Sierrita Mesa, mostly along the Arroyo Penasco, near the west edge of the Jemez Indian Reservation. Their arrangement is in line with the major Sierra Nacimiento overthrust. There are at least a dozen large springs and a number of smaller ones, extending from a point about half a mile west of the highway for a distance of about $11 / 2$ miles to the east. The Swimming Pool Spring has built up a crater at least 50 feet high, with a gentle slope on the outside and an almost vertical wall on the inside. It is about 35 feet in diameter, 
and the water is 40 feet or more deep. This water has a decidedly saline taste. Its temperature is $70^{\circ}$. The water spills over the edge of the crater at several places and deposits calcium carbonate. The flow was estimated at about 8 gallons a minute, and there is: a considerable bubbling of gas in the center of the pool. An analysis. of a sample of water from this spring is given as No. 13 (p. 78). This spring, like most others in this area, issues along a fault.

There are a number of craters of extinct springs along a line extending northward parallel to the mountain and just north of the Arroyo Penasco and west of the Poleo hogback, which defines the west. limit of the mountain. (See pl. 10,B.) Some of them are 50 feet in diameter and at least 50 feet deep. These craters, also, were formed by deposition of calcareous material as the water spilled over the rim; the inside wall is almost vertical, but the outside slope is gentle, the configuration thus being similar to that of the Swimming Pool Spring. The amount of material deposited by these extinct springs is great, as shown by the fact that for a mile or more to the west the high-level gravel above the stream has been cemented by calcium carbonate. The distribution of this calcareous deposit, which lies just west of the Poleo outcrop, is shown on Plate 1.

\section{SOURCE AND ORIGIN OF THE SPRING WATERS}

A study of some of the water analyses (p. 78) together with the gas analyses (p. 89) furnishes a clue as to the origin of the waters from the springs. Samples 17 and 18 were collected at Sulphur Spring, north of Upper Canones, up San Diego Canyon. These waters are thermal and come from volcanic rocks that were erupted in late Tertiary time. They are noteworthy for their high content of sulphur, high silica and alumina, and low bicarbonate and chloride as compared with other springs.

Sample 22 was collected at the Soda Dam, near Jemez Springs. The water comes from the rocks near the contact of the pre-Cambrian granite and the Magdalena group. It contains much less silica, little or no alumina, and is very low in the sulphate radicle but high in the bicarbonate and chloride radicles. This water has doubtless dissolved considerable calcium as bicarbonate and considerable salt $(\mathrm{NaCl})$ from the marine beds near by. Probably it is largely meteoric water which has become thermal as a result of circulation underground in proximity to the buried masses of igneous rock which have not yet cooled; at least, the water is not characteristic of the waters from areas of igneous rocks.

Samples 11 and 12 came from the San Ysidro Springs, near the south end of the Sierra Nacimiento. These waters seem to be a combination of the two types-they represent original volcanic 
waters, modified by the addition of meteoric waters. That the water in the San Ysidro Springs, especially in the south group, comes from the mountains to the north is further indicated by the fact that it is under considerable head, coming to the surface 200 feet or more above the Rio Salado Valley. The mountain area to the northeast is the only one where such a head might be produced. The deposits of extinct springs on the summit of the Tierra Amarilla. anticline indicate that the head was formerly considerably greaterthan 200 feet above the present stream. (See pl. 8, B.) The analyses show that the gases contained in the two thermal spring. waters, represented by samples 11 and 12, are mostly carbon dioxide $\left(\mathrm{CO}_{2}\right)$ nitrogen $\left(\mathrm{N}_{2}\right)$, and hydrogen sulphide $\left(\mathrm{H}_{2} \mathrm{~S}\right)$. It is therefore evident that these waters are similar to those of volcanic regions. $^{95}$ The absence of hydrocarbons shows that the gases are not of organic origin.

Analyses of gases from spring waters in Sandoval County, N. Mex.

[W. P. Yant, U. S. Bureau of Mines, analyst. Test for helium by H. S. Kennedy. The, numbers used in this table for the gas analyses correspond with the numbers used in the table on p. 78 and in pl. 9 for the water analyses of the same springs]

\begin{tabular}{|c|c|c|c|c|c|c|}
\hline & 11 & 12 & 13 & 17 & 18 & 22 \\
\hline $\begin{array}{l}\text { Temperature } \\
\text { Gas per cubic centimeter of water-cubic centimeters } \\
\text { Carbon dioxide }\left(\mathrm{CO}_{2}\right) \\
\text { Oxygen }\left(\mathrm{O}_{2}\right) \\
\text { Hydrogen sulphide }\left(\mathrm{H}_{2} \mathrm{~S}\right) \\
\text { Other combustible gases. } \\
\text { Nitrogen }\left(\mathrm{N}_{2}\right) \\
\text { Helium }(\mathrm{He})\end{array}$ & $\begin{array}{r}68 \\
0.45 \\
97.5 \\
.5 \\
.0 \\
.0 \\
.0 \\
.0\end{array}$ & $\begin{array}{r}86 \\
0.22 \\
96.7 \\
.6 \\
.0 \\
.0 \\
2.7 \\
.0\end{array}$ & $\begin{array}{r}70 \\
0.07 \\
70.4 \\
8.3 \\
.0 \\
.0 \\
21.3 \\
-. .0\end{array}$ & $\begin{array}{r}110 \\
0.14 \\
85.9 \\
1.1 \\
7.1 \\
.0 \\
5.9 \\
.0\end{array}$ & $\begin{array}{r}76 \\
0.19 \\
77.9 \\
1.1 \\
20.1 \\
.0 \\
.9 \\
.0\end{array}$ & $\begin{array}{r}104 \\
0.26 \\
82.8 \\
3.3 \\
.0 \\
.0 \\
13.9 \\
.0\end{array}$ \\
\hline
\end{tabular}

Although no chemical data are available concerning the origin of the water of the other springs, the writer believes that all the springs along the southern slopes of the Sierra Nacimiento are of the same origin. The similarity of the water from the Kaseman well No. 1 (analysis 16), which is near the Phillips Springs, supports this. conclusion.

\section{PLANTS AS INDICATORS OF GROUND WATER}

There are some plants which extend their roots down to ground water and obtain their water from this source. ${ }^{96}$ Greasewood (Sarcobatus vermiculatus) is regarded by Meinzer as a most important indicator of ground water, as it extends its tap ropts 40 , feet or more. to the water. This plant is not abundant in this area, but along the Arroyo Penasco west of the Sierrita Mesa, where the stream is fed by

\footnotetext{
\% Allen, E. T., Chemical aspects of volcanism, with a collection of the analyses of volcanic gases : Franklin Inst. Jour., vol. 193, pp. 29-80, 1922:

${ }^{\infty}$ Meinzer, O. E., Plants as indicators of ground water: U. S, Geol. Survey Water. Supply Paper 577, p. 1, 1927.
} 
a number of springs, there is a considerable stand of it. Associated with the greasewood is a noticeable amount of hop sage (Grayia spinosa), but this plant was observed on some rather dry, barren slopes, where the water table is apparently a considerable distance below the surface.

\section{SURFACE WATER}

Streams.-The water from the streams in this area, such as the Rio Grande, Rio Puerco, Jemez Creek, and most of their tributaries, is used for irrigation. The areas under irrigation are described in more detail in the township and land grant descriptions below. These surface waters are hard and very similar in composition to the water obtained in shallow wells or springs near by. The chemical character of the water in Jemez Creek is shown by analysis 15 (p. 78) ; it contains only 466 parts per million of dissolved solids. Water from the Rio Salado 3 miles above its junction with Jemez Creek (see analysis 14) was found to contain 11,040 parts per million of dissolved solids. The quality of a surface water varies with the amount of precipitation-during times of increased precipitation there will be less dissolved mineral matter in the water than during times of drought.

Tanks.-Many ranchers in this region depend upon surface reservoirs or tanks supplied by storm run-off for supplies of water for stock, and some of them utilize such water for drinking and domestic purposes. Tanks are probably most generally used in the area west of Cuba, although supplies of ground water may be obtained in this area by drilling several hundred feet, perhaps less, into the strata of the Nacimiento group. A tank is made by constructing a dam across an arroyo. The dam usually consists of a foundation of stone and brush, such as piñon or cedar, covered with clay and mud.

\section{DESCRIPTIONS OF TOWNSHIPS AND LAND GRANTS}

In Sandoval County there are a number of old Spanish land grants-tracts of land given to individuals by the Spanish Crown or by the Mexican Government, usually in recognition of military or civil service. There are also several tracts which the Mexican Government set aside for the Pueblo Indians. When this territory was ceded to the United States by Mexico, in 1848, the orners of these grants, or their heirs, still maintained the title. Only the land outside of the grants became part of the public domain and was surveyed and subdivided into townships and sections. In the following pages the geology, drainage, and ground-water conditions are described by townships or by grants. 


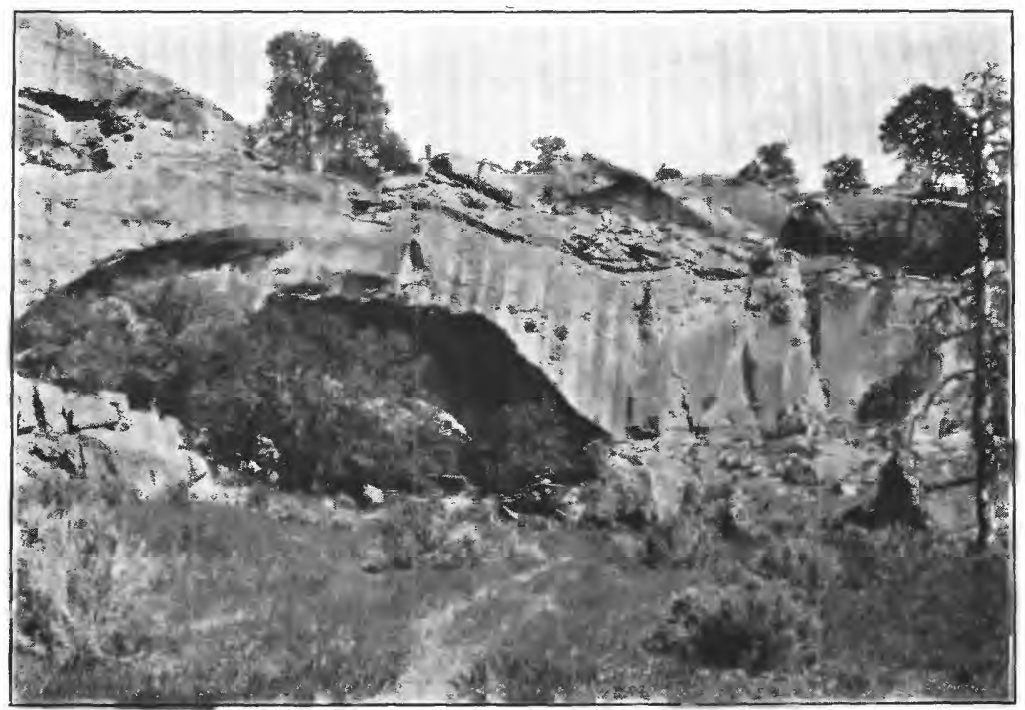

A. LARGE SPRING BELOW SANDSTONE OF PUERCO FORMATION, SHOWING NATURAL BRIDGE NEAR THE NORTHERN PART OF THE WEST LINE OF SEC. 4, T. 19 N., R. 2 W.

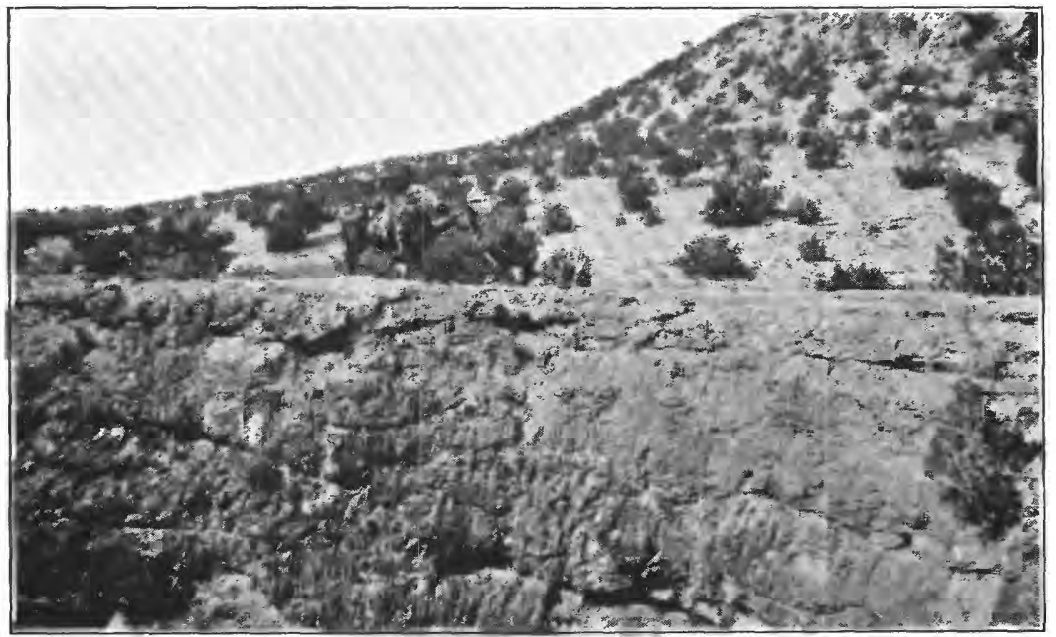

B. CRATER OF EXTINCT SPRING ONE-EIGHTH OF A MILE NORTH OF ARROYO PENASCO NEAR SIERRA NACIMIENTO OVERTHRUST, IN SOUTHEASTERN PART OF OJO DEL ESPIRITU SANTO GRANT

The crater is ahout 50 feet in diameter and 40 feet deep. The inside wall is essentially vertical. There are several such craters near by. 

T. 23 N., R. 1 W.

Only the south half of T. 23 N., R. 1 W. (secs. 19 to 36) is in Sandoval County, and this is the only part described in this report; the northern sections are in Rio Arriba County. San Pedro Mountain extends into the eastern part of this township, and the altitude ranges from about 9,300 feet in the southern part of sec. 36 to less than 7,400 feet in sec. 32 in the valley of the Rio San Jose, which is the principal stream draining the township. The Continental Divide extends northeastward across the western part of the township.

The geologic structure in the eastern tier of sections is complicated by faulting, and the rocks from the pre-Cambrian to the base of the Morrison formation are exposed. Along the hogback formed by the Morrison and Dakota (?) in secs. 23, 26, and 35 the rocks stand nearly vertical, and the prevailing strike is north, but the dip diminishes westward as younger strata are exposed, and the strike changes to northeast, so that in the southwestern part of the township the Wasatch formation strikes N. $55^{\circ}$ E., and dips $2^{\circ} \mathrm{NW}$.

Dry farming is carried on successfully by the ranchers along the San Jose and its tributaries. Beans are the principal crop.

In the NW. $1 / 4$ NW. $1 / 4$ sec. 35, T. 23 N., R. 1 W., along the north bank of the San Jose, A. C. Fish has a drilled well 105 feet deep in which the water level stands 23 feet below the surface. The water of this well is hard and nonpotable. In the NE. $1 / 4$ SE. $1 / 4$ sec. 35 near the line of sec. 36, there is a spring along the fault contact between the Magdalena group and the lower reddish shales of the Morrison formation. The estimated yield of this spring is about 0.25 secondfoot, and it is reported never to go dry. Mr. Fish has constructed a ditch which carries the water down the valley to a tank in the NW. 1/4 NW. $1 / 4$ sec. 35 , where he utilizes it for domestic and stock use. The water, though slightly hard, has a very pleasant taste.

In the NW. $1 / 4$ sec. 26 , on Frank Mahan's ranch, there is a drilled well 75 feet deep in which the water level is 50 feet below the surface. This water, which apparently comes from the Mancos shale, is hard and nonpotable. There is a spring on the line between secs. 35 and 36, in the Jemez National Forest, which yields water of excellent quality.

No drilled wells were found in the San Jose Valley, but there is probably little doubt that in the western part of this township, near the river, considerable supplies of ground water might be obtained by drilling wells a few hundred feet into the Wasatch formation or into the underlying Nacimento group at greater depth-in fact, a flowing well is entirely possible.

$3616-31-7$ 
Along the San Jose and in the lower courses of the tributaries, where the largest farming tracts are located, it would at the present time be too expensive to drill to the Mesaverde or the Dakota (?) sandstone, both of which are generally water bearing.

\section{T. 22 N., R. 1 W.}

The geology of T. 22 N., R. 1 W., is very similar to that of T. 23 N., R. $1 \mathrm{~W}$. The eastern part of the township is rugged and mountainous. Adjacent to the west slope of San Pedro Mountain the sedimentary beds stand nearly vertical and the strike is north. Farther west the dip decreases, until in the western part of the township it is not more than $1^{\circ} \mathrm{W}$.; here the strike is east of north.

The largest tributaries to the San Jose that drain this township, named from north to south, are Arroyo Salado, ${ }^{97}$ Arroyo Naranja, La Jara Creek, and Rito de los Pinos. All these streams, with the exception of La Jara Creek, are probably intermittent, but in 1925, which was a rainy year, all of them contained water. The water from the streams is diverted by the inhabitants of the valleys and used for irrigating small tracts of land.

There are few wells in this township. Most of the ranchers utilize surface water, either taking it directly from the streams tributary to the San Jose, or storing the water from these streams in tanks for consumption throughout the year. In general the water from the small mountain streams is potable, though hard, and on the whole is superior in quality to the water obtained from shallow wells.

It is reported that Onofre Garcia has a dug well 33 feet deep and $31 / 2$ feet in diameter in the NW. $1 / 4$ sec. 33 , on a bench about 20 feet above the bed of La Jara Creek, where the Wasatch formation is at the surface. This well is said to contain 6 feet of water that is potable and similar in quality to surface water.

Dr. M. C. Wiley reports that he has a well in the NE. 1/4 sec. 31, which is 15 feet deep and contains about 5 feet of water, and that there has always been an abundance of water. This water comes from alluvium or from the Wasatch formation.

In 1925 , when the investigation was made, there were no drilled wells in this township. It is believed that wells drilled a few hundred feet into the rocks of the Wasatch formation or the Nacimiento group in the central and western parts of this township will yield fairly satisfactory water for domestic and stock use and possibly also for irrigation. The water may be expected to rise to a considerable height in the wells, and a flowing well may even be obtained in the valley of San Jose Arroyo, in the vicinity of San Jose Lake.

g7 This is a different stream from the Rio Salado, which fiows south of the Sierra Nacimiento into Jemez Creek. 
The valley of the San Jose in the southern part of this township was regarded as a favorable place for drilling a test well to determine the artesian possibilities, and in a recommendation of an earlier date such a tract was designated. (See pp. 1, 2, 84.)

The Mesaverde formation and the Dakota (?) sandstone are too far below the surface to be considered as aquifers that might, at the present time at least, be economically utilized for developing water supplies.

\section{T. 21 N., R. 2 W.}

Opportunity was not afforded for a detailed study of T. 21 N., R. $2 \mathrm{~W}$., but the township was traversed on one reconnaissance trip. The prevailing strike is northeast, and the beds dip $2^{\circ}$ to $5^{\circ} \mathrm{NW}$. The rocks of the Nacimiento group are at the surface over most of the township, but in the northern part the Wasatch is the surface formation. Ground-water supplies can doubtless be obtained by drilling a few hundred feet into the sandstones of either the Wasatch or the Nacimiento. If water of inferior quality is obtained from some shale bed it should be cased off and drilling should proceed until a water-bearing sandstone bed is encountered. Ground water may also be obtained by digging shallow wells in the arroyos; water so obtained would come from the alluvium and from sand or sandstone beds.

\section{T. 21 N., R. 1 W., INCLUDING CUBA}

In the eastern part of T. $21 \mathrm{~N}$., R. $1 \mathrm{~W}$., the rocks adjacent to the mountain are deformed by faulting and folding, but in the central and western parts the strata dip gently northwestward. The Rio Puerco and its principal tributaries, the San Jose from the north and Nacimiento Creek from the east, drain this township. The valley of the Rio Puerco and its tributaries in this township are devoted to dry farming, and in some places where the water has been diverted for irrigation there are alfalfa fields.

In the NE. $1 / 4$ sec. 20, T. 21 N., R. 1 W., Pulidor Olivas has a dug well about 40 feet deep, with 3 feet of water in it. The water is of poor quality for drinking and hard for washing but is said to be satisfactory for irrigating the garden. Near the center of the S. $1 / 2$ sec. 28 , on the side of an arroyo tributary to Nacimiento Creek, there is a dug well beside the road, in which the water stands 15 feet below the surface. The water is hard, and its taste is only fair. It comes from a soft sandstone near the base of the Puerco formation. Near the center of sec. 33, in the valley of Nacimiento Creek, Gabriel Montoya has a dug well about 18 feet deep, which contains about $31 / 2$ feet of water. This water is hard, but the taste is good, and it is said to be satisfactory for domestic and stock use. The water is 
obtained from a sandstone near the base of the Puerco formation. On Reyes Jaramillo's ranch, in the NE. 1/4 sec. 33, there is a dug well 22 feet deep containing about 4 feet of water, which is hard and, though potable, has an unpleasant taste. The water is apparently derived from the alluvium along Nacimiento Creek.

There are several springs in this township. In the NW. 1/4 sec. 34, on the ranch of Mrs. Paulina Montoya, there is a spring 25 feet or so above the bed of Nacimiento Creek which gives rise to a marshy tract about 100 feet square. The exact geologic relations are concealed by marsh grass and alluvium, but the spring is within the area of the outcrop of Lewis shale, a condition which is apparently unique for the Lewis shale. On the ranch of Esquipula Gallegas, in the SW. $1 / 4$ sec. 10 , there is a dug well 12 feet deep, which was originally a spring but has been deepened. It yields a water that is hard but of satisfactory taste.

In the SE. $1 / 4$ sec. 27 Aebal Sales dug 45 feet into the Lewis shale without obtaining water.

The Lewis shale, the Nacimiento group, and the Wasatch formation are the outcropping formations over most of this township, and in general it may be said that shallow wells dug into the rocks of the Nacimiento group or the Wasatch formation or into alluvium derived from either of these yield a hard, rather highly mineralized water, which in some places has a pleasant taste but in others is unsatisfactory for drinking and domestic use. On the other hand, wells drilled 200 feet or more into the Puerco and Torrejon formations of the Nacimiento group or into the Wasatch would probably yield water of a quality fairly satisfactory for most purposes but possibly not for irrigation. Only meager supplies of water of poor quality may be expected from the Lewis shale in either shallow dug wells or in deeper drilled wells.

The prospects of obtaining a flowing well by drilling a few hundred feet into the Wasatch or underlying Nacimiento group are regarded as worth testing; the localities recommended for the tests are secs. 6 and 7, T. 21 N., R. 1 W., or sec. 31 , T. 22 N., R. 1 W.

The town of Cuba is the economic center of a considerable dry farming and stock raising district. It has several general merchandise stores, a Catholic school and church, a garage, and other places of business. At the time the field work was done the community was very much in need of a water supply, being dependent upon shallow dug wells, which generally yield water of rather poor quality. The water from the well at Young's store, which is 22 feet deep and has about 4 feet of water in it, contains over 2,700 parts per million of total dissolved solids (see analysis 3, p. 78) and has a hardness of 1,285. This well apparently obtains its water from the 
alluvium of the Rio Puerco. The well at the Catholic school is $\mathbf{1 6}$ feet deep; the bottom of the well encounters a sandstone of the Puerco formation, but the water, though hard, has a much pleasanter taste than that from the Young well. About 2,000 gallons a day is reported to be pumped from this school well by a gas engine. There is another dug well near the center of the town that is used by many of the inhabitants, and it yields a fairly pleasant-tasting hard water.

There is apparently only one drilled well in Cuba. It is owned by $\mathrm{A}$. Eichwald and is but little used. The well is reported to be 150 feet deep, with the water level 110 feet below the surface. The analysis, No. 4, shows that the water contains but 872 parts per million of total dissolved solids and is far superior to the shallow ground water in the Young well. The water encountered in the sandstones of the Puerco formation in this well is probably of better quality than the analysis indicates, because the highly mineralized water near the surface is not cased off and is therefore intermingling with the water from the deeper sandstone.

It is believed that the town of Cuba can probably solve its water problem by drilling wells to a depth between 125 and 300 feet, into the Puerco formation. Wells of this depth here are not expected to flow, but the water will probably rise to a considerable height in the wells. If the hard water near the surface is tightly cased off, wells 150 feet deep or more may yield soft water, but the quality of the water can not be predicted with certainty. Such water may not be satisfactory for irrigation.

Below the Puerco formation at Cuba there is about 1,500 feet of dark-gray Lewis shale, which is not water bearing. Below the Lewis shale is the Mesaverde formation, which might be expected to yield supplies of potable water, and it is possible that water so obtained might rise to the surface and produce a flowing well, but the cost of drilling 1,600 to 1,800 feet in order to test the waterbearing character of the Mesaverde formation would be very great.

\section{T. 20 N., R. 2 W.}

The Wasatch, Puerco, and Torrejon formations crop out over T. 20 N., R. 2 W., except in the southeast corner, where the Lewis shale is at the surface. The mean strike of the rocks is about N. $55^{\circ}$ E., and the dip ranges from $2^{\circ}$ to $5^{\circ} \mathrm{NW}$. The alternating hard and soft beds give rise to several cuestas with gentle northwestward slopes. In the southern part of this township there is a cuesta formed by the sandstone indicated as bed 20 of section 18 (p. 52), and in the northern part of the township a somewhat similar cuesta is formed by the massive sandstone indicated as bed 8 of section 18 . 
Arroyo Chihuile enters the northwestern part of this township from the north, then turns eastward across the central part. The valley has been developed in the shales and soft sandstones that occupy the interval between bed 20 and bed 8 .

The massive sandstone (bed 20), which crops out over a considerable area in the southern part of this township, yields good water. In the NE. $1 / 4$ sec. 31 , George E. Conlisk has a well only 7 feet deep and 4 feet in diameter dug into this sandstone. The water has a pleasant taste as compared with many other waters of this region, and an analysis (No. 2, p. 78) shows that it contains only 79 parts per million of total dissolved solids and that it is soft. Water obtained in other shallow wells in this sandstone will probably be of similiar quality. Over much of the outcrop of this sandstone there is a considerable stand of pine timber in addition to the ordinary piñon.

North of this sandstone outcrop there is a barren sagebrush desert, which is crossed by Arroyo Chihuile, itself clogged with sand. This arroyo apparently contains no greasewood or other indicators of shallow ground water, in contrast to the valleys of the Rio Puerco and its tributaries in T. 20 N., R. 1 W. In the northern part of this township the continuity of sagebrush is interrupted by stands of piñon on the sandstone rim rock of the interstream divides.

There is apparently little doubt that supplies of ground water might be obtained in the central and northern parts of T. 20 N., R. 2 W., by drilling wells several hundred feet deep into the massive sandstone formation (bed 20), which crops out in the southern part of the township. Such supplies of ground water would almost certainly be satisfactory for domestic and stock use, and though the water would probably contain some sodium bicarbonate, it might also be satisfactory for irrigation.

T. 20 N., R. 1 W.

In the two tiers of sections in the extreme eastern part of T. 20 N., R. $1 \mathrm{~W}$., the rocks are deformed by sharp folding. The prevailing dip is $90^{\circ} \mathrm{W}$, and the entire geologic section of San Pedro Mountain from the pre-Cambrian to the Puerco formation is well exposed from east to west. In places faulting is a conspicuous feature. A north-south fault up the valley has lower Morrison shales on both sides, but another fault farther east brings the Todilto formation against the pre-Cambrian. A hogback formed by the Dakota (?) and Morrison formations is shown in Plate 4, $B$.

The Rio Puerco flows southward across the western part of the township, and Arroyo Senorito, its largest tributary, flows across the township from northeast to southwest. 
There is a considerable stand of greasewood growing along the flats bordering the Rio Puerco and also in the lower part of the valley of Arroyo Senorito and its eastern tributary-a condition which suggests that ground water is relatively close to the surface. The greasewood is especially luxuriant in the northern part of the township, where the Rio Puerco dissects the massive cliff-forming sandstones of the Puerco formation, which are probably water bearing. It is almost certain that supplies of ground water may be obtained along the Rio Puerco and its tributaries, but it is probable that any shallow water so obtained will be hard and highly mineralized. The prospects of obtaining potable water are especially poor in the area of the Lewis shale.

All of secs. 21 and 28, the southern part of sec. 20, the northern part of sec. 29 , the NW. $1 / 4$ sec. 33 , and probably most of secs. 30 and 31 are to be regarded as favorable territory for prospecting for artesian flows in the Mesaverde formation. The farther west a well is located in this tract the greater the thickness of Lewis shale through which it will be necessary to drill in order to reach the Mesaverde; but on the other hand, in the western part of the tract, in proximity to the Rio Puerco, the surface is lower and therefore a greater head is to be expected. The southern part of sec. 27 and the northern part of sec. 34, which are within the area of the Mesaverde outcrop, are situated favorably, so far as topography and geologic structure are concerned, for drilling into the lower sandstone of the Mesaverde to test the artesian prospects. Water so obtained will doubtless be under artesian head, but it may not rise to the surface.

On Mr. Bletcher's ranch in the central part of the N. 1/2 sec. 11, T. 20 N., R. 1 W., along Arroyo Senorito, there is a dug well 30 feet deep with a water level 12 feet below the surface. Although the bottom of the well extends into the Lewis shale, the water is in all probability derived largely from the alluvial gravel along the arroyo. This water is hard for washing but has a good taste.

In the belt of deformed rocks adjacent to the mountains there are seeps at several places, and in the SE. $1 / 4$ sec. 36 there is a spring with an estimated yield of 2 to 5 gallons a minute. The water comes from granitic débris, but the spring is in an area that has been considerably disturbed by faulting and may be genetically related to a fault.

\section{T. 19 N., R. 2 W.}

In the northwest corner of T. 19 N., R. 2 W., the massive cliff-forming sandstone of the Puerco formation (bed 20, of sec. 18, p. 52), gives rise to a southward-facing escarpment. This is the same sandstone that is at the surface in the southern part of T. $20 \mathrm{~N}$., R. $2 \mathrm{~W}$. The Lewis shale is at the surface in the northeastern and 
central parts of the township, and the Mesaverde formation crops out over the southern half. The prevailing strike of the rocks is about N. $45^{\circ} \mathrm{E}$, and the dip is between $3^{\circ}$ and $6^{\circ} \mathrm{NW}$. The resistant sandstones of the Mesaverde give rise to a series of northeastward-trending escarpments and in the southern part of the township, where the Mesaverde is the surface formation, the topography is rugged. Where the Lewis shale is at the surface the topography is gently undulating. Arroyo Piedra Lumbre drains most of this township.

There are a number of springs in the southern part of the township. Most of them issue from the bluff along a drainage line at the contact where sandstone rests on impervious shale. On Robert H. Roden's ranch, in the SW. $1 / 4$ sec. 26 , there is a spring at the contact of the massive top sandstone of the Mesaverde and the underlying shale of the Mesaverde. This spring, though reported to go dry in very dry seasons, generally waters 10 or 12 head of stock. The water has a pleasant taste and is probably similar in quality to the water of $\mathrm{O}$. K. Ash's spring, in the NE. 1/4 NW. 1/4 sec. 26. Mr. Ash's spring also issues at the base of the massive top sandstone of the Mesaverde formation. The yield probably does not exceed a few gallons an hour but could doubtless be increased by further excavation. The water has a pleasant taste, and an analysis (No. 1, p. 78) shows that though hard it contains only 229 parts per million of total dissolved solids. It is probably satisfactory for most farm uses. The presence of these and other springs along the outcrop of the Mesaverde in this township indicates that the sandstones of the Mesaverde formation are water bearing.

Along Arroyo Piedra Lumbre and its tributary from the west there is a considerable amount of relatively flat country which could probably be cultivated with profit if water for irrigation were available. There is some prospect that a water supply could be developed by drilling wells a few hundred feet into the Mesaverde. On the flood plain bordering Arroyo Piedra Lumbre, in secs. 21, 22, 23, $28,29,32$, and 33 , and on the flat bordering the tributary in secs. 20 and 21 , the water may rise sufficiently high to produce flowing wells. However, before any extensive development is undertaken test wells should be drilled to determine if an adequate supply is available, and samples of the water should be analyzed to determine its fitness for irrigation. Probably the most desirable location for testing the artesian prospects of this area is near the junction of Arroyo Piedra Lumbre and its tributary from the northwest, either in the S. $1 / 2$ sec. 21 or in the NW. $1 / 4$ sec. 28.

On the mesa in the northwestern part of the township supplies of ground water for domestic and stock use can doubtless be obtained 
by digging shallow wells into the sandstone that caps the mesa. The quality of the water will probably be similar to that shown by analysis 2 (p. 78), representing water obtained from the same sandstone in the next township north, which is of good quality.

Near the northern part of the west line of sec. 4 there is a large spring under an arch of rock that suggests a natural bridge. (See pl. 10, A.) On its roof are Pueblo paintings of birds and other figures.

The Lewis shale in this township is not a satisfactory water-bearing formation. In the NW. $1 / 4$ sec. 20 , on the flat bordering the arroyo, S. Zambrano has a dug well 39 feet deep, 6 feet square at the top, and 5 feet square at the bottom. The water level is 21 feet below the surface. He reports that it has never gone dry and that he has watered as many as 1,500 head of sheep. The water, however, is hard and highly mineralized, and is unsatisfactory for domestic use. The first water is said to have been encountered in a sand in the Lewis shale at a depth of 24 feet. The well is equipped with a hand pump and a windmill. A log of the well, furnished from memory by Mr. Zambrano, follows:

Log of Zambrano well in the NW. 1/4 sec. 20, T. 19 N., R. 2 W.

\begin{tabular}{|c|c|c|c|}
\hline Formation & Lithologic character & $\begin{array}{c}\text { Thick- } \\
\text { ness } \\
\text { (feet) }\end{array}$ & $\begin{array}{l}\text { Depth } \\
\text { (feet) }\end{array}$ \\
\hline Alluvium.-.-.-.... & Gumbo & 7 & 7 \\
\hline (?) Do & $\begin{array}{l}\text { Fine sand } \\
\text { (?) }\end{array}$ & $\begin{array}{l}8 \\
9\end{array}$ & $\begin{array}{l}15 \\
24\end{array}$ \\
\hline Lewis shale............ & $\begin{array}{l}\text { Shale, with streaks of sand. Shells abundant } 4 \text { feet from top. } \\
\text { First water at } 24 \text { feet. }\end{array}$ & 15 & 39 \\
\hline
\end{tabular}

In the NE. $1 / 4$ sec. 10 Sam Houston dug 70 feet into the Lewis shale without obtaining water and abandoned the hole at that depth. The location is not near any arroyo where ground water is to be expected to occur close to the surface, but the probabilities are that if the well is deepened water will be obtained within 25 feet.

T. 19 N., R. 1 W.

The geology of T. 19 N., R. 1 W., is very similar to that of T. $20 \mathrm{~N}$., R. $1 \mathrm{~W}$. In the eastern part of the township the rocks strike north and $\operatorname{dip} 60^{\circ}$ to $90^{\circ} \mathrm{W}$. Toward the west the dip decreases and the strike changes until it is about N. $45^{\circ} \mathrm{E}$. The Rio Puerco flows southward across the western part of this township, and Arroyo de los Pinos, which flows into the Puerco, and its tributary, Arroyo San Miguel, are the principal streams draining it. The large hogback formed by the Dakota (?) and Morrison formations and the somewhat higher hogback formed by the Poleo sandstone 
are striking topographic features. A view east, north, and northwest from the Poleo hogback is given in Plate 4, $A$. In the southern part of the township the resistant sandstones of the Mesaverde formation have given rise to a broad table-land known as La Ventana Mesa. West of the mountain front, in the area of the Lewis shale, the surface is undulating, but to the south, where the Mesaverde is at the surface, the topography is very rough and much dissected.

The flood plain of the Rio Puerco in the western part of this township is regarded as a favorable place for testing the artesian prospects of the sandstones of the Mesaverde formation. The eastern part of secs. $6,7,18$, and 19 , the western part of secs. 5, 8, 17, 28 , and possibly the west half of sec. 29 are included in the tract that is regarded as favorable. Along the flood plain of the Rio Puerco north of the mouth of the Arroyo de los Pinos, in a tract embracing the E. $1 / 2$ sec. 7 , NE. $1 / 4$ sec. 18 , SW. $1 / 4$ sec. 17, NE. $1 / 4$ NE. $1 / 4$ sec. 19 , and NW. $1 / 4$ sec. 20 , the uppermost massive sandstones of the Mesaverde formation are close to the surface, and here almost the entire Mesaverde section may be tested without drilling through any considerable amount of Lewis shale. This area was recommended for testing the artesian qualities of the Mesaverde along the Rio Puerco. (See pp. 2, 84.) From this locality the thickness of Lewis shale that must be drilled through in order to reach the Mesaverde increases progressively upstream along the Rio Puerco. A well drilled at any locality within a mile south of this tract would penetrate several hundred feet of Mesaverde rocks, some of which would probably prove to be water-bearing, but the upper part of the Mesaverde formation would not be tested at such a locality.

Greasewood grows along the flood plain of the Rio Puerco throughout most of this township, indicating that ground water is close to the surface, but the stand seems to be more luxuriant in the southern part of the township, where the Rio Puerco crosses the Mesaverde outcrop, than in the northern part, where it crosses the Lewis shale.

At La Ventana, in the NW. $1 / 4$ sec. 31 , there is a well about 40 feet deep equipped with windmill and storage tank. The water from this well which was used by the several families living at La Ventana in 1925 , is hard, but the taste is fair. It is probably representative of the water that is to be expected from shallow wells along the Rio Puerco in this township.

\section{T. 18 N., R. 2 W.}

In most of T. 18 N., R. 2 W., the Mesaverde formation is at the surface. The strike ranges from N. $35^{\circ}$ E. to N. $80^{\circ}$ E., and the prevailing dip is $3^{\circ}$ to $6^{\circ} \mathrm{NW}$. The erosion of the alternating hard 
and soft beds in the Mesaverde formation has given rise to a rough, dissected topography. The eastern part of the township is drained by tributaries to the Rio Puerco and the western part by the Arroyo Piedra Lumbre and its tributaries.

The ground-water possibilities of this township were not investigated in detail, but it is very probable that the sandstones of the Mesaverde formation give rise to small seeps and springs, as they do in T. 19 N., R. 2 W., and there is little doubt that these sandstones will yield supplies of water to dug and drilled wells. It is also possible that flowing wells might be obtained by drilling into the Mesaverde sandstones at some place along Arroyo Piedra Lumbre. In general, water obtained from the Mesaverde formation will probably be of a quality satisfactory for domestic and stock use. The water obtained from shallow dug wells will be hard, and that obtained from wells 200 feet or more deep will probably be softer.

T. 17 N., R. 3 W.

Only the eastern part of T. 17 N., R. 3 W., was visited. The rocks of the Mesaverde formation are at the surface over most of this township, and they conform to the regional structure, the strike being northeast and the dip $2^{\circ}$ to $4^{\circ} \mathrm{NW}$. Supplies of ground water can doubtless be obtained from shallow dug wells or somewhat deeper drilled wells in the sandstones of the Mesaverde formation.

\section{T. 17 N., R. 2 W.}

The southeastern part of T. 17 N., R. 2 W., east of the Rio Puerco, is within the Ojo del Espiritu Santo grant (see p. 110), and is included in the description of that tract. The Rio Puerco flows southwestward across this township, and the basal beds of the Mesaverde formation crop out in a bluff on the west side of the stream, the Mancos shale being at the surface throughout the remainder of the township. The rocks strike northeast and dip from $2^{\circ}$ to $4^{\circ} \mathrm{NW}$. Wells dug into the alluvium adjacent to the Rio Puerco will probably yield hard but potable water, but wells dug into the Mancos shale will generally yield water of poor quality. The water that may be expected from the Mancos or from the underlying Dakota sandstone will doubtless be similar in character to that occurring elsewhere in these formations.

The sandstones and coal beds of the Mesaverde formation will doubtless yield supplies of water satisfactory for most uses, and wells drilled into these rocks in some of the arroyos in the northwestern part of the township will yield water that may be expected to rise in the wells, but flows are not probable. 


\section{T. 16 N., R. 3 W., INCLUDING CABEZON}

The Mancos shale is at the surface over most of T. 16 N., R. 3 W., but in the northern part of the township the basal beds of the Mesaverde form a very distinct rim rock. The west slope of Cabezon Peak is in the township, also Cerro Chato, La Abra de los Cerros, and Cerro de los Cuates. These peaks are described on pages 66-69. The prevailing strike of the rocks is northeast, and the prevailing dip is $1.5^{\circ}-3^{\circ} \mathrm{NW}$.

The following data regarding ground water at the village of Cabezon have been furnished by Mr. R. F. Heller, of that place. He has a dug well 35 feet deep and 3 feet in diameter on a bench about 100 yards west of the Rio Puerco; the well contains about 3 feet of water, which is hard, and, though its taste is not pleasant, it is potable. He has another well about 15 feet higher, which is about 30 feet deep, but the water in this is so alkaline that stock will not drink it. There is a drilled well in the center of the village, which is 80 feet deep, but its water also is so mineralized that stock refuse to drink it. Mr. Heller has water for domestic consumption hauled from the spring at Guadalupe.

There was reported to be a spring on the southwest slope of Cabezon Peak, but it was dry when visited.

Supplies of hard water, somewhat mineralized but satisfactory for drinking, might be obtained by digging shallow wells into the alluvium along the Rio Puerco and Chico Arroyo, but water obtained from the Mancos will generally be highly mineralized and unsatisfactory for most uses, except possibly irrigation.

A well drilled to the Dakota (?) sandstone, which here would be 1,500 feet or more below the surface, would doubtless yield considerable water, and such a well located along either of the major streams of this township might yield a flow, but there are not sufficient data available at this time upon which to base a prediction of the chemical character of the water. Any water obtained from the Mancos shale should be cased off to prevent additional mineralization of the water in the Dakota (?) sandstone.

\section{T. 15 N., R. 3 W., INCLUDING CASA SALAZAR}

The Rio Puerco flows southward across the eastern part of T. $15 \mathrm{~N}$., R. $3 \mathrm{~W}$. With the exception of several dikes and plugs, the Mancos shale is the surface formation throughout the township. In the west face of Mesa Prieta near Casa Salazar, the strike is about N. $30^{\circ}$ E., and the dip $3^{\circ}$ to $4^{\circ} \mathrm{SE}$.; the strike changes to N. $20^{\circ} \mathrm{W}$. south of Cerro Cochino and to N. $50^{\circ} \mathrm{W}$. about a mile northeast of Cerro Cochino. West of the Rio Puerco in the vicinity of Casa Salazar the strike is about N. $35^{\circ} \mathrm{E}$. and the dip $4^{\circ}$ to $6^{\circ} \mathrm{NW}$; the 
strike changes to N. $20^{\circ}$ W. between Guadalupe and Casa Salazar. There is thus a plunging anticline, here called the Guadalupe anticline, which in a general way conforms in trend to the channel of the Rio Puerco, the northern termination being near Guadalupe. The southern tier of sections in this township was not visited, so it is not known whether this anticline closes at the south.

In general the water obtained from shallow dug wells along the Rio Puerco is of inferior quality. The Dakota (?) sandstone, which underlies the valley of the Rio Puerco in this township, is probably about 1,500 feet below the surface and is doubtless water bearing, but it may not yield flowing wells in this township.

At the village of Guadalupe, in the Ignacio Chaves grant, part of which extends into this township, there is a spring of good water.

\section{T. 15 N., R. 2 W.}

Mesa Prieta extends from north to south across T. 15 N., R. 2 W. The mesa is capped with basalt; elsewhere in the township the Mancos shale is at the surface. On the east side of the mesa the rocks, dip west, and on the west side they dip east; thus the sedimentary rocks underlying the mesa form a syncline, and the basalt apparently rests in the synclinal basin.

In the SE: $1 / 4$ NE. $1 / 4$ sec. 24 , T. 15 N., R. 2 W., in the flat near the head of Arroyo Bernalillito, on J. W. Ash's ranch, there is a well about 286 feet deep, with the water standing about 150 feet below the surface. Mr. Hugh M. Bryan reports that this well can be pumped for 40-minute periods about five times daily and that enough water can be obtained to water about 75 head of cattle. The water is highly mineralized and of poor quality for domestic use. A deposit of white alkali was noted over the water troughs. This well apparently derives its water from one of the sandstones in the lower part of the Mancos shale. It is probable that if the well were deepened 100 feet or so it would penetrate the Dakota (?) sandstone and yield water satisfactory for most uses; in that event the water obtained from the Mancos shale should be cased off. Near the head of Arroyo Bernalillito there are several springs of pleasant-tasting water which comes from the Dakota (?) sandstone.

East of Mesa Prieta, in the eastern part of this township, supplies of potable water can probably be obtained by drilling to the Dakota (?) sandstone, which in most places can be reached at a depth of not more than 500 feet, perhaps less.

\section{T. 15 N., R. 1 w.}

T. 15 N., R. 1 W., is drained by Arroyo Bernalillito and its tributary arroyos La Jara, La Carencia, Los Posos, and Cucho. Arroyo Bernalillito empties into the Rio Salado. There are four formations 
exposed in this township. The Todilto formation comes to the surface in secs. 12 and 13. The Morrison formation crops out in the northeastern and central parts of the township, and the erosion of the alternating beds of hard sandstone and soft shale in this formation has given rise to a very rough, dissected, semibadland topography. (See pl. 5, B.) The Dakota (?) sandstone, which is thin here, generally has a very narrow outcrop and is seen mostly in bluffs. The topography produced by the Mancos shale is relatively smooth, but a massive cliff-making sandstone in the lower part of the formation forms a gently westward-sloping mesa in the western part of the township.

In the southern part of sec. 16 , near the center of the south line, on the ranch of Hugh $M$. Bryan, there are two springs, the water of which is used for domestic purposes and for stock. The pool of water at one of these springs is in the Morrison formation, but as the basal bed of the Dakota (?) sandstone is only about 3 feet above, it is almost certain that the water is contributed by the Dakota (?). In the northern part of sec. 22 there are four more springs. Mr. Bryan estimates that the combined yield of these six springs averages 100 gallons a minute.

In the SW. $1 / 4$ sec. 32, J. W. Ash has a well 346 feet deep and 6 inches in diameter. The water level in this well is unknown, but it is reported that 24 hours of pumping with a gasoline engine produces no appreciable drawdown. The water, though satisfactory for stock, is highly mineralized and nonpotable; it probably comes from a sandstone near the base of the Mancos shale. If this well were deepened to the Dakota (?) sandstone and the overlying water cased off a satisfactory supply of potable water could probably be obtained. Wells drilled to the Dakota (?) sandstone at other localities in the western part of this township should yield potable water.

In the eastern part of sec. 14, in the valley of Arroyo Cucho, there is a hole that generally contains water; it is used to some extent for watering stock.

\section{T. 15 N., R. 1 E.}

The Rio Salado and its tributaries drain the northern part of T. 15 N., R. 1 E., and Arroyo Piedra Parada, a tributary of Jemez Creek, drains the southern part. Mesa Blanca, capped with the white gypsum of the Todilto formation, is a prominent topographic feature. (See pl. 5, A.) South of Mesa Blanca the Morrison formation, Dakota (?) sandstone, Mancos shale, Nacimiento group, and Santa Fe formation crop out in succession. In the bluffs of Mesa Blanca the Wingate sandstone and the Chinle (?) formation are 
exposed below the Todilto. The Chinle (?) is exposed also north of the Rio Salado. The rocks in the-central part of the township have been considerably deformed by folding and faulting.

The San Ysidro Springs, in the northern part of the township, are described on pages 86-87. These springs issue mostly in the area of outcrop of the Chinle (?) formation, and their water is highly mineralized. (See pl. $8, B$.)

The Dakota (?) sandstone and the Morrison formation dip southward from Mesa Blanca, and it is almost certain that supplies of ground water can be obtained in the valley of Arroyo Piedra Parada by drilling a few hundred feet to the Dakota (?) sandstone and possibly into the Morrison formation. It is probable that artesian flows may be obtained in the lower part of this valley. Conditions are similar in the valley east of the fault in secs. 29 and 32, and the Dakota (?) sandstone here may yield supplies of water. Water obtained from the Dakota (?) at either of these localities will doubtless be under artesian pressure and rise in the well. In the valley of Canada de las Milpas, in the tract embracing the SW. $1 / 4$ sec. 8, SE. $1 / 4$ sec. 7 , W. $1 / 2$ W. $1 / 2$ sec. 17 , and E. $1 / 2$ E. $1 / 2$ sec. 18 , which is within a synclinal basin, supplies of water might be obtained by drilling into the sandstones of the Morrison formation, which underlie this valley. If water is obtained it will probably rise in the wells and might even overflow.

T. 14 N., R. 1 W.

Only the northeastern part of T. 14 N., R. 1 W., was visited. Along the contact with the Mancos shale the overlying Nacimiento beds dip southeastward and at some places are nearly vertical. The Santa Fe formation is at the surface in the southeastern part of the township.

Water supplies can doubtless be obtained by drilling through the Mancos shale into the Dakota (?) sandstone, and such drilling is feasible in the northeastern part of the township, as the Mancos shale here is apparently thinner than it is on the north.

It can not be predicted with certainty whether or not supplies of water may be obtained by drilling wells into the Santa Fe formation. At some localities good water has been obtained from this formation, and at others only meager supplies of poor water. The question of the desirability of drilling into the Santa Fe as a waterbearing formation is discussed on pages $41-42$. The rocks of the Nacimiento group in this township will probably yield supplies of water, but the quality to be expected is uncertain. 


\section{T. 14 N., R. 1 E.}

In the northern part of T. 14 N., R. 1 E., the Mancos shale, the Nacimiento group, and the Wasatch formation are at the surface; in the central and southern parts the Santa Fe formation is at the surface. In the northern part the beds are displaced by three major faults-the Jemez and Sierrita faults, which extend along the east side of the Sierra Nacimiento, and the Canada de las Milpas fault, which extends along the west side. These faults have undoubtedly displaced the Santa Fe to some extent. Their southern continuation has not been mapped; they probably extend farther than is shown on Plate 1 . The rough topography in the southeastern part of the township probably represents the southern continuation of the Jemez fault and possibly the Sierrita fault.

In the northwestern part of this township, where the Mancos is at the surface, water supplies can probably be obtained within several hundred feet of the surface by drilling to the Dakota (?) sandstone. The water-bearing character of the rocks of the Nacimiento group in this area is not well established, but it is probable that the sandstones and coal beds of this group will yield water. La Ceja, in the southern part of the township stands considerably above the surrounding surface. Here it is probably several hundred feet to water, and any supplies of ground water that might be obtained at reasonable depth would be derived from the Santa Fe or the Wasatch formation.

\section{T. 14 N., R. 2 E.}

T. 14 N., R. 2 E., includes a part of La Ceja, and the entire township is much dissected by streams flowing to Jemez Creek and the Rio Grande. The Santa Fe is the surface formation. There are apparently no wells in this township, and there are few data on which to base an opinion as to ground-water conditions. The water table is no doubt several hundred feet below the surface, but the Santa Fe formation, at a depth of 500 feet or less, will probably yield water.

\section{T. 13 N., R. 3 E.}

In T. 13 N., R. 3 E., the Santa Fe formation is at the surface except in the southeastern part, where near the Rio Grande there are younger terrace deposits and Recent alluvium. Supplies of water can be obtained by sinking shallow wells into the alluvium in the eastern part of sec. 36 , where the ground-water conditions are similar to those in the vicinity of Bernalillo. (See p. 114.)

In the southeastern part of the township, in the vicinity of the Rio Grande, the water table is relatively near the surface, but on the higher ground in the northwestern part it will doubtless be necessary to drill to greater depths. 


\section{INDIAN PUEBLO GRANTS AND RESERVATIONS}

Included in the area described in this report are three Indian pueblos-the Jemez, Santa Ana, and Sia. The Jemez Indians are the only ones that have increased in numbers since 1805, when the first accurate census was taken.

Population of pueblos in parts of Sandoval County covered by this report

\begin{tabular}{|c|c|c|c|c|}
\hline & 1805 & 1900 & 1912 & 1925 \\
\hline $\begin{array}{l}\text { Jemez } \\
\text { Santa Ana } \\
\text { Sia }\end{array}$ & $\begin{array}{l}264 \\
450 \\
254\end{array}$ & $\begin{array}{l}455 \\
228 \\
116\end{array}$ & $\begin{array}{l}555 \\
221 \\
118\end{array}$ & $\begin{array}{l}603 \\
224 \\
157\end{array}$ \\
\hline
\end{tabular}

JEMEZ PUEBLO AND T. 16 N., R. 2 E.

The Jemez Pueblo contains about 17,510 acres and includes most of what would be T. 16 N., R. 2 E. The grant is drained by Jemez Creek. In the western part of the grant the Jemez fault, which trends northeast, complicates the geologic structure. (See pl. 1.) The limestone of the Magdalena group crops out over several square miles in the northwest corner, and the Abo sandstone, Chupadera formation, and part of the Poelo sandstone are well exposed in cliff sections. In the northeast corner of the grant there are several faults that trend northwest; in proximity to these faults the Abo sandstone, Chupadera formation, and basal beds of Poleo sandstone are exposed. The Santa $\mathrm{Fe}$ is the principal surface formation, and in this locality it consists mostly of sand with little conglomerate.. A broad tract of alluvium borders Jemez Creek.

The Jemez Indians irrigate the bottom land adjacent to Jemez Creek, and are very successful in raising crops of hay, grain, beans, potatoes, truck, and fruit. It is estimated that they have about 3,000 acres under cultivation. There are two ditches for diverting the water from Jemez Creek, and these ditches are said to have been constructed before the white man came to this country.

The United States Indian Service has drilled several wells at and in the vicinity of Jemez, which are listed below. Although the table gives the appearance of a considerable proportion of dry holes, most of the holes were abandoned at depths of less than 100 feet, generally because of some mechanical difficulty or because of encountering hard sandstone. The surface of the ground upon which the pueblo is built slopes westward, and the eastern part of the village is therefore at a higher altitude. The variation in depth to water is due in part to this slope and may also be due in part to the presence of faults, the exact relations of which are obscured by cover of alluvium and terrace deposits. 
Wells in the vicinity of Jemez

[All wells are 6 inches in diameter. Wells 815 to 819 were drilled in 1921 , wells 820 to 828 in 1922 ; the date of 829 is not known]

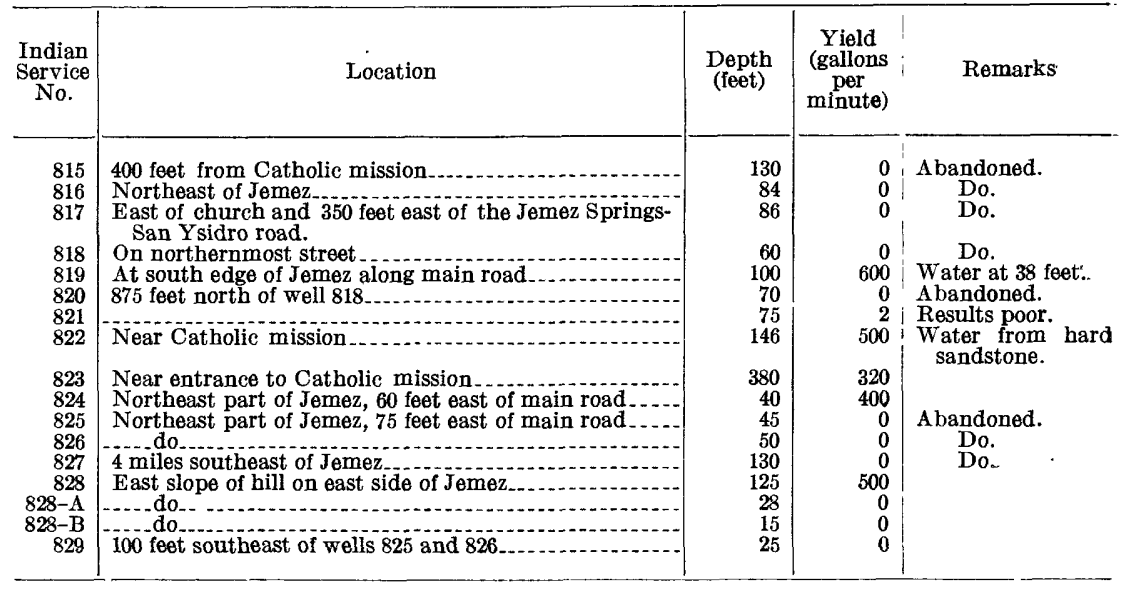

The water from these wells is potable and pleasant tasting. The water of well 819 , which is 100 feet deep, though hard, contains only about 628 parts per million of total dissolved solids (see analysis 7 , p. 78) ; that of well 828 , which is 125 feet deep, is of similar composition and contains only 700 parts per million of dissolved solids. (see analysis 8 ). The water from these wells is used for all domestic purposes and for stock. Prior to the construction of these wells: the water from Jemez Creek was used by the Indians for all purposes. There are springs along certain of the faults in the southwestern part of the grant, but in general the water is highly mineralized. These are the so-called Indian Springs described on page 86.

JEMEZ INDIAN RESERVATION AND T. 16 N., R. 1 E.

West of the Jemez Pueblo grant is the Jemez Indian Reservation, a tract of land embracing most of T. 16 N., R. 1 E. The reservation contains 23,040 acres and was set aside by Executive orders of December 19, 1906, and September 1, 1911. It includes the rough, dissected country at the south end of the Sierra Nacimiento. The structure is complicated by faulting, and the geologic section includes rocks from the pre-Cambrian to the Triassic Poleo sandstone.

Along the faults near the east and west sides of the reservation there are springs of highly mineralized water. Those of the west group have been described as the Phillips Springs. (See pp. 87-88.) The Jemez Indians gather a considerable amount of piñon anit cedar for firewood from this reservation, and they also utilize the reservation to some extent for grazing. 
SIA PUEBLO AND T. 15 N., R. 2 E.

The Sia Pueblo grant includes the major part of T. 15 N., R. 2 E., and the northern tier of sections in T. 14 N., R. 2 E. Jemez Creek flows diagonally southeastward across this grant. Its channel is about a quarter of a mile wide but in most places is sandy. Most of the water of Jemez Creek is diverted farther upstream by the Jemez Indians and by the residents of San Ysidro, and the Rio Salado generally contributes little. Owing to the scanty supply of water the Sia Indians have only about 450 acres under ditch, an amount insufficient to furnish their food. Facilities for the irrigation of additional land are being installed.

The United States Indian Service in 1922 drilled three wells at Sia, each 100 feet deep. They yield 350,600, and 1,000 gallons a minute. All three of these wells are in the Santa Fe formation, probably for their entire depth, and the water must come from some gravel or sand bed in the Santa Fe. The water is probably similar in chemical character to that in the well south of Santa Ana, which, though potable and pleasant-tasting, is hard.

In general, water may be obtained within a few hundred feet of the surface by drilling wells along the valley of Jemez Creek in this township. Such water will be hard.

The history of the Sia Indians is described in a report by Matilda C. Stevenson. ${ }^{98}$

SANTA ANA PUEBLO AND T. 14 N., R. 3 E.

The Santa Ana Pueblo grant includes most of T. 14 N., R. 3 E. Jemez Creek flows southeastward across this township. Its channel is filled with silt, sand, and some gravel, and in places it is almost half a mile wide. In this channel there is generally only a very small stream of water, except after heavy rains. In proximity to the channel at many places there are deposits of wind-blown sand. The Santa Fe formation is at the surface over most of the remainder of the township, and a considerable section of this formation is well displayed in the bluff below Santa Ana Mesa. Several flows of black basalt cap Santa Ana Mesa, and at some places in the bluff below the basalt cap there are dikes that were presumably feeders to the overlying flows.

The United States Indian Service has drilled two wells each about 30 feet deep in the vicinity of Santa Ana. A sample was collected from one of these wells, which is about 200 yards south of the pueblo and is 6 inches in diameter. The water has a pleasant taste, and

Stevenson, M. C., The Sia : Bur. Am. Ethnology Eleventh Ann. Rept., pp. 9-157, 1894. 
an analysis (see No. 9, p. 78) shows that though hard it contains only about 933 parts per million of dissolved solids, which is not excessive for this region. Jemez Creek in all probability has considerable underflow, and it is very probable that supplies of ground water can be obtained by sinking wells into the alluvium at almost any place along the flood plain of the stream in this township. A way from the river, where the surface is higher, the water table is deeper and it would probably be necessary to drill several hundred feet in order to obtain water.

\section{SANTA ANA RANCHITOS}

The Santa Ana ranchitos, or El Ranchito grant, lies along the Rio Grande south of the mouth of Jemez Creek and north of the Bernalillo grant. The Santa Ana Indians, with considerable foresight, evidently realized a great many years ago that in order for them to prosper it was necessary to have more agricultural land, and they accordingly purchased this tract including the fertile land along the flood plain of the Rio Grande. The grant embraces about 4,945 acres in T. 13 N., R. 4 E., and was confirmed by the United States Land Court in 1899; it is adequate for the needs of the Santa Ana Pueblo. At the present time only about 750 acres is under cultivation, but if in the future it is desired to irrigate additional land the Rio Grande is an adequate source of water. The Santa Ana Indians spend the summer down on the river at the ranchitos cultivating their crops and leave only one or two men to watch the pueblo. Like the Jemez Indians, they are able to raise enough to provide for their needs.

Several wells have been drilled at the Santa Ana ranchitos by the Indian Service. One is 30 feet deep, and is capable of yielding 600 gallons a minute; another is 33 feet deep and yields 1,000 gallons a minute. In general the ground-water conditions along the Rio Grande are similar to those in the Bernalillo grant, and groundwater supplies may be obtained within a few feet of the surface at almost any place along the flood plain of the river.

\section{LAND GRANTS OTHER THAN THOSE MADE TO THE INDIANS}

\section{OJO DEL ESPIRITU SANTO GRANT}

The largest grant in this region is the Ojo del Espiritu Santo grant (see pl. 1), which embraces an area of more than 100,000 acres, including all of what would be T. 18 N., R. 1 W.; T. 17 N., R. 1 W.; T. 16 N., R. 2 W.; T. 16 N., R. 1 W., and small parts of several adjacent townships. The Sierra Nacimiento parallels this grant on the east and is partly within it. Pre-Cambrian granite, which forms 
the core of the range, is well exposed along the east side of the grant. The Paleozoic and Mesozoic sedimentary rocks, which are upturned along the western front of the mountains, give rise to a series of ridges or hogbacks. The topography in the eastern part of the grant is rough, but west of the foothills in the northern part of the grant, where the Mancos shale is at the surface, it is undulating. In the southern part of the grant, west of the mountains, where the rocks below the Dakota (?) sandstone (Morrison, Todilto, Wingate, and Chinle (?) formations) are at the surface, the erosion of the alternating hard and soft beds has resulted in a rough, dissected topography.

The Rio Puerco forms the northwest boundary of this grant and with its tributaries Arroyo de Dos Gordos and Arroyo Olguin drains the northern part of it; the Rio Salado and its tributaries, Arroyo Penasco, Arroyo Chachuile, Arroyo Lopez, and Rito Semilla, drain the southern part. The Rio Salado is tributary to Jemez Creek.

The ground-water conditions in different parts of the Ojo del Espiritu Santo grant differ considerably because of the diversity in geologic structure, topography, and character of the rocks. In the northern part of the grant, where the Mancos shale is at the surface, the Dakota (?) sandstone is the most satisfactory aquifer. There is a spring near the ranch house with a yield of about 2 gallons a minute, and although the water comes from alluvium along a tributary to the Rito Semilla, it is almost certain that the Dakota (?) sandstone, which crops out a few hundred feet to the east, contributes the water. An analysis of the water (No. 5, p. 78) shows that though hard, it contains only about 396 parts per million of dissolved solids. This water has a pleasant taste and is used for domestic purposes and for stock. There is a spring of larger yield a little more than a mile to the north, the water of which comes from the alluvium along Arroyo Lopez. North of the latitude of Los Bancos, the valleys of the Rio Puerco and Arroyo Chachulie are regarded as prospective areas for testing the artesian conditions of the Dakota (?) sandstone and the underlying Morrison formation, but flows are not assured. (See p. 85.)

A short time before the completion of this investigation a well was begun with a view to testing the oil-bearing possibilities of the La Ventana anticline. A log of this well is found on page 39, and R. A. Conklin, geologist, reports that "there was a hole full of water from a depth of 1,650 feet on down, so that they were not able to keep. samples." It was reported that the water came within 150 feet of the surface. The water-bearing sandstone at 1,650 feet was probably one of the sandstones in the lower part of the Mancos shale. 
West of Los Bancos the Dakota (?) sandstone is within a few feet of the surface, but northward the amount of the Mancos overlying the Dakota (?) sandstone gradually increases, and near La Ventana it will be necessary to drill through almost the entire Mancos section before the Dakota (?) sandstone is reached. At several places along the east side of the grant the sandstones in the lower part of the Mancos give rise to small seeps and springs. It is reported that about $61 / 2$ miles west of Los Bancos there is a group of springs known as Los Ojitos Springs. These were not visited, but it is evident from the location that the water comes from the Mancos, and it is probably derived from one of the sandstones in that formation. West of the Dakota (?) outcrop, in the southwestern part of the grant, water supplies may be obtained by drilling to the Dakota (?) sandstone, but flowing wells are not to be expected. It is also probable that in this tract, as well as farther north in the grant, the sandstones in the Mancos will yield supplies of ground water, but it is possible that such water will be mineralized and of less satisfactory quality than the water in the underlying Dakota (?) sandstone. In general, only meager supplies of poor water are obtained from shallow dug wells in the Mancos shale, but the alluvium along the Rio Puerco yields water which is somewhat mineralized but fairly satisfactory for drinking and for stock.

East of the Dakota (?) outcrop, where the country is broken and dissected and the underlying formations are exposed, the groundwater conditions are variable. Along the mountain front in the northern part of the grant, there are seeps and small springs in most of the canyons. It is entirely probable that the Dakota (?) and Morrison formations in the southern part of the grant give rise to seeps and small springs, but none were located.

Along the Rio Salado most of the shallow ground water will probably be found to be highly mineralized because of the proximity of the. gypsum of the Todilto formation. There is an abundant stand of greasewood along the Rio Penasco, and these plants indicate that shallow ground water is to be expected along this stream, which is fed by numerous springs adjacent to the mountain. The large supplies of artesian water obtained from the Kaseman wells Nos. 1 and 2 along Arroyo Cachana in the southern part of the grant are described on pages $82-83$.

\section{SAN YSIDRO GRANT}

The San Ysidro grant occupies what would be the southern part of T. 16 N., Rs. 1 and 2 E., the northern part of T. 15 N., Rs. 1 and 2 E., and the northwest corner of T. 15 N., R. 3 E. This grant 
is about 11 miles long and about $13 / 4$ miles wide. The homes that comprise the community of San Ysidro are located along the highway from Bernalillo and Albuquerque, which forks at the south end of the village, one road going to Cuba and the other to Jemez Springs and :Sulphur Springs. In the western half of this grant the geologic structure is complicated by the Sierra Nacimiento overthrust, the Jemez fault, and the Sierrita fault. The strip of country along the Rio Salado for a mile or more west of the Sierrita fault and extending to the Sierra Nacimiento fault is within the tract that is regarded as favorable for prospecting for flowing wells.

East of the faulted belt the surface structure is simple, the Santa Fe being the surface formation throughout the eastern part of the grant, except for a cap of Tertiary rhyolite on the Cerrito Negro and the alluvium along Jemez Creek.

Potable but hard water may be obtained by digging shallow wells 12 to 20 feet deep in the alluvium along the Jemez Creek. A sample cf water from a well of this type was collected from J. W. Miller's ranch at San Ysidro. The well is 13 feet deep and 3.5 feet in diameter. Analysis 6 (p. 78) shows that the water, though hard, contains only 693 parts per million of total dissolved solids. This water is pleasant tasting and may be regarded as an index of the character of water that is to be expected in the alluvium along Jemez Creek. Water obtained from shallow wells in the alluvium along the Rio Salado will in all probability be similar in quality to the surface water in the Rio Salado, which is more highly mineralized than that along Jemez Creek, so much so that some stock refuse to drink it.

\section{IGNACIO CHAVES GRANT, INCLUDING GUADALUPE}

The Ignacio Chaves grant extends west from the Rio Puerco for :several miles in a strip that includes the southwest corner of T. $16 \mathrm{~N}$, R. $3 \mathrm{~W}$., and the northwest corner of T. 15 N., R. $3 \mathrm{~W}$. The Mancos shale is the surface formation throughout that part of the grant shown on Plate 1, except for several plugs of basalt, the most prominent of which are Cerro de las Chanisalas and El Salado. The village of Guadalupe is on the west side of the Rio Puerco in the southern part of the grant. At Guadalupe there is a spring of satisfactory water with an estimated yield of a gallon a minute. This water comes to the surface out of the Mancos shale along what is apparently a small fault, but it is so far superior to any other water that occurs in the Mancos that it is reasonable to assume that it may come from the Dakota (?) sandstone, which may be closer to the surface along this fault than usual. Water from this spring is hauled for domestic use for considerable distances by some of the inhabitants of 
the Rio Puerco Valley. Ground water may also be obtained from shallow wells dug into the alluvium along the Rio Grande, but the quality of such water for domestic use is questionable.

\section{BERNALILLO GRANT}

The Bernalillo (Felipe Gutiérrez) grant is in what would be the southern part of T. 13 N., R. 4 E. The town of Bernalillo is about a mile east of the Rio Grande, near the central part of the grant. It is on the flood plain of the Rio Grande and is underlain by good water-bearing gravel. The White Pine Lumber Co. has three wells between the town and the river, in all of which the water stands about 5 feet below the surface. Two of these wells are 8 inches in diameter and between 65 and 70 feet deep. Each has a plunger-type pump with a capacity of 135 gallons a minute, and it is reported that either may be pumped continuously without being pumped dry. The third well is 14 feet in diameter and 16 feet deep and is equipped with a pump that has a capacity of 750 gallons a minute, which is to be used only in case of fire. During the digging of this well the company endeavored to pump it dry with a centrifugal pump working constantly but was unable to do so. Analysis 10 (p. 78), representing the water of this well, shows that it contains 782 parts per million of total dissolved solids and has a hardness of 274 parts per million. The water is potable, and the taste is fair.

In the center of Bernalillo the Putney Mercantile Co. has a driven well 60 feet deep; the water is hard and has a slightly alkaline taste. There are a number of other shallow wells in the vicinity of Bernalillo; in most of them the water level is 5 to 10 feet below the surface. The gravel underlying the town contains an adequate supply of hard water-a condition which also prevails along the flooded plain of the Rio Grande throughout this area. It is uncertain whether supplies of soft water could be obtained by drilling deeper. 


\section{INDEX}

\begin{tabular}{|c|c|}
\hline $\mathbf{P a}$ & 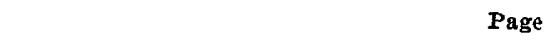 \\
\hline $\mathbf{A}$ & Cliunate, features of \\
\hline bo sandstone, features of & Conlisk, G. E., well of, analysis of water of.- 78 \\
\hline section of & Cretaceous rocks, features of \\
\hline -........ & Cretaceous (?) rocks, features of $\ldots \ldots \ldots$ \\
\hline cknowledginents for aid........ & Cuba, ground water at. \\
\hline griculture & wells in, analyses of water of \\
\hline Huvium, occurrence of $63-64$ & \\
\hline 64 & Dolote (9) andatome fonturoe of $25-2$ \\
\hline -............... & Dakota (?) sandstone, features of \\
\hline $\begin{array}{l}\text { roin Sandoval County.-. } \\
\text { lley, area of artesian flow }\end{array}$ & $\begin{array}{l}\text { sections of } \\
\text { specific gravity and porosity of }\end{array}$ \\
\hline in. & water in \\
\hline Arroyo Piedra Lumbre, artesian conditions & lysis of \\
\hline (50) & Deformation, age of \\
\hline Arroyo Piedra Parada, artesian conditions in. & Drainage, features of \\
\hline Iitions, general principles of & 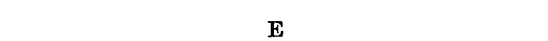 \\
\hline $\begin{array}{l}\text { Artesian flow, areas of } \\
\text { Ash, O. K., spring owned by, analysis of }\end{array}$ & Eocene rocks, features of \\
\hline water of & $\mathbf{F}$ \\
\hline $\mathbf{B}$ & Fairchild, J. G., analyses' by ................... \\
\hline ence of & f. \\
\hline - n......... & $1-3$ \\
\hline of......... & Folds, occurrence and character of \\
\hline Ind water & Foster, M. D., analysis of water by \\
\hline Botkin, C. W., analyses of water by & 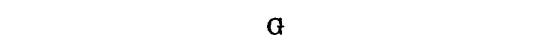 \\
\hline $\mathbf{0}$ & Gardner, J. H., quoted............. \\
\hline & aters........ 8 \\
\hline (n) & cket), \\
\hline 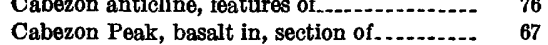 & $\ldots 16-17$ \\
\hline$\ldots$ & h-level, features \\
\hline ns in. & \\
\hline of.-.- & \\
\hline s of............ & -81 \\
\hline 75 & \\
\hline vatures of & in \\
\hline $102-103$ & Guadalupe, groundwater in \\
\hline & Guadalupe anticline, features of \\
\hline 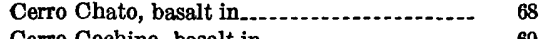 & \\
\hline - & $\mathbf{H}$ \\
\hline$\ldots$ & History of investigation. \\
\hline asalt in. & Howard, C. S., analyses of water by \\
\hline -........... & \\
\hline litions in ..... & I \\
\hline , with & ves grant, ground \\
\hline 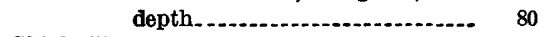 & is rocks, features of \\
\hline n, features of & $\begin{array}{l}\text { Indian pueblo grants and reservations, } \\
\text { ground water in }\end{array}$ \\
\hline water in.- & Indian Springs, features of \\
\hline Chupadera for & 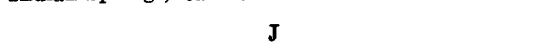 \\
\hline 20 & ear..... \\
\hline r] & \\
\hline & lysis of water of \\
\hline water i & Jeinez fault, features of \\
\hline
\end{tabular}


Page

Jemez Indian Reservation, ground water in. 108 Jemez Pueblo, ground water in.......... 107-108 Jemez Springs, analysis of water of......... 78 Johnson, D. W., quoted .............. 68-69 Jurassic (?) rocks, features of ............. 29-32

\section{K}

Kaseman well No. 1, water of, analysis of.... Kaseman well No. 2, $\log$ of. water of, analyses of

Kennedy, H. S., test for helium by

\section{$\mathbf{L}$}

La Abra de los Cerros, basalt in.

Lo Sierrito faults at north end of fotures of

Le Ventana, well at $\log$ of

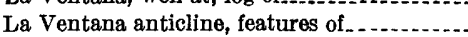

Lew is shale, features of $\quad 40-50$

fossils in

water in .............................. 50

Location and general configuration of area... $3-5$

\section{M}

Magdalena group, features of............... 13-17 fossils of . section of water in ............................ 17

Mancos shale, features of $39-43$ fossils of .................................. 41 section of ................................ 40 water in

Map, geologic, of western part of Sandoval County .............. pl. 1 (in pocket)

Mesa Blanca, view of................ 5

Mesa Chivato, basalt in

Mesa Prieta, basalt in ...................... 66

Mesaverde formation, coal in ............. 48-49 coal in, analyses of ...................... 49 features of ............................... 43-49 sections of . . specific gravity and porosity of rock of... $\quad 35$ view showing water in

analysis of

Milligram equivalent, formula for obtaining $\quad 78$ Miocene and Pliocene rocks, features of...... 56-59

Morrison formation, features of . . . . . section of................................ 33-34 specific gravity and porosity of sandstone

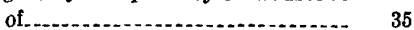
view showing lower part of ............ pl. 5

\section{$\mathbf{N}$}

Nacimiento group, features of................. 50-53 section of . view showing water in

Newberry, J. S., quoted.

\section{O}

Ojo del Espiritu Santo grant, ground water in . . 110-112 wells on, features of................. 82-83 analysis of water of ............. olguin anticline, features of ............. $75-76$;

\section{$\mathbf{P}$}

Pediment deposits, water in ............. $62^{*}$

Pediments, occurrence of . .

Pennsylvanian rocks, features of............ 13-17

Permian series, general relations of .......... 17-18

Phillips Springs, features of .................. 87-88

Plants as indicators of ground water........ 89-90.

Pleistocene deposits, features of.............. 59-63.

Poleo hogback, panorama from ............. pl. 4

Poleo sandstone, analysis of . . . . . .

features of . $24-26$

sections of

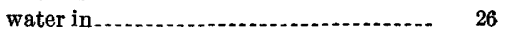

Pre-Cambrian rocks, features of . . . . . . ..... 12-13 water in ............ 13

Puerco formation, features of . . . . . . . . . . . 50-53

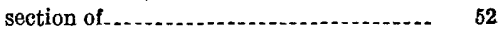
water in........... 53 analysis of 78

\section{Q}

Quality of ground water........................ 77-81

relation of, to use ...................... 80

Quaternary deposits, features of ............ 59-64

\section{$\mathbf{R}$}

Railroads and roads. ......................... 10-11

Recent deposits, features of................... 63-64

Reeside, J. B., jr., fossils identified by ....... 41, 50

Rhyolite and rhyolite tuff, occurrence of...... 69-70 water in .............................

Riffenburg, H. B., analyses of water by ..... 78 .

Rio Puerco Valley, artesian conditions in... $\quad 85$. basalt in lower.............................. 66 -69.

Rio Salado, analysis of water of.............. 78 .

Rio Salado anticline, features of ............ 76 south end of................................ pl.

Rio Salado Valley, artesian conditions in.... $\quad 85$.

$$
\mathrm{S}
$$

Sandoval County, geologic map and sections of western part of ..... pl. 1 (in pocket) rock formations in, and their waterbearing properties................ 12 water analyses from. ................. 78 graphic representation of ............. pl. 8 San Jose-Puerco Valley, artesian conditions in .................................. 84

Santa Ana, well at, analysis of water of ..... $\quad 78$ Santa Ana Mesa, basalt in ................... 65 . Santa Ana Pueblo grant, ground water in.. 109-110 Santa Ana ranchitos, ground water, at....... 110 
